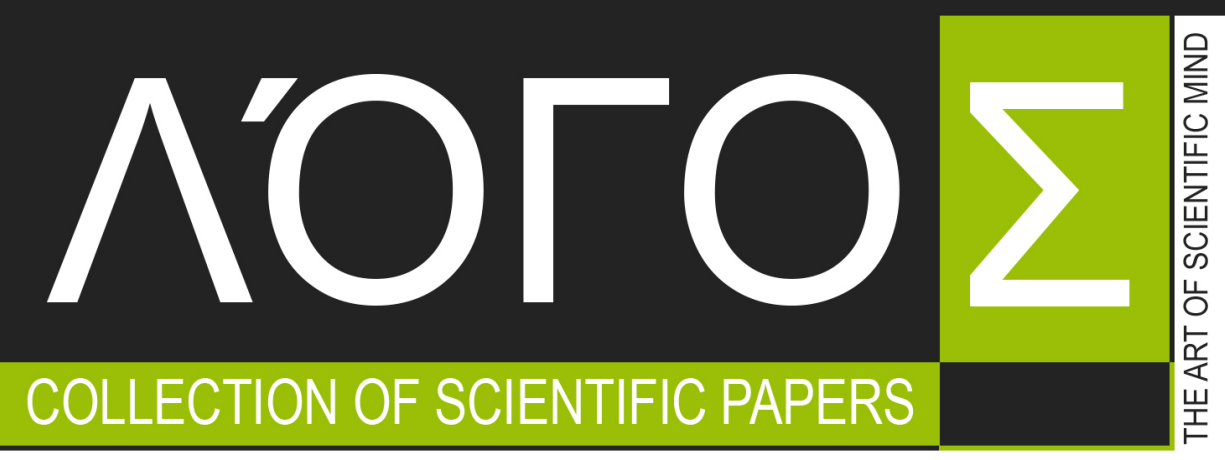

WITH PROCEEDINGS OF THE INTERNATIONAL SCIENTIFIC AND PRACTICAL CONFERENCE

\title{
PROBLEMS AND PROSPECTS OF IMPLEMENTATION OF INNOVATIVE RESEARCH RESULTS
}

DECEMBER 13, $2019 \cdot$ VALLETTA, MALTA

\section{VOLUME 3}

DOI 10.36074/13.12.2019.v3

ISBN 978-617-7171-91-0

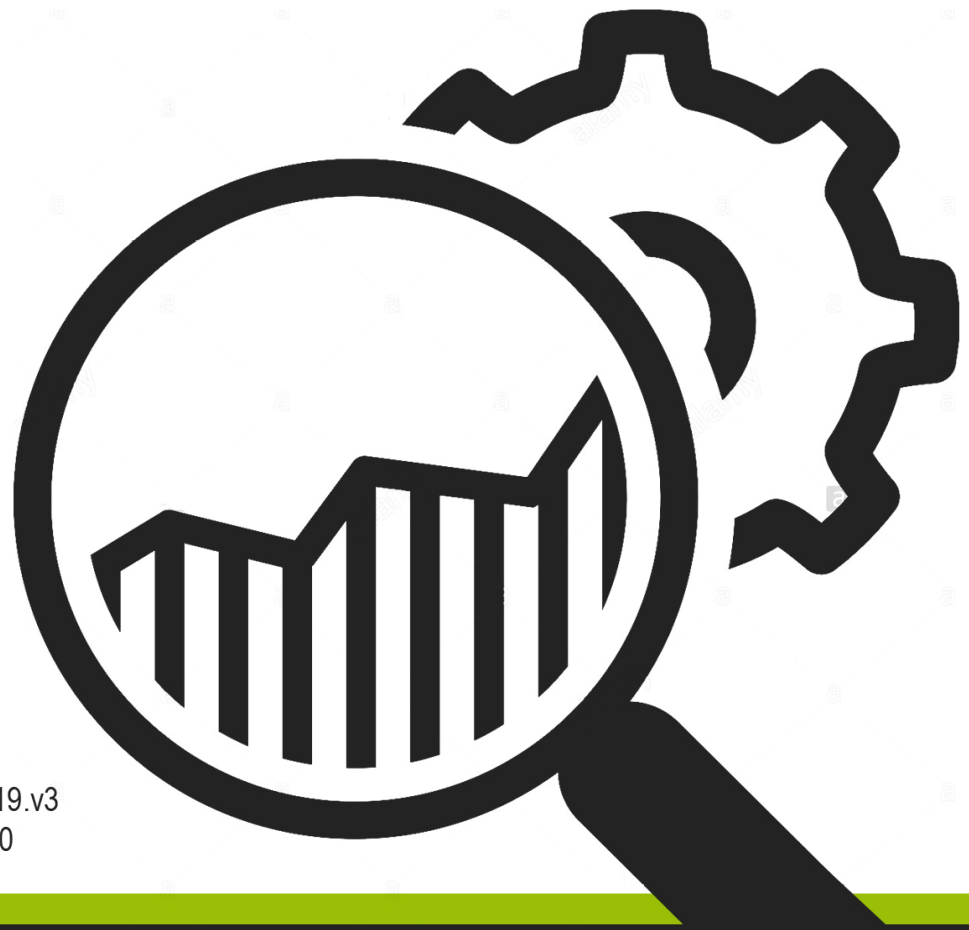



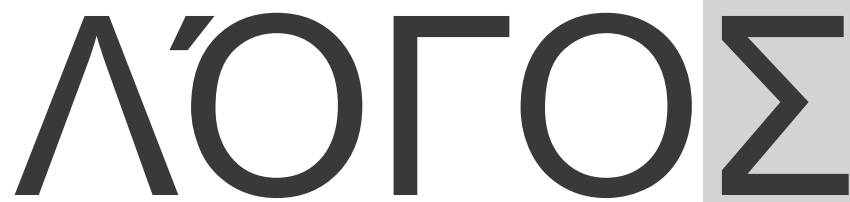

COLLECTION OF SCIENTIFIC PAPERS

WITH PROCEEDINGS OF THE INTERNATIONAL SCIENTIFIC AND PRACTICAL CONFERENCE «PROBLEMS AND PROSPECTS OF IMPLEMENTATION OF INNOVATIVE RESEARCH RESULTS»

DECEMBER 13, 2019

VOLUME 3

Valletta $\bullet$ Republic of Malta 
P 93

Chairman of the Organizing Committee: Holdenblat M.

Responsible for the layout: Kazmina N.

Responsible designer: Bondarenko I.

P 93 Problems and prospects of implementation of innovative research results: collection of scientific papers "А ОГО $\Sigma$ » with Proceedings of the International Scientific and Practical Conference (Vol. 3), December 13, 2019. Valletta, Republic of Malta: European Scientific Platform NGO.

ISBN 978-617-7171-91-0

DOI 10.36074/13.12.2019.v3

Papers of participants of the International Multidisciplinary Scientific and Practical Conference «Problems and prospects of implementation of innovative research results", held in Valletta, December 13, 2019, are presented in the collection of scientific papers.

The conference is included in the catalog of International Scientific Conferences, approved by ResearchBib and certified by Euro Science Certification Group (SCC-2000).

Conference proceedings are publicly available under terms of the Creative Commons Attribution 4.0 International License (CC BY 4.0).

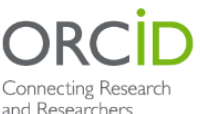

and Researchers

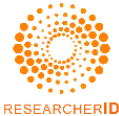

RESEARCHERID
Bibliographic descriptions of the conference proceedings are available for indexation by ORCID, Publons, Google Scholar, ets.

(C) Participants of the conference, 2019 
SECTION VII.

\section{CONTENT}

\section{VETERINARY MEDICINE}

ЕТІОЛОГІЯ, ДІАГНОСТИКА ТА ПРИНЦИПИ ЛІКУВАННЯ КОНЕЙ ЗА ГОСТРОГО ПЕРЕБІГУ АЛЬВЕОЛЯРНОЇ ЕМФІЗЕМИ ЛЕГЕНЬ Камінська К.В., Голопура С.І.

ЗАЛИШКОВА КІЛЬКІСТЬ ПЕСТИЦИДІВ В МЕДІ І ПРОДУКТАХ БДЖІЛЬНИЦТВА

Камінська К.В., Ткачук С.А.

SECTION VIII.

PSYCHOLOGY AND SOCIOLOGY

ESTABLISHING AN UNDERSTANDING SERVICE IN EDUCATIONAL INSTUTIONS AS A GUARANTEE FOR A PEACEFUL RESOLUTION OF CONFLICTS

Shtangret $L$.

PROBLEMS OF GENDER INEQUALITY IN THE LABOR MARKET IN UKRAINE

Fadieieva A., Valentieva A.

КРЕАТИВНСІТЬ, ЛОКУС КОНТРОЛЮ ТА ОСОБЛИВОСТІ ЇХ ЗВ'ЯЗКУ ІЗ СИМПТОМАМИ ДЕПРЕСІЇ В ОСІБ ЮНАЦЬКОГО ВІКУ Ортинська К.В.

ПСИХОЛОГИЧЕСКИЕ ОСОБЕННОСТИ РЕГУЛЯЦИИ СТРЕССА Кернас А.В.

УКРАЇНСЬКА НАРОДНА ІГРАШКА ЯК ЗАСІБ ФОРМУВАННЯ У ДОШКІЛЬНИКІВ ЦІННІСНОГО СТАВЛЕННЯ ДО НАРОДНОЇ КУЛЬТУРИ

Яценко Т.В., Корнєєва Д.С.

SECTION IX.

SOCIAL COMMUNICATIONS AND CULTUROLOGY

АВТОМАТИЗАЦІЯ БІБЛІОТЕЧНО-БІБЛІОГРАФІЧНИХ ПРОЦЕСІВ Малюк О.Ю.

РОЛЬ ІННОВАЦІЙНОЇ СПІВПРАЦІ РЕСТОРАННОГО БІЗНЕСУ ТА КУЛЬТУРНОГО ТУРИЗМУ В ОТРИМАННІ КРЕАТИВНОГО ТУРИСТИЧНОГО ДОСВІДУ

Дичковський С.І., Іванов С.В. 
4 - Problems and prospects of implementation of innovative research results $\bullet$ Volume 3

\section{SECTION X. PEDAGOGY}

CURRENT TRENDS IN GERMAN PRIMARY EDUCATION IN CONTEXT OF PRIMARY SCHOOL REFORM IN UKRAINE

Dzhurylo A.

SOME ASPECTS OF HISTORY OF THE MEDIA LITERACY MOVEMENT IN IN THE UNITED STATES OF AMERICA AND CANADA

Prykhodkina N.

SPECIFICS OF WORK WITH CHILDREN OF PRESCHOOL AGE (IN PARTICULAR AUTISM)

Pigareva V.

TEACHING COMMUNICATIVE GRAMMAR TO FUTURE ENGINEERS

Kotkovets A., Leonova 0.

ВПЛИВ СОЦІАЛЬНИХ МЕРЕЖ НА МОЛОДШИХ ШКОЛЯРІВ

Пекельник І.Ю.

ДЕЯКІ АСПЕКТИ ВИКОРИСТАННЯ ШТУЧНОГО ІНТЕЛЕКТУ

В ГАЛУЗІ ОСВІТИ

Тищенко М.A.

ІНТЕРАКТИВНІ ТЕХНОЛОГІЇ КОЛЕКТИВНО-ГРУПОВОГО НАВЧАННЯ ЯК ЗАСІБ ТВОРЧОГО РОЗВИТКУ

МОЛОДШИХ ШКОЛЯРІВ

Бондар Ю.В.

НЕПЕРЕРВНА ПЕДАГОГІЧНА ОСВІТА ЯК ФІЛОСОФСЬКА КАТЕГОРІЯ

Ходунова В.Л.

ОБУЧЕНИЕ ЧТЕНИЮ ИНОСТРАННЫХ УЧАЩИХСЯ В СИСТЕМЕ РКИ НА НАЧАЛЬНОМ И ПРОДВИНУТОМ ЭТАПАХ

Черненко И.И.

ПЕРЕВЕРНУТЕ НАВЧАННЯ ЯК ЗАСІБ ФОРМУВАННЯ ІНФОРМАЦІЙНО-КОМУНІКАЦІЙНОÏ КОМПЕТЕНТНОСТІ СТУДЕНТІВ КОЛЕДЖІВ

Пальчик 0.O.

ПІЗНАВАЛЬНА АКТИВНІСТЬ ЯК ОСНОВА РОЗВИТКУ ТВОРЧОЇ ДІЯЛЬНОСТІ МАЙБУТНЬОГО ВЧИТЕЛЯ МУЗИЧНОГО МИСТЕЦТВА

Молчанова-Долінко В.О. 
ПРОБЛЕМНІ АСПЕКТІВ НАСТАВНИЦТВА У ПЕДАГОГІЧНОМУ КОЛЕКТИВІ ВИЩОГО ВІЙСЬКОВОГО НАВЧАЛЬНОГО ЗАКЛАДУ

Дзюба П.М.

ПРОЕКТНА ДІЯЛЬНІСТЬ ЯК СПОСІБ ОРГАНІЗАЦІЇ РОБОТИ МОЛОДШИХ ШКОЛЯРІВ НАД ТЕКСТОМ

Шевчук Л.М.

РОЛЬ ЛЕКЦИЙИХ ЗАНЯТЬ З МАТЕМАТИКИ ПРИ НАВЧАННІ СТУДЕНТІВ ІНЖЕНЕРНИХ СПЕЦІАЛЬНОСТЕЙ

Калініна I.M.

РОЛЬ ПЕДАГОГІЧНОЇ ПРАКТИКИ У ПІДГОТОВЦІ СТУДЕНТІВ ДО ПРОФЕСІИНО-ПЕДАГОГІЧНОЇ ДІЯЛЬНОСТІ

Великдан Ю.В.

САМОСТІЙНА РОБОТА СТУДЕНТІВ З ОХОРОНИ ПРАЦІ

Литвин А.

CEPBIC LEARNINGAPPS ЯК ЗАСІБ ОРГАНІЗАЦІЇ ФОРМУВАЛЬНОГО ОЦІНЮВАННЯ

Стечкевич С.О., Стечкевич О.О.

СКРАЙБІНГ У ОРГАНІЗАЦІЇ НАВЧАЛЬНО-ПІЗНАВАЛЬНОЇ ДІЯЛЬНОСТІ ШКОЛЯРІВ 3 XIMІЇ

Бондаренко Т.О.

СПЕЦИФІКА ЗАСТОСУВАННЯ ІНТЕРАКТИВНИХ МЕТОДІВ НАВЧАННЯ

Зубченко Н.O.

ТОЛЕРАНТНІСТЬ ЯК ПРОФЕСІЙНО-ВАЖЛИВА ЯКІСТЬ ПЕДАГОГА ІНКЛЮЗИВНОЇ ОСВІТИ

Фархадова Е.Ш.

ТРАДИЦІЙНІ ФОРМИ НАВЧАННЯ ГОНЧАРСТВУ В ПІВНІЧНОСХІДНІЙ УКРАЇНІ ХІХ - ПОЧАТКУ ХХ СТОЛІТТЯ

Гулей О.В.

ФОРМУВАННЯ ІНДИВІДУАЛЬНОГО СТИЛЮ ПРОФЕСІЙНОЇ ДІЯЛЬНОСТІ МАЙБУТНІХ МЕНЕДЖЕРІВ СОЦІОКУЛЬТУРНОЇ ДІЯЛЬНОСТІ З ВИКОРИСТАННЯМ ТРЕНІНГУ

Сорока О.В., Калаур С.М. 
6 - Problems and prospects of implementation of innovative research results $\bullet$ Volume 3

SECTION XI.

PHILOLOGY

MEDIA LITERACY IN THE EDUCATIONAL PROCESS OF THE 21ST CENTURY

Research group:

Maslavchuk N., Hnenna M., Mazur L.

ВИКОРИСТАННЯ ЧЕН'ЮЙ ДЛЯ ХАРАКТЕРИСТИКИ ПРИНЦИПУ ЗАБЕЗПЕЧЕННЯ ГАРМОНІЙНОГО ТА ВСЕОСЯЖНОГО (和谐包容) РОЗВИТКУ (坚持和谐包容) В КИТАЙСЬКІЙ ІНІЦІАТИВІ «ОДИН ПОЯС - ОДИН ШЛЯХ» (一带一路)

Чернявська О.В., Чернявська О.Д.

ГРАМАТИЧНІ АСПЕКТИ ПЕРЕКЛАДУ МІЖНАРОДНОЇ ДОКУМЕНТАЦІї

Вдовиченко О.O.

ДРАМА АБСУРДУ В НІМЕЦЬКОМОВНІЙ ДРАМАТУРГІЇ: ПРОБЛЕМИ ПОЕТИКИ ТА ПЕРЕКЛАДУ

Тарасюк В.В. .98

КОНОТАТИВИ В МЕДІА-ДИСКУРСІ

Карабахцян А.T.

ОСОБЛИВОСТІ ПЕРЕКЛАДУ ОБСТАВИНИ В ХУДОЖНІЙ ЛІТЕРАТУРІ

Волянюк І.Ю.

ОСОБЛИВОСТІ ПЕРЕКЛАДУ ВЛАСНИХ НАЗВ

Кіщенко А.Ю

СПОСОБИ ПЕРЕКЛАДУ ЗАЧИНІВ І КІНЦІВОК УКРАЇНСЬКИХ НАРОДНИХ КАЗОК

Рудченко Ю.Р., Сітко А.В.

СУЧАСНІ АНГЛІЙСЬКІ НЕОЛОГІЗМИ ТА СПОСОБИ ЇХ ПЕРЕКЛАДУ УКРАЇНСЬКОЮ МОВОЮ Костенко О.Г.

ФРАЗЕОЛОГІЗМИ В ТЕКСТАХ ВИСТУПІВ ГЛАВ ДЕЛЕГАЦІЙ УРСР НА СЕСІЯХ ГЕНЕРАЛЬНОЇ АСАМБЛЕЇ ООН

Канкаш Г.Д. 


\title{
SECTION VII. VETERINARY MEDICINE
}

\section{ЕТІОЛОГІЯ, ДІАГНОСТИКА ТА ПРИНЦИПИ ЛІКУВАННЯ КОНЕЙ ЗА ГОСТРОГО ПЕРЕБІГУ АЛЬВЕОЛЯРНОЇ ЕМФІЗЕМИ ЛЕГЕНЬ}

\begin{abstract}
Камінська Катерина Вячеславівна
студентка 3 курсу, факультет ветеринарної медицини Національний університет біоресурсів і природокористування України

Голопура Сергій Іванович

кандидат ветеринарних наук, доцент Національний університет біоресурсів і природокористування України УКРАЇHA
\end{abstract}

Патологія органів дихання реєструється серед всіх видів тварин, особливо молодняку, і носить найчастіше сезонний характер. Під час ураження органів дихання в організмі погіршується газообмін, що призводить до порушення функцій серцево-судинної, травної, сечовидільної та інших систем. Порушення вентиляції легень клінічно проявляються легеневою недостатністю. Як наслідок, розвивається гіпоксія, тобто, знижується насичення крові і тканин киснем. Це клінічно проявляється сильно вираженою загальною слабкістю, ціанозом слизових оболонок, що може викликати коматозний стан і закінчитися загибеллю тварини.

Емфізема легень (emphysema pulmonum) - захворювання органів дихання, яке характеризується надмірним накопиченням повітря в альвеолах або в інтерстиціальній тканині.

Основними причинами альвеолярної емфіземи легень $є$ надмірне фізичне навантаження у коней або ж тривале звуження верхніх дихальних шляхів, бронхів. Виникненню її сприяють тяжкі приступи кашлю, які часто бувають за хронічного бронхіту. Інколи вона виникає раптово за типом алергічної реакції, яка супроводжується вираженими спазмами бронхів [1]. Альвеолярна емфізема легень супроводжується експіраторною задишкою, швидкою втомою під час роботи або руху. В тяжких випадках задишка буває навіть у стані спокою, з'являється черевний тип дихання. Це часто супроводжується появою «запального жолобу». Під час вдиху, внаслідок посилених екскурсій грудної клітки і зниження еластичності стінок альвеол можливе втягування міжреберних проміжків. Температура тіла в межах фізіологічних коливань або субфебрильна. Кашель глухий, короткий, слабкий. При ускладненні бронхітом кашель стає більш гучним і довготривалим.

За гострої альвеолярної емфіземи легень тваринам забезпечують перебування на свіжому повітрі, повний спокій і призначають лікарські засоби, які регулюють функцію дихальної і серцево-судинної систем [2].

Коням призначають вентипульмін з розрахунку 1 г на 20 кг маси тварини 2 p/добу, або підшкірно вводять 0,1\%-й розчин атропіну сульфату по 10-15 мл 
на ін'єкцію, 5\%-й розчин ефедрину гідрохлориду по 10-15 мл протягом 5-7 днів. За наявності алергічних етіологічних фракторів рекомендують кальцію хлорид, натрію або калію бромід, новокаїн, аміназин, пропазин, піпольфеен, супрастин. В тяжких випадках для контролю над емфіземою застосовують системні кортикостероїди (преднізолон, дексаметазон). Застосовують серцеві й загальнотонізуючі засоби (глюкоза, кофеїн, кордіамін). Якщо альвеолярна емфізема перебігає хронічно, коней, які не мають племінної цінності, вибраковують чи використовують з мінімальними фізичними навантаженнями. Для усунення симптомів хронічного бронхіту дотримуються усіх заходів гігієни та догляду, призначають відхаркувальні, інгаляції, бронхолітики, феементні та йодисті препарати [1].

Профрілактика полягає у дотриманні суворих правил по контролю над пилом та тренінгом спортивних коней, регулюють надмірне навантаження та своєчасно лікують хворих на бронхіт тварин.

\section{Список використаних джерел:}

1. Левченко, В.І., Кондрахін, І.П. \& Судаков, М.О. (за ред. В.І. Левченка) Внутрішні хвороби тварин. (1999). Біла Церква, (1).

2. Левченко, В.І., Кондрахін, І.П.\& Л.М.Богатко та ін. (2000). Загальна терапія і загальна профілактика внутрішніх хвороб тварин. Біла Церква.

\section{ЗАЛИШКОВА КІЛЬКІСТЬ ПЕСТИЦИДІВ В МЕДІ І ПРОДУКТАХ БДЖІЛЬНИЦТВА}

Камінська Катерина Вячеславівна

студентка 3 курсу, фракультет ветеринарної медицини Національний університет біоресурсів і природокористування України

Ткачук Світлана Алімівна

доктор ветеринарних наук, професор Національний університет біоресурсів і природокористування України УКРАЇ̈А

У сучасних умовах розвитку аграрної промисловості в Україні сектор бджільництва є надзвичайно важливим і продовжує займати провідне місце не тільки на внутрішньому, але й на зовнішньому ринках.

Мед та інші продукти бджільництва є чудовими продуктами харчування та лікарськими засобами. Відомо, що до складу меду, бджолиного обніжжя, перги, маточного молочка входять різноманітні речовини: вуглеводи, протеїни, жири та жироподібні речовини, органічні кислоти, ензими, вітаміни, гормони, ароматичні речовини, мінеральні сполуки. Мед та продукти бджільництва володіють протизапальною, антибактеріальною дією, підвищують захисні сили організму людини, її життєвий тонус. Але треба зазначити, що мед і продукти бджільництва володіють високими адсорбційними властивостями, що 
приводить до нагромадження небезпечних для здоров'я людини речовин, які знаходяться у ґрунті, воді та повітрі.

Матеріалами слугували наукові та нормативні джерела, щодо контролю вмісту залишкових кількостей пестицидів хлорорганічної групи в меді бджолиному.

Як свідчить аналіз літературних даних, в останні роки проблемам удосконалення нормативної бази виробництва та якості меду приділяється значної уваги. Особливого занепокоєння викликають пестициди, порушення сільськогосподарських і гігієнічних регламентів, застосування яких веде до їх накопичення у довкіллі. Пестициди різних хімічних груп мають неоднакову стійкість, що зумовлює різну залишкову кількість їх в об'єктах навколишнього середовища. Найбільш стійкими є хлорорганічні пестициди, які заборонені для використання, але їх залишки визначають у численній кількості харчових продуктів, що пояснюється їх тривалим терміном напіврозпаду та здатністю до кумуляції. Більшість хлорорганічних пестицидів погано розчиняються у воді, але усі вони добре розчиняються в органічних розчинниках і жирах. Відмітна особливість хлорорганічних пестицидів полягає в тому, що вони довго зберігаються в організмі, накопичуються у жировій клітковині та внутрішніх органах. Ця група пестицидів стійка до дії факторів навколишнього середовища. Найважливішою хлорорганічних сполук $є$ їх здатність у великих кількостях накопичуватися в продуктах тваринного та рослинного походження. Ця група пестицидів має нейротоксичну, гепатотоксичну, канцерогенну дію на організм людини, та ембріотоксичні властивості.

Більшість з цих сполук заборонені. Нині існує перелік СО3 (стійкі органічні забруднювачі), до якого входять такі пестициди: альдрин, хлордан, дільдрин, ендрін, гептахлор, гексахлорбензол, мірекс, токсафен, дДТ (заборонений для використання у сільському господарстві, але використовується в деяких країнах для боротьби з переносниками захворювань згідно з вимогами ВОЗ), а також хлордекон, ендосульфан та ліндан (включаючи супутні альфа- і бетаізомери ГХЦГ). Максимально допустимі рівні залишкових кількостей цих речовин у продуктах харчування зарегламентовані у державних і світових стандартах.

Базові законодавчі вимоги щодо якості та безпечності бджолиного меду, що чинні в ЄC, визначені CODEX STAN 12- 1981 Standard for Honey та Council Directive 2001/110/EC, а в Україні - ДСТУ 4497:2005 «Мед натуральний. Технічні умови». Директива Ради 2001/110/ЄС відносно меду встановлює основні положення щодо вимог, яким повинен відповідати мед для вільного пересування в межах внутрішнього ринку ЄС. У ній, з урахуванням внесених змін до неї, установлюються визначення щодо різних видів меду. Затверджені загальні правила щодо його складу, а також визначена основна інформація щодо маркування, щоб гарантувати вільний рух меду у межах країн $Є С$, та щоб споживач не був введений в оману щодо якості харчового продукту. У цій директиві також визначено інтереси споживача, які стосуються географічних характеристик меду.

Забруднення навколишнього середовища та, внаслідок цього, продуктів харчування $є$ актуальною та до кінця не вирішеною проблемою сьогодення. Дуже важливим $€$ постійний державний контроль, зокрема моніторинг меду 
10 - Problems and prospects of implementation of innovative research results $\bullet$ Volume 3

бджолиного за вмістом небезпечних токсикантів, зокрема хлорорганічних сполук.

\section{Список використаних джерел:}

1. Арнаута, О. В., Томчук, О.В. \& Бернатович, О.В. (2013). Особливості нормативного забезпечення якості та безпечності бджолиного меду в Україна і ЄС на етапах його виробництва та реалізаці. Науковий вісник ЛНАУ: ветеринарні науки,(53), 5-7.

2. Каганець, О. (2010). Оцінка меду за міжнародними та національними критеріями. Продовольча індустрія АПК. № 1, $26-29$.

3. Товарознавчий вісник. (2019) Випуск 12, (47).

4. Council Directive 2001/110/EC of 20 December 2001 relating to honey, OJ L 10, 12.1.2002, p. 47-52.

5. Codex Alimentarius Commission. Revised Codex Standard for honey, Codex STAN 12-1981. Вилучено 3 http://www.codexalimentarius.org/.

6. Мед натуральний. Технічні умови: ДСТУ 4497:2005. (2007). [Чинний від 2005-12- 28]. К.: Держспоживстандарт України. 


\section{SECTION VIII. PSYCHOLOGY AND SOCIOLOGY}

\section{ESTABLISHING AN UNDERSTANDING SERVICE IN EDUCATIONAL INSTUTIONS AS A GUARANTEE FOR A PEACEFUL RESOLUTION OF CONFLICTS}

\section{Liliya Shtangret \\ Supervisor: Doctor of Philosophy, Associate Professor Olena Kolomiyets Bohdan Khmelnytsky National University at Cherkasy}

UKRAINE

Problem statement. At the present stage of peacemaking and the new ways of resolving conflicts, school bullying, one of the most pressing problems of the school environment in Ukraine, remains unchanged. The growth of school bullying is complicated by social and psychological instability in society and flaws in the organization of the educational process in institutions of general secondary education. Every year, the number of school bullying victims in Ukraine is increasing.

According to the World Health Organization, in 2016, Ukraine ranked the $9^{\text {th }}$ place among 42 countries surveyed for the percentage of victims of bullying among 15 -year-olds ( $9 \%$ girls and $11 \%$ boys) [8, p. 362]. This, in turn, led to the adoption of the new Law on Bullying by the Verkhovna Rada of Ukraine (December 18, 2018), which amends the Code of Administrative Offenses, establishes administrative liability and a certain amount of penalties for manifestations of bullying in general secondary education institutions [5].

Analysis of recent scientific research and publications. L. Lushpay, I. Berdysheva, O. Barlit, T. Alekseenko, A. Gubko, I. Sidoruk, A. Korol, D. Lane, I. Kon, devoted their research to the issues of prevention and rehabilitation of school bullying victims. However, the introduction of understanding services in general secondary education institutions as a guarantee for peaceful conflict resolution remains poorly analyzed.

The purpose of the article is to outline the basic principles of creating an understanding service in general secondary education institutions.

Presenting the main study material. It is obvious that school bullying has a number of reasons. In our opinion, researchers O. Kormylo [4] and A. Zhebrova [2] presented a reasonable understanding of the causes of this phenomenon (Fig. 1.).

In order to analyze the main measures of anti-bullying activities in Ukraine, the main vectors of anti-bullying activities were identified.

Nowadays, school bullying is a social problem that requires systematic work and a purposeful algorithm of actions to eliminate any consequences and origins of this phenomenon.

A striking example of the intensification of anti-bullying activities in Ukraine is a project - "I have the right to be myself", which was implemented by the National Police of Ukraine together with the Ukrainian Institute of Research of Extremism [1]. 
Also worthy of attention is the information campaign "\#StopBullying", from which you can find out what types of bullying and how to act if you witnessed a bullying [3].

We, in turn, believe that such work will only show effective results when working directly with bullying victims.

Simultaneously with the construction of the New Ukrainian School and the introduction of inclusive education, UNICEF, together with the Ukrainian Government, is implementing the 2018-2020 Program of Action to promote the rights of all children in Ukraine.

There is implementing of different trainings for teachers to create a comfortable educational environment. Through textbooks and lectures, children are taught tolerance and ways to identify signs of abusive behavior. This program will be assisted by Nick Vujcic, who will help to create materials for teachers in preventing school bullying [5].

Although Ukraine is just starting an anti-bullying activity, we can already talk about certain results and achievements of it. There are many ways to prevent school bullying technology and it can be done by social educators and psychologists, as well as professionals from the Centers for Social Services for the Family, Children and Youth and other social care institutions.

The work with the act of bullying involves interacting individually with the victim, the observer, and the aggressor. Or it can be the work with three main participants in this process (victim, observer and buller).

In fact, billing is the reason of the absence of some healthy dialogue between its participants, and some people may not even suspect of their own commitment of bullying.

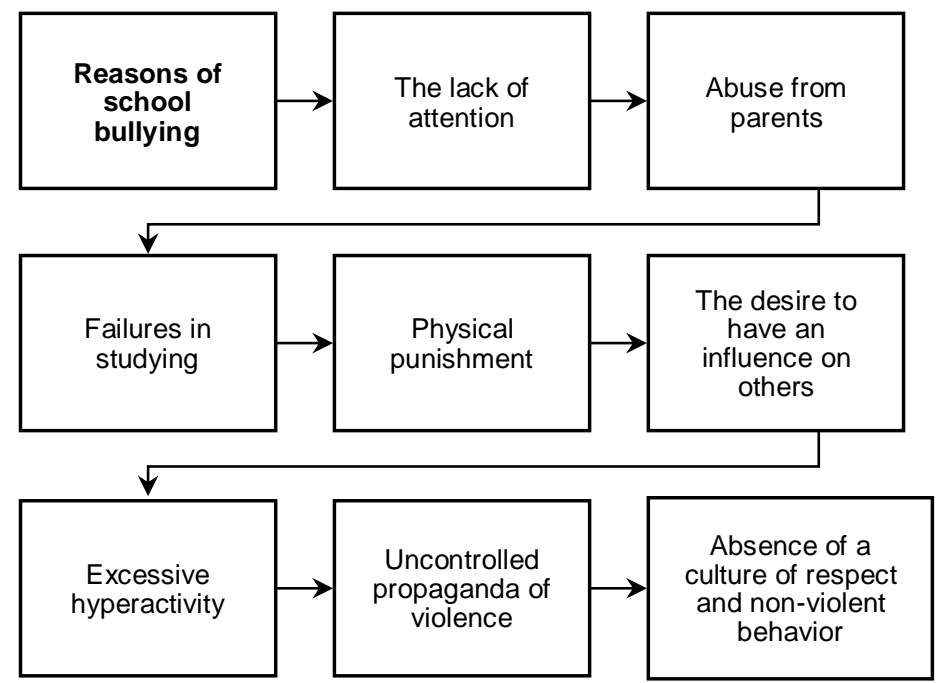

Fig. 1. Reasons of school bullying 
At this stage of changes in our society, the main priority of working with bullying in schools is neither to prevent this phenomenon nor to rehabilitate its participants.

The main goal is peacemaking. It starts with the consciousness of a particular person and then becomes a social tendency, when these ideas become a social movement, public opinion, then we can count on the desired result [6].

In our opinion, the mediation of peers will help to overcome the manifestations and the masses of bullying in educational institutions through the introduction of an understanding service, as it is a tool that combines values, principles, practices and methods of conflict resolution.

Establishing understanding services is the next step in introducing a peacemaking process in educational institutions and incorporating a philosophy of mediation into school culture.

The Understanding Service should fulfill two socially significant strategic objectives:

1) reduction of social tension in interpersonal relationships in the collective by means of mediation;

2) developing conflict-free communication skills and conflict resolution skills among all participants in the educational process.

The purpose of setting up understanding services in educational institutions is to teach and shape nonviolent behavior, the ability to avoid conflicts, and in case of its occurrence, not to cause the turning conflict into violence [7].

The ability to find the right way out of difficult situations and build ecological relationships with the coordinates of "I +, You $+"$ is the basis for creating the foundations of a conflict-free environment.

Creating and operating an understanding service for a long time is impossible without the use of project-based technologies. That is why it requires purposeful and coordinated actions of different nature - organizational, methodological, research, analytical, informational, etc. But there is the necessity for continuous monitoring of the functioning of the service and periodic evaluation of both individual members and the service as a whole. [7].

The organization of the understanding service in educational establishments should follow the following principles.

The priority of mediation values. Everyone should understand that some things are mandatory, static and inviolable. In particular, voluntary participation, equal rights of the parties, neutrality of the mediator and confidentiality of the process.

Independence. The understanding service has a special status because it consists of volunteers. Anonymity is rather relative and extends on the choice of forms and methods of work, on the ways of information dissemination, the organization of the mediation process, the setting of goals.

Accessibility. Anyone involved in the educational process can contact the Understanding Service.

Development. Understanding services must have a permanent professional support to ensure continuous training and the service itself should be always flexible and ready for change.

The understanding service should first and foremost benefit the participants in the educational process, such as preventing bullying, formation of a culture of peace, establishing positive peer relationships.

The understanding service performs the following functions:

Preventive - prevention of escalation and negative consequences of conflict situations; 
Pedagogical - self-realization, development of communication skills and personal qualities;

Reinstatement - restoration of broken relationships, status of participants in the conflict;

Educational - acquisition and improvement of conflict resolution skills, formation of outlook, development of social competences;

Upbringing - education of responsible attitude to one's own actions and words, tolerant attitude to emotions and feelings [7].

Each of the above functions should be implemented in one form or another. The integrated nature of their implementation is a key component in creating a peaceful foundation for coexistence and cooperation in general secondary education institutions.

It is important to realize that the service of understanding in the educational institution is guided by normative legal acts and the Code of Ethics of the mediator.

Since the creation of a mutual understanding service is the basis of peacemaking among students of educational institutions, the key to a proper demand for restorative services is a loyal devotion to the principles of mediation, which ensures a high level of confidence.

Conclusion and further perspectives. It can be concluded that the success of a conflict-free environment in an educational institution lies in the systematic introduction of restorative practices into the educational process aimed at preventing conflicts. All participants in the educational process, including service staff, must have the knowledge and skills to resolve conflicts peacefully.

Therefore, educational institutions need to learn through the services of understanding how to build a non-violent model of behavior and the ability to resolve conflicts constructively, peacefully. Only under such conditions it will help to activate the development of the personality of the modern student, reduce personal and destructive conflicts, will form in children a modern vision of their own development and build peace around them.

\section{References:}

1. Study: "Stop School Terror. Prevention and Countering of Bullying". Ukrainian Institute of Research of Extremism. (2019) Retrieved from: https://www.depo.ua/ukr/life/v-ukrayinistartuvala-informaciyna-kampaniya-stopbuling-20180806817483 (in Ukr.).

2. Zhebrova A. O. Bullying as a type of torture among teenagers. STOP BULLYING. (2018) Retrieved from: https://docviewer.yandex.ua/view/ (in Ukr.).

3. \#StopBullying information campaign. UNICEF Ukraine. (2018) Retrieved from: https://www.stopbullying.com.ua/materials (in Ukr.).

4. Kormylo O. (2015) The phenomenon of bullying in the educational sphere. Problems of the humanities. Psychology Series. 35. 174-187 (in Ukr.).

5. Amendments to Some Legislative Acts of Ukraine on Countering Bullying: Law of Ukraine of (2018) Retrieved from: http://search.ligazakon.ual/_doc2.nsf/link1/JH6MG00A.html (in Ukr.).

6. Peace making. Prevention and resolution of conflict using mediation: a socio-pedagogical aspect. (2016) In V.V. Stetsenko. (Ed.). Kyiv (in Ukr.).

7. Establishment of peer-to-peer mediation services and peaceful settlement of educational institutions. (2018) Kyiv (in Ukr.).

8. Annual report on the state of health of the population, the sanitary-epidemic situation and the results of the activity of the health care system of Ukraine by the results of 2016. (2017) Kyiv (in Ukr.). 


\section{PROBLEMS OF GENDER INEQUALITY IN THE LABOR MARKET IN UKRAINE}

Anastasiia Fadieieva

student of 2nd medical faculty Kharkiv National Medical University

Alina Valentieva

student of 2nd medical faculty Kharkiv National Medical University

SCIENTIFIC ADVISER:

Nataliya Martynenko

PhD in History, Associate Professor Kharkiv National Medical University

UKRAINE

The relevance of the problem of gender inequality in the labor market is that, despite the declared norms, the position of women and men in employment cannot be considered equal. Ukraine is ranked 64th out of 135 in the Equality Rating article published by the World Economic Forum. This indicates that the rules indicated in the regulatory documents are not fully complied with.

According to statistics, men and women have equal access to education. At the same time, in schools of girls and boys about the same number (since secondary education is compulsory for all citizens of Ukraine now), and in higher educational establishments the number of women is $21 \%$ higher than men. But already at employment the situation changes. Although the unemployment rate for women is slightly lower than for men, it can be said that women work more in low-wage jobs. Not only discrimination in the distribution of posts, but also the wage gap between women and men who hold the same positions and have almost identical achievements is also very pronounced. In such situations, the wages of men are much higher.

All of these factors affect women's career aspirations: they lose ambition and accept the privileges of men. It is interesting that women are more often opposed to women in leadership positions than women themselves. It is clear that such a position in society does not allow the full development of personality and equal rights of all people, regardless of their gender.

Usually, opportunities for implementation are assessed in the following areas of life: politics, employment, education and health. And you can see that inequality in all these areas is quite different.

Speaking of politics, it is not uncommon to meet women in this field: women make up only $19 \%$ of the Verkhovna Rada deputies. If you mention the local selfgovernment bodies, the number of women there can reach $20 \%$ (as in Kharkiv and Kherson regions), and can be as high as 10\% (as in Odesa and Vinnitsia regions). Therefore, it can be argued that policy inequalities are very common. This strongly affects the problem of discrimination in other areas of society, since politics is an area that should guide and lead by example in other areas of people's lives. 
On the issue of employment, it is known that the choice between two candidates with the same education will be given priority to a man. It is important that when hiring for leadership positions, they are likely choose man, and to a place that requires constant contact with people, will offer woman. This is due to the stereotype that woman can never be a true leader but can find common ground with men.

If we consider the field of education, we can say that in Ukrainian higher educational establishments, women make up $80 \%$ of teachers, and only $20 \%$ of the heads of these institutions. There are also difficulties in obtaining scientific titles, since among academics of the NAS of Ukraine women make up only $1 \%$.

Unlike all previous sectors, discrimination in health care is the least pronounced: the gender pay gap does not exceed $10 \%$ (compared to $35 \%$ in the financial sector), the positions of men and women are approximately equal frequency. Although the number of women in health care is much higher than that of men, this is explained by the ratio of men to women among graduates of medical schools.

Thus, the problem of gender discrimination in the labor market in Ukraine remains quite acute. To eliminate this problem, it is necessary to create a culture of gender equality in the society, to improve the mechanism of control over the implementation of gender equality principles at the state level, to create conditions for ensuring equal opportunities in employment.

\title{
КРЕАТИВНСІТЬ, ЛОКУС КОНТРОЛЮ ТА ОСОБЛИВОСТІ ЇХ ЗВ'ЯЗКУ ІЗ СИМПТОМАМИ ДЕПРЕСІЇ В ОСІБ ЮНАЦЬКОГО ВІКУ
}

\begin{abstract}
Ортинська Крістіна Вячеславівна
студентка фракультету політико-інфрормаційного менеджменту Національний університет "Острозька академія»
\end{abstract}

Науковий керівник: Нікітчук Уляна Ігорівна канд. психол. наук., доцент кафедри громадського здоров'я Національний університет «Острозька академія»

УКРÄ̈HA

За МКХ-11 депресивні розлади класифікуються: 6А70 депресивний розлад в одиночному епізоді; 6А71 рецидивуючий депресивний розлад; 6А72 дистимічний розлад; 6А73 змішаний депресивний і тривожний розлад; GA34.41 передменструальний дисфоричний розлад; 6А7Y інші вказані депресивні розлади; $6 \mathrm{~A} 7 \mathrm{Z}$ депресивні розлади, не визначені [12].

За DSM-5 великий депресивний розлад класифікується як розлад настрою. Діагноз залежить від наявності окремих або періодичних великих депресивних епізодів. Інші класифрікатори використовуються для класифікації як самого епізоду, так і перебігу розладу. Згідно DSM-5, є два основні депресивні симптоми - пригнічений настрій та втрата інтересу / задоволення від діяльності (ангедонія). Ці симптоми, а також п'ять із дев'яти перерахованих більше специфічних симптомів мають часто виникати протягом двох тижнів для 
встановлення діагнозу. Загальною особливістю всіх цих розладів $є$ наявність почуття суму, пустоти, дратівливого настрою, що супроводжується соматичними та когнітивними змінами, які суттєво впливають ефективність фрункціонування [3].

Велика депресія є одним із найпоширеніших психічних розладів, четвертою провідною причиною недієздатності у всьому світі та ймовірно, що до 2020 року буде другою провідною причиною. Відповідно до статистичних показників, великий депресивний розлад наявний приблизно 216 мільйонів людей $(3 \%$ населення світу) у 2015 році. У 2017 році 264 мільйони людей у світі пережили депресію [10].

Встановлено, що особи, які схильні до виникнення депресії, зазвичай мають надмірно песимістичні та самокритичні способи інтерпретації подій та обставин, із почуттям безпорадності та безнадії щодо зміни чи покращення своєї ситуації [5]. Диссрункційність мислення призводять до загострення та збереження симптомів дисфорії та беззмістовності, іноді до виникнення епізодів великої депресії та суїцидальності [9].

Стратегії регулювання емоцій, румінація, можуть стати дезадаптивними та значно погіршити психосоціальне функціонування. Між емоційною регуляцією та депресією існує сильний зв'язок [11]. Встановлено, що при застосуванні адаптивних когнітивних стратегій емоційної регуляції (наприклад, переоцінки) знижується ймовірність виникнення стресових емоцій, що призводять до психічних або фрізичних розладів [13]. І навпаки, емоційна дисрегуляція (наприклад, румінація, витіснення та придушення емоцій, тощо), впливає на патогенез психологічних захворювань, таких як депресія. Доведено, що румінація характеризує депресію, та прогнозує більш сильні депресивні симптоми, початок депресивних епізодів [15]. Більша тенденція до румінації, крізь призму негативних когнітивних упереджень або стилів мислення, передбачає більшу тривалість депресивних епізодів [8].

Дж. Кауфрман та Р. Бегето сформували модель креативності «чотири - с». Відповідно до цієї моделі креативність поділяється на чотири типи: креативність «Mini-с» передбачає особисто сформовані важливі ідеї та інсайти, які відомі лише особі; креативність «Little-c» включає в себе повсякденне мислення і вирішення проблем. Цей тип креативності допомагає людям вирішувати щоденні справи, з якими вони зіштовхуються, i адаптуватися до мінливих умов; креативність «Pro-С» характерна особам, які $€$ профресіоналами у певній справі, $є$ кваліфікованими та творчими у своїх галузях. Ці особистості є творчими у своєму покликанні або професії, але не стають визначними у своїй роботі; креативність «Вig-С» передбачає продукування витворів та ідей, які вважаються великими у певній галузі. Цей тип креативності характерний для осіб, які мають високий рівень визнання своєї діяльності. Креативність типу «Big-С» спричиняє зміни у відповідних галузях, наприклад: медичні інновації, технологічні досягнення та художні досягнення [14].

Опираючись на модель креативності 4-с, ми у нашому дослідженні розглядатимемо поняття креативність як здатність продукувати значну кількість ідей та варіантів вирішення життєвих проблем, здатність долати життєві труднощі, відповідно до моделі це креативність «Mini-c» та «Little-c», 
оскільки це визначення найбільш відповідає контексту нашого дослідження [14].

На думку Дж. Гілфорда, дивергентне мислення $є$ основою креативності. Окрім цього виду мислення до структури креативності були віднесені здатність до перетворень, точність рішення та інші інтелектуальні параметри [1]. Цим відзначався позитивний зв'язок між інтелектом і креативністю. Оскільки в нашому дослідженні ми розглядаємо поняття креативності у контексті вирішення життєвих проблем, а рівень інтелекту є одним з факторів впливу на особливості формування варіантів вирішення проблем, нас цікавить чи вливає рівень інтелекту на особливості прояву депресії. Поняття локус контролю визначається як ступінь, за якою люди вважають, що контролюють результати своїх дій у житті.

У дослідженні взаємозв'язку між локусом контролю та депресією взяло участь 34 особи юнацького віку. Вибірку дослідження наявності зв'язку між креативністю та депресією становили 20 осіб юнацького віку (які одночасно входять до вибірки для дослідження взаємозв'язку між локусом контролю та депресією).

Наше дослідження мало три частини. На першому етапі (емпірична частина) дослідження ми мали з'ясувати чи наявний кореляційний зв'язок між рівнем креативності, інтелектом та депресією, та чи є статистично значимі відмінності у показниках рівня прояву депресії відносно орієнтації локусу контролю.

Отож, на першому етапі ми виміряли в респондентів рівень креативності, визначили спрямованість локусу контролю, дослідили наявність депресивної симптоматики, та визначили рівень інтелекту. Для реалізації нашого плану, ми застосували наступні інструменти: опитувальник депресії Бека, тест Дж.Роттера Локус контролю, тест креативного мислення Торренса (вербальна та образна частини) [1]. Для дослідження інтелекту ми використали тест структури інтелекту Амтхауера, цей тест має 9 субтестів, які дають можливість різносторонньо дослідити прояв інтелекту. Для проведення опитування ми використали додаток Google Форми, крім образної частини тесту Торренса.

Щоб емпірично встановити наявність зв'язку між креативністю, локусом контролю, інтелектом та симптомами депресії, ми застосували наступні методи математично-статистичної обробки емпіричних даних: коефіцієнт кореляції Спірмена, однофракторний дисперсійний аналіз ANOVA, $X^{2}$ Пірсона, t-критерій Стьюдента. Для того, з'ясувати чи є зв'язок між креативністю, рівнем інтелекту, та депресією ми використаємо коефіцієнт кореляції Спірмена. Після встановлення кореляційного зв'язку між згаданими вище феноменами, для того, щоб встановити статистично значимі відмінності у показниках рівня прояву депресії залежно від рівнів креативності та інтелекту ми застосували однофракторний дисперсійний аналіз ANOVA. Щоб встановити наявність чи відсутність статистично значимих змін прояву симптомів депресії відносно локусу контролю ми використали критерій $\mathrm{X}^{2}$.

Після встановлення наявності зв'язку між креативністю, локусом контролю та депресією ми перейшли до експериментальної частини нашого дослідження. На цьому етапі ми за допомогою розробленої тренінгової програми, яка спрямована на підвищення рівня креативності, здійснили 
експериментальний вплив. Після проведення тренінгу, ми розпочали останню фазу дослідження.

Наше завдання полягало в тому, щоб повторно зібрати показники рівня креативності, локусу контролю, інтелекту та депресії. Для цього ми використали ті ж самі опитувальники, які використовували під час проведення першої частини нашого дослідження. Далі ми знову за допомогою методу математично-статистичної обробки емпіричних даних ми перевірили наявність кореляційного зв'язку між креативністю, інтелектом та симптомами депресії, для цього ми використали ті ж критерії математично-статистичної обробки даних, що і в першій частині дослідження.

На завершення, ми порівняли всі результати вимірювань «до» та «після». Показники рівня прояву депресії, креативності та інтелекту ми опрацювали, використавши t-критерій Стьюдента для парних вибірок. Таким чином ми дізналися чи наявні статистично значимі зміни після здійснення експериментального впливу. Показники локусу контролю ми опрацювали за допомогою критерію $\chi^{2}$ Пірсона.

За результатами емпіричної частини дослідження нам вдалося встановити, що у $43 \%$ респондентів спостерігається мінімальний рівень прояву депресивної симптоматики, 33\% має м'який рівень прояву симптомів, та $24 \%$ респондентів мають помірний рівень прояву депресивної симптоматики. Серед усіх вимірюваних проявів депресії найбільше виражені: пригніченість настрою 54\% респондентів, песимістичні настрої та переконання стосовно майбутнього $50 \%$, наявність відчуття провини $65 \%$, підчищена самокритичність 59\%, відчуття неспокою та тривоги 53\%, підвищена втомлюваність 56\%, зміни апетиту 59\%, погіршення сну та недосипання $74 \%$, зниження рівня енергії 71\%/

Найрідше проявляються: зменшення задоволення 59\%, негативне ставлення до минулого досвіду $76 \%$, у $79 \%$ опитуваних відсутнє відчуття покарання, втрати інтересу до оточуючих не мають $56 \%$ респондентів, у $62 \%$ опитуваних відсутні проблем із прийняттям рішень, $70 \%$ опитуваних має позитивне ставлення до себе, не виражається плаксивість $79 \%$ респондентів, зменшення сексуального потягу не спостерігається у $80 \%$ опитуваних чоловіків та у $76 \%$ жінок, у $71 \%$ відсутні думки про самогубство, відчуття меншовартості не спостерігається у 59\%, зміни в особливостях протікання когнітивних процесів не виявлені у $62 \%$ респондентів.

Кореляційний аналіз продемонстрував, що між вербальною креативністю $r=-0.55$ при $p \leq 0,05$, біжучістю $r=-0.54$ при $p \leq 0,05$, гнучкістю $r=-0.51$ при $p \leq 0,05$, біжучістю образної креативності $r=-0.43$ при $p \leq 0,05$, пропрацьованістю варіантів $r=-0.46$ при $p \leq 0,05$ наявний статистично значимий, обернений кореляційний зв'язок середньої сили із депресією. Також, нам вдалося встановити наявність оберненого статистично значимого кореляційного зв'язку середньої сили між інтелектом та депресією $r=-0.48$ при $p \leq 0,05$. Ми встановили наявність статистично значимих відмінностей прояву симптомів депресії відносно локусу контролю $\mathbf{X}^{2}=8.70$ при $p=0.01$.

Статистично не значимий результат ANOVA, $\mathrm{F}>0,05$ показав, що відмінностей у показниках депресії у розрізі різних рівнів: вербальної креативності, біжучості, гнучкості, біжучості образної креативності, 
пропрацьованості варіантів відповідей та рівнем інтелекту у досліджуваних не виявлено. Невелика вибірка могла зумовлювати похибку у вимірюваннях ANOVA. Але ми можемо припустити, про наявність тенденції зниження рівня прояву депресії залежно від зростання: рівня вербальної креативності, показників біжучості вербальної креативності, гнучкості вербальної креативності, біжучості образної креативності, пропрацьованості та рівня інтелекту.

Як експериментальний засіб впливу ми використали розроблену нами тренінгову програму. Здійснивши повторний кореляційний аналіз показників, ми встановили, що між вербальною креативністю $r=-0.46$ при $p \leq 0,05$, біжучістю $r=-0.44$ при $p \leq 0,05$, гнучкістю $r=-0.49$ при $p \leq 0,05$, біжучістю образної креативності $r=-0.44$ при $p \leq 0,05$, інтелектом $r=-0.48$ при $p \leq 0,05$ та депресією наявний статистично значимий, обернений кореляційний зв'язок середньої сили.

Статистично не значимий результат ANOVA, F > 0,05 показав, що відмінностей у показниках депресії у розрізі різних рівнів вербальної креативності, біжучості, гнучкості, біжучості образної креативності, інтелекту у досліджуваних не виявлено. На результати за однофакторним дисперсійним аналізом ANOVA могла вплинути невелика вибірка, спричинивши похибку у вимірюваннях. Але отримані результати не спростовують наявність тенденції до зниження рівня прояву депресії залежно від зростання рівня вербальної креативності, показників біжучості, гнучкості, біжучості образної креативності та рівня інтелекту.

Отримані результати дають нам можливість стверджувати, що відмінності у показниках депресії до ( $M=12.20 ; S D=7.410)$ та після $(\mathrm{M}=10.35 ; \mathrm{SD}=7.436)$ тренінгу є статистично значимими [t $(40)=5.403 ; p=0.01]$. Також, нам вдалося встановити наявність статистично значимих [t $(40)=-3.886 ; \mathrm{p}=0.01]$ відмінностей у показниках вербальної креативності до $(\mathrm{M}=28.51$; $\mathrm{SD}=6.284)$ та після ( $M=29.50 ; S D=6.477)$ тренінгу. Було встановлено, що відмінності у показниках біжучості до ( $\mathrm{M}=26.85 ; \mathrm{SD}=4.714)$ та після $(\mathrm{M}=28.61 ; \mathrm{SD}=5.420)$ тренінгу $є$ статистично значимими [t $(40)=-6.845 ; p=0.01]$. За показником гнучкість нам теж вдалося встановити наявність статистично значимих відмінностей $[\mathrm{t}(40)=-4.746 ; \mathrm{p}=0.01]$ між показниками до $(\mathrm{M}=24.19 ; \mathrm{SD}=7.415)$ та після ( $\mathrm{M}=25.40 ; \mathrm{SD}=7.863)$ тренінгу. Також не було виявлено статистично значимих відмінностей [t $(40)=-1.674 ; p=0.110]$ у рівнях прояву інтелекту до $(\mathrm{M}=95.85 ; \mathrm{SD}=8.235)$ та після ( $\mathrm{M}=95.85 ; \mathrm{SD}=8.235)$ проведення тренінгу.

Порівнявши показники за результатами тесту образної креативності ми встановили наявність статистично значимих відмінностей [t $(40)=-51.580 ; p=$ 0.00] між рівнем прояву образної креативності до ( $\mathrm{M}=2.35 ; \mathrm{SD}=0.813)$ та після ( $\mathrm{M}=37.89$; $\mathrm{SD}=3.623$.) проведення тренінгу. За показниками рівнів прояву біжучості образної креативності до ( $\mathrm{M}=39.55$; $\mathrm{SD}=3.845)$ та після ( $\mathrm{M}=41.25$; $\mathrm{SD}=4.339$.) проведення тренінгу $є$ статистично значимі відмінності $[\mathrm{t}(40)=-$ 4.501; $\mathrm{p}=0.01$ ]. Статистично значимі відмінності [t $(40)=-4.501 ; \mathrm{p}=0.01]$ між рівнями прояву наявні у показниках оригінальності до ( $M=32.60 ; S D=4.453)$ та після $(\mathrm{M}=36.95 ; \quad \mathrm{SD}=4.211$.$) \quad здійснення впливу. За показником$ пропрацьованість відповідей теж наявні статистично значимі відмінностей $[\mathrm{t}$ $(40)=-4.417 ; p=0.01]$ у рівнях прояву до ( $M=33.55 ; \mathrm{SD}=4.174)$ та після (M 
=36.90; $\mathrm{SD}=3.892$.) проведення тренінгу. Відмінності у показниках абстрактність назви до ( $\mathrm{M}=32.05 ; \mathrm{SD}=4.097)$ та після $(\mathrm{M}=37.25 ; \mathrm{SD}=3.416)$ тренінгу $є$ статистично значимими [t $(40)=-5.638 ; p=0.01]$. Нам вдалося встановити наявність статистично значимих відмінностей [t $(40)=-6.388 ; \mathrm{p}=$ 0.01] у рівнях прояву показника «супротив до замикання» до ( $\mathrm{M}=31.35$; $\mathrm{SD}$ $=4.056)$ та після (M =36.70; $S D=3.536)$ тренінгу.

Статистично значимих відмінностей у рівнях прояву локусу контролю до та після проведення тренінгу не було встановлено. Також не було виявлено статистично значимих відмінностей [t $(40)=-1.674 ; p=0.110$ ] у рівнях прояву інтелекту до ( $\mathrm{M}=95.85 ; \mathrm{SD}=8.235)$ та після $(\mathrm{M}=95.85 ; \mathrm{SD}=8.235)$ проведення тренінгу.

Результати дослідження Афріфі продемонстрували зв'язок між локусом контролю та підлітковою депресією [2]. Браун і Зігель виявили зв'язок між локусом контролю і депресивним розладом. Вони виявили, що респонденти, які мали зовнішній локус контролю мали підвищення депресивних проявів. I навпаки, внутрішній локус контролю був пов'язаний з менш депресивними проявами [5]. Також, Чорпіта визначив, що особи із зовнішнім локусом контролю мають підвищений ризик розвитку депресії [7]. Бенкс та Гоггін з'ясували, що зовнішній та внутрішній локуси контролю були пов'язані 3 депресією. Бьоргег виявив, що показник локусу контролю, пов'язаний з рівнем депресії, також, встановив що особи із зовнішнім локусом контролю більш схильні до самогубства $[4,6]$.

Висновки. Опираючись на результати емпіричного та експериментального дослідження, ми можемо стверджувати, що наявна тенденція до зменшення рівня прояву депресивної симптоматики, залежно від зростання рівнів прояву креативності, інтелекту у осіб юнацького віку. Також ми встановили, що наявні статистично значимі відмінності рівнів прояву депресії залежно від локусу контролю. Отримані результати можуть бути основою для профрілактичних заходів депресії, оскільки низький рівень креативності та зовнішній локус контролю можуть сприяти появі афективних розладів, також отримані результати можуть допомогти у формування нових засобів, методів та інструментів інтервенції для депресії. У подальшій перспективі ми б хотіли провести дослідження на більшій вибірці.

\section{Список використаних джерел:}

1. Туник Е. Е. Диагностика креативности. Тест Е

2. Afifi, M., Al Riyami, A., Morsi, M., \& Al Kharusil, H. (2006). Depressive symptoms among high school adolescents in Oman. Eastern Mediterranean Health Journal, 12 (Supplement n.2), S126-S137

3. American Psychiatric Association, Diagnostic and Statistical Manual of Mental Disorders, American Psychiatric Publishing, Arlington,Va, USA, 5thedition, 2013.Clinically Significant Depression Overview web.URL https://www.verywellmind.com/clinically-significantdepression1067143

4. Banks, L. M., \& Goggin, W. C. (1983). The relationship of locus of control and attribution to depression. (Report No. CG-017). Paper presented at the annual Meeting of the Southeastern Psychological Association (29th, Atlanta, GA, March 23-26, 1983). (ERIC Document No. ED236461) 
5. Brown, J. D., \& Siegel, J. M. (1988). Attribution for negative life events and depression: The role of perceived control. Journal of Personality and Social Psychology, 54, 316-322.

6. Burger, J. M. (1984). Desire for control, locus of control, and proneness to depression. Journal of Personality, 52 (1), 71-89.

7. Chorpita B.F. Control and development of negative emotion. In: Vasey M.W., Dadds M.R., editors. The Developmental Psychopathology of Anxiety. Oxford University Press; New York: 2001

8. Compas, B.E., Jaser, S.S., and Benson, M. (2008). Coping and emotion regulation: Implications for understanding depression during adolescence. In S. Nolen-Hoeksema, editor; and L. Hilt, editor. (Eds.), Handbook of Depression in Adolescents (pp. 419-439). New York: Routledge.

9. Cropley, A. J. (2011). Definitions of creativity. In M. A. Runco \& S. R. Pritzker (Eds.), Encyclopedia of creativity (pp. 511-524). San Diego, CA: Academic Press.

10. Depression and Other Common Mental Disorders: Global Health Estimates. Geneva: World Health Organization; 2017. Licence: CC BY-NC-SA 3.0 IGO

11. Demeyer I, de Lissnyder E, Koster EHW, de Raedt R. Rumination mediates the relationship between impaired cognitive control for emotional information and depressive symptoms: a prospective study in remitted depressed adults. Behaviour Research and Therapy. 2012;50(5):292-297.

12. ICD-11 for Mortality and Morbidity Statistics (Version : 04 / 2019) https://icd.who.int/browse $11 / \mathrm{m} /$ en\#/http\%3a\% 2f\% 2fid. who.int $\% 2 f i c d \% 2 f e n t i t y \% 2 f 1563440232$

13. J. Min, J. J. Yu, C. Lee, and J. Chae, "Cognitive emotion regulation strategies contributing to resilience in patients with depression and/or anxiety disorders," Comprehensive Psychiatry,vol.54,no.8,pp.1190-1197,2013.

14. James C. Kaufman Bernardino Ronald A. Beghetto Beyond Big and Little: The Four C Model of Creativity. 2009 American Psychological Association 2009, Vol. 13, No. 1, 1-12 10892680/09/12.00 DOI: 10.1037/a0013688

15. Nolen-Hoeksema, S. (2000). The role of rumination in depressive disorders and mixed anxiety/depressive symptoms. Journal of Abnormal Psychology, 109, 504-511.

\title{
DOI 10.36074/13.12.2019.v3.01
}

\section{ПСИХОЛОГИЧЕСКИЕ ОСОБЕННОСТИ РЕГУЛЯЦИИ СТРЕССА}

\begin{abstract}
Кернас Андрей Вячеславович
гандидат психологических наук, с.н.с., руководитель отдела Естественных наук и психологической гармонизации развития личности Научно-технический центр Академии связи Украины

УКРАИНА
\end{abstract}

Общеизвестен тот фракт, что стресс является неотъемлемым спутником жизни каждого человека. Как отмечает Р.М. Грановская, стресс является составной частью жизни каждого человека, и его нельзя избежать так же, как еды и питья. Он создает «вкус к жизни». Жизнь утрачивает свой вкус, если многие удовольствия могут быть получены очень легко, поскольку в этом случае стремительно падает мотивация к действию. Весьма важно и его поначалу стимулирующее влияние в сложных процессах воспитания и 
обучения. Но стрессовые воздействия не должны превышать приспособительные возможности человека, ибо в этих случаях возникает ухудшение самочувствия и даже заболевание - соматическое или невротическое. Остановимся немного подробнее на том, почему это происходит. Люди реагируют на одинаковые нагрузки по-разному. У одних реакция активная. При стрессе эффективность их деятельности достаточно долго продолжает расти (так называемый «стресс льва»), а у других реакция пассивная, эффрективность их деятельности быстро падает («стресс кролика») [1].

На основании проведенного нами анализа научной и научно-методической литературы мы можем констатировать следующее. Термин «стресс», получивший в наши дни столь широкое распространение, впервые был введен в научное употребление применительно к техническим объектам. B XVII в. английский ученый Роберт Гук применил этот термин для характеристики объектов (например, мостов), испытывающих нагрузку и сопротивляющихся ей. Эта историческая аналогия интересна тем, что понятие «стресс» в современной физиологии, психологии, медицине (базирующейся на клинических исследованиях Г. Селье) включает в себя представления о связях стресса с нагрузкой на сложные системы (биологические, психологические, социально-психологические) и с сопротивлением этой нагрузке. В соответствии с этими представлениями стресс рассматривается как физиологический синдром, слагающийся из совокупности неспецифически вызванных изменений, как неспецифическая реакция организма на предъявляемые к нему требования. Характер этого синдрома относительно независим от вызвавших его фракторов (стрессоров), что позволило Селье говорить об общем адаптационном синдроме [3].

Итак, в рамках теории Г. Селье к стрессу относятся реакции организма на любые достаточно сильные воздействия среды, если они запускают ряд общих процессов с участием коры надпочечников. В то же время сам основатель учения о неспецифическом адаптивном синдроме выделял две его формы: стресс полезный - эустресс и вредоносный - дистресс. Однако чаще под стрессом понимают реакции организма именно на негативные воздействия внешней среды, что находит свое отражение в определениях, которые дают этому френомену различные исследователи [4].

Представления об эмоциональном (психическом) стрессе сформировались благодаря тому, что в междисциплинарных исследованиях была установлена роль психических фракторов в развитии состояния стресса. Многолетние исследования психического стресса подтвердили общность фризиологических изменений, возникающих при фризиологическом и психическом стрессе, и в то же время позволили говорить о некоторых важных различиях в механизмах их формирования. Если физиологический стресс возникает в связи с непосредственным физическим воздействием, то при эмоциональном стрессе влияние психических стрессоров (или комплексной стрессогенной ситуации) опосредуется через сложные психические процессы. Эти процессы обеспечивают оценку стимула и сопоставление его с предыдущим опытом. Стимул приобретает характер стрессора, если в результате такой психологической переработки стимула возникает ощущение 
угрозы. Обычно это имеет место в том случае, если психологическая оценка обнаруживает очевидное несоответствие между требованиями среды и потребностями субъекта, его психическими и фризическими ресурсами, которые необходимы для удовлетворения этих потребностей. Субъективное отношение к стимулу, зависящее от неповторимого индивидуального опыта (в значительной мере восходящего к периоду раннего детства), личностных особенностей, характера когнитивных процессов и психического состояния, представляет собой важный психологический механизм и определяет индивидуальную значимость стрессора [1].

Выделяют три стадии развития стресс-реакции. Рассмотрим их более детально.

1. Стадия тревоги. На этой стадии происходит мобилизация организма, а также формируется готовность к психической и физической деятельности, адекватной ситуации.

2. Стадия повышенной сопротивляемости и устойчивости. Происходит адаптация к изменившейся ситуации за счет поддержания принципиально нового (более высокого и, следовательно, энергозатратного) режима работы функциональных систем организма. Чаще всего человек самостоятельно купирует стрессовую реакцию на 1-2-й стадиях, найдя выход из положения.

3. Стадия истощения (дистресс). Если раздражитель продолжает действовать, то происходит снижение общей сопротивляемости организма, так как исчерпываются его физические и психологические резервы. Стресс захватывает человека и может привести его к болезни и даже к смерти [2].

Исследование проводилось на базе Отдела естественных наук и психологической гармонизации личности Научно-технического центра Академии связи Украины.

Выборку испытуемых составили 18 человек в возрасте от 19 до 43 лет.

В ходе проведенного исследования нами использовались методы наблюдения, бесед, анкетирования, входе которого нами использовался следующий психодиагностический инструментарий: 1. Методика определения нервно-психической устойчивости, риска дезадаптации в стрессе «Прогноз»; 2. Методика измерения уровня тревожности Тейлора; 3. Методика оперативной оценки самочувствия, активности, настроения (САН) В.С.Доскина; 4. Тест самооценки вегетативных проявлений стресса Ю.В.Щербатых.

Исследование проводилось в течение двух календарных месяцев.

Формирующий эксперимент:

1 этап. Предварительное знакомство и проведение комплекса психодиагностических методик.

2 этап. Проведение лекционных занятий, направленных на передачу участникам эксперимента теоретических и практических знаний, позволяющих на основании самонаблюдения за своими психологическими реакциями на стрессоры правильно оценивать состояние своего организма и вносить целенаправленные коррективы в его работу.

3 этап. Проведение групповых занятий, направленных на изучение и последующее практическое использование методик оптимизации уровня стресса: 
Аутогенная тренировка;

Нервно-мышечное расслабление;

Метод биологической обратной связи;

Медитация.

4 этап. Повторное проведение психодиагностики.

По итогам проведенного исследования, на основании сопоставления данных психодиагностики до и после проведения формирующего эксперимента, мы можем сделать выводы о положительном влиянии на испытуемых предлагаемого нами набора методик в их комплексном взаимодействии.

\title{
Список использованных источников:
}

1. Грановская, Р.М. (2003). Элементы практической психологии. СПб.: Речь.

2. Лекарство от стресса (2013). СПб.: Амфора.

3. Психология мотивации и эмоций (2009) / под ред. Ю.Б. Гиппенрейтер, М.В.Фаликман. М.: АСТ: Астрель.

4. Щербатых, Ю.В.. (2008). Психология стресса и методы коррекции. СПб, Питер.

\section{УКРАЇНСЬКА НАРОДНА ІГРАШКА ЯК ЗАСІБ ФОРМУВАННЯ У ДОШКІЛЬНИКІВ ЦІННІСНОГО СТАВЛЕННЯ ДО НАРОДНОї КУЛЬТУРИ}

\begin{abstract}
Яценко Тетяна Володимирівна кандидат психологічних наук, завідувач кафедри психології та педагогіки Кременчуцький педагогічний коледж імені А. С. Макаренка

Корнєєва Дар'я Сергіївна здобувач освітньо-кваліфікаційного ступеню бакалавр спеціальність 012 Дошкільна освіта Кременчуцький педагогічний коледж імені А. С. Макаренка УКРÄ̈HA
\end{abstract}

Народну іграшку можна назвати унікальним явищем традиційної народної культури українців. Вона $€$ предметом народної гри, методом виховання і розвитку дитини, об'єктом творчості, реліктом автентичної культури, художнім витвором, національним сувеніром тощо. В іграшці об'єдналися тисячолітні традиції народного художнього мистецтва, яке відроджується у сучасному світі [1].

Український педагог С. Русова наголошувала, щоб виховання розпочиналося вже з народження дитини. Засобами колискової, забавлянок, народних казок, ігор, іграшок, лічилок, загадок, тощо має здійснюватися прилучення дітей до національної культури та підвищуватись національна свідомість підростаючої особистості. Вона говорила, що нація народжується 
біля дитячої колиски, лише на рідному ґрунті, серед рідного слова, пісні, здатна вирости національно свідома людина.

Останнім часом батьки та педагоги усе менше бавлять малят народними іграшками. Завдання вихователя дошкільного закладу - частіше звертатися до народних джерел у вихованні дітей. Для дошкільних закладів розроблено програми з українського народознавства, якими передбачено прилучення дітей з раннього віку до витоків народної культури. Видаються посібники для майбутніх спеціалістів у галузі дошкільної освіти, в яких висвітлюються методичні засади ознайомлення найменших громадян України 3 національними традиціями, звичаями, оберегами тощо [2].

На сучасному етапі проблемі ознайомлення дошкільників з народною іграшкою приділяють свою увагу такі науковці, як А. М. Богуш, Н. С. Буркун, Г. У. Григоренко, Н. Я. Дзюбина-Мельник, Г. В. Довженюк, Н.В.Лисенко, О. С. Найден, Т. І. Поніманська, М. Г. Стельмахович та інші.

Значення народної іграшки в житті дитини обумовлюється наступними положеннями:

- іграшка розвиває емоційну сферу особистості дошкільника;

- сприяє активізації процесу оволодіння знаннями, які включають етнохудожній та етнокультурний компоненти;

- формує вміння, навички творчої діяльності, а також сприяє фрормуванню ціннісного відношення до навколишньої дійсності [3].

Питання формування ціннісного ставлення у дошкільників неодноразово було піднято у працях науковців і практиків, але проблема формування ціннісного ставлення до народної іграшки сучасними засобами в умовах суспільного дошкільного виховання залишається менш вивченою. Особливості такого ставлення дошкільників до народної іграшки взагалі не вивчались.

Мета наукової роботи полягає у розробці теоретичних та прикладних аспектів цілеспрямованого педагогічного впливу на особистість дошкільника засобами використання народної іграшки.

Дослідження особливостей ціннісного ставлення дошкільників до народної іграшки вимагає поступового, обдуманого підходу. Так, нами було виокремлено три компоненти такого ставлення дошкільників: когнітивний, емоційний та поведінковий.

У своєму дослідженні ми розробили діагностичні завдання, які допомогли встановити рівень ціннісного ставлення дошкільників до народної іграшки за трьома описаними компонентами.

У результаті проведеного дослідження, нами з'ясовано, що у дітей старшого дошкільного віку переважає низький рівень ціннісного ставлення до народної іграшки (54 \%), середній рівень демонструють 38 \% дошкільників, високий - всього $8 \%$.

3 метою реалізації поставлених завдань нами була розроблена система роботи з дітьми старшого дошкільного віку.

Результативному ознайомленню дошкільнят з українською народною іграшкою сприяло дотримання системи, яка передбачає наступність пізнавальних завдань і становить три послідовних етапи: 
Перший етап. Завдання: викликати позитивне емоційне ставлення дошкільників до народної іграшки, збудити зацікавлення, замилування нею, спираючись на притаманне дітям цього віку сприймання близького їм світу казок, природи, навколишніх предметів.

Другий етап. Завдання: поглиблено знайомити дітей з видами народних іграшок як об'єктами декоративно-вжиткового мистецтва, спираючись на їхній попередній емоційний досвід. На цьому етапі дошкільнята довідуються про історію промислів, про народних майстрів, технологію виготовлення іграшок, особливості елементів і колориту оздоблення, оволодівають практичними вміннями.

Третій етап. Завдання: забезпечити умови для творчого самовираження дітей у предметній діяльності (малюванні, ліпленні, аплікації). Дати змогу творити за власними уподобаннями, послуговуючись набутим емоційним досвідом і знаннями художніх особливостей українських народних іграшок

Дослідження надало змогу визначити педагогічні умови формування у старших дошкільників ціннісного ставлення до національної культури, що забезпечили ефективність формувального експерименту, а саме:

- збагачення знань дітей, педагогів і батьків про народні українські іграшки;

- використання в роботі з дітьми таких інноваційних технологій, як колекціонування (Автор - В. Харматова); психолого-педагогічне проектування взаємодії дорослого і дитини (Автор - Т. Піроженко); використання схем-моделей для навчання дітей описових розповідей (Автор - Т. Ткаченко); розвиток творчих здібностей на заняттях 3 малювання (Автор - Л. Шульга), а в роботі з педагогами - робота у творчих групах, вивчення досвіду, майстер-класи, семінари-практикуми тощо;

- набуття дітьми навичок виготовлення народних іграшок 3 різного природного матеріалу та за допомогою різних технік;

— формування поваги й інтересу до культурної спадщини;

- облаштування виховного середовища, у якому сконцентровано різноманітні народні іграшки.

Для систематичного та планомірного введення дітей у світ національної культури, для їх духовно-морального розвитку та формування ціннісного ставлення старших дошкільників до народної іграшки ми збагатили предметно-ігрове розвивальне середовище осередками народознавчого спрямування та винесли рекомендації щодо наявності таких складових: етнографічний куточок, народознавча ігротека, зона театральної діяльності, тематична бібліотека та куточок зображувальної творчості.

Така організація предметно-ігрового розвивального середовища дає дітям змогу закріплювати набуті знання в самостійній ігровій та продуктивній діяльності, обираючи улюблені ігри та заняття.

Кожне проведене заняття передбачало організацію різних видів діяльності: комунікативної, пізнавальної, перетворювальної, оцінно-контрольної. Заняття обов'язково передбачали також практичну діяльність дітей, яка знаходила своє вираження в дитячих малюнках, таночках, вигаданих дітьми власних казках. Такі заняття пробуджували в дітей творчу активність, сприяли вдосконаленню образного мислення та зв'язного мовлення. 
Значно пожвавлювало роботу і викликало в дітей позитивні емоції та радісний настрій використання сюрпризних моментів, цікавих розповідей, загадок, прислів'їв, віршів, пісень тощо.

Одержані знання діти застосовували як у організованій вихователем, так i у вільній діяльності. Під час малювання, ліплення, аплікації, художньої праці, музичної діяльності вони відображали їх у творчих виробах, виконаних у різних техніках за власним вибором. Зокрема у творчій майстерні дошкільники: виготовляли ляльки-мотанки; глиняні іграшки; трав'яні іграшки; іграшки з тіста; прикрашали дерев'яні іграшки.

Порівнюючи зміни, які відбулися у ціннісному ставленні дошкільників до народної іграшки на початку дослідження і в кінці, можна говорити про достатньо високу ефективність проведеного експерименту. Так, суттєво змінилась кількість дітей, які демонстрували низький рівень прояву ціннісного ставлення дошкільників до народної іграшки (з 54 \% на 12 \%), більше стало дошкільників з середнім рівнем (з $38 \%$ на $68 \%$ ), відбулися зміни і у показниках високого рівня (з 8 \% на 20 \%). Результати контрольного експерименту надають підстави вважати, що теоретичне підґрунтя дослідження обрано вірно.

Здійснене дослідження не вичерпує означену проблему. Подальшого вивчення вимагають питання інтеграції засобів фрормування ціннісного ставлення старших дошкільників до української народної іграшки в родинну, шкільну та позашкільну царини виховання, удосконалення підготовки студентів педагогічних училищ, коледжів, ВН3 до формування ціннісного ставлення до національної культури у дітей інших вікових груп.

\section{Список використаних джерел:}

1. Геворкян, Н. (2008). Народна іграшка - дорогоцінна спадщина українських дітей. Дитячий садок. (15), 12 - 14.

2. Кільова, Г. (2010). Народна іграшка як засіб виховання дітей. Рідна школа. (6), 59 - 63.

3. Пазуха, А. (2011). У світ дитини - через гру. Дитячий садок. (9), 4 - 6. 


\title{
АВТОМАТИЗАЦІЯ БІБЛІОТЕЧНО-БІБЛІОГРАФІЧНИХ ПРОЦЕСІВ
}

\begin{abstract}
Малюк Ольга Юріївна
канд. фрілол. наук, доцент, доцент кафедри документознавства та інформаційної діяльності ДЗ «Луганський національний університет імені Тараса Шевченка»
\end{abstract}

УКРАЇHA

Відповідно до потреб часу бібліотеки поступово перетворюються із організацій, фрункцією яких $€$ збереження опублікованих документів i організація їх використання, у своєрідні інфрормаційні центри, які активно підкоряють Інтернет-простір [1].

Організаційним змінам бібліотек сприяють нові інформаційні технології, з упровадженням яких публічні бібліотеки дотримують стратегії переходу від традиційної книгозбірні до динамічного центру інфрормації. Вони активно створюють власні інформаційні ресурси, заповнюючи український сегмент в Інтернеті, утворюючи у своїй структурі ланки управління цими нововведеннями [2].

Метою автоматизації є підвищення продуктивності й ефективності праці, поліпшення якості інформаційної продукції й послуг, усунення одноманітних трудомістких і монотонних операцій.

Автоматизація бібліотечно-бібліографічних процесів у бібліотеці ставить такі цілі: скорочення часу на виконання технологічних операцій, пов'язаних 3 комплектуванням, організацією й використанням фондів і БД, довідковоінформаційним обслуговуванням i інформаційним забезпеченням користувачів системи; розширення складу надаваних користувачам послуг, зокрема, шляхом включення в роботу бібліотек нетрадиційних для них послуг інфрормаційного забезпечення й довідкового обслуговування, пов'язаних 3 підготовкою, веденням і оперативним наданням фрактографрічної інформації; підвищення комфортності роботи користувачів, персоналу бібліотеки; розширення можливостей бібліотечного й бібліографрічного обслуговування; сукупність всіх зазначених цілей.

Для проведення комплексних змін технологічного середовища необхідні сучасне програмне і технічне забезпечення, підготовлений до змін персонал $\mathrm{i}$, безумовно, заздалегідь спланована і ретельно обміркована організація роботи по створенню нової технології бібліотечних процесів. Варто навести слова професора Я. Л. Шрайберга, який сказав: „...автоматизація бібліотечноінфрормаційної діяльності - це прояв не лише сучасного науково-технічного розвитку, а й соціального прогресу: забезпечується не лише своєчасний й швидкий доступ користувачів до інформації та першоджерел, але в цілому створюються умови для реалізації одного з головних принципів відкритого суспільства - принципу загальної доступності інформації та публікацій" [3]. 
3 урахуванням постійного розвитку соціальних комунікацій під впливом ускладнення процесів у соціумі зростають вимоги до широкого застосування АБІС, до спеціалізації цих систем для вирішення проблем ефеективного інформаційного забезпечення потреб науки, культури, освіти, інших сфер суспільної діяльності. Специфіка автоматизації роботи бібліотек як оновлених загальносуспільних банків даних потребує подальших досліджень у контексті розширення можливостей використання інформаційних ресурсів. Отже, аналіз вимог, що висуваються сьогодні до АБІС, свідчить, що для ефективної роботи потрібні системи, створені з використанням інноваційних технічних рішень і засобів. Серед них насамперед варто виокремити триланкову побудову "клієнт - сервер інфрормації - система управління баз даних (СУБД)" із застосуванням веб-технологій. Цей програмний продукт має такі споживчі якості: - високу безпеку; - надійність, стійкість до аварій; - легку масштабованість і розширюваність; - використання позитивного досвіду розроблення та експлуатації АБІС попередніх поколінь, забезпечення наступності - передавання до нової системи результатів попередньої бібліотечної діяльності: бібліографічних БД, повнотекстових масивів, БД користувачів та інших нагромаджених масивів із максимальним використанням механізмів автоматичної конвертації [4].

Практика показала, що в процесі автоматизації керівництву бібліотеки необхідно виділити такі аспекти:

- прийняття рішення та розробка проекту автоматизації;

- створення функкіонального підрозділу, відповідального за хід автоматизації;

- вивчення досвіду автоматизації інших бібліотек;

- здійснення поетапного навчання співробітників;

- визначення технологічної і технічної бази;

- створення локальної бібліотечної мережі;

- можливість комп'ютерного обміну інформацією між бібліотеками;

- формування власних БД [5].

Виходячи з набутого досвіду, підсумуємо, що впровадження автоматизації в бібліотеках має три рухомі сили:

Державна політика, спрямована на інформатизацію суспільства. Користувачі, які вимагають більш повної та якісної інформації. Сучасна бібліотека, яка прагне задовольнити ці потреби, не може існувати лише за рахунок власного інформаційного потенціалу, тому виникає потреба взаємодії у створенні і використанні загальних інформаційних ресурсів. Внутрішні причини: збільшення інформаційного потоку, трудомісткість ручної обробки. Бібліотекам необхідне швидке забезпечення інформацією споживача, тому що з часом велика кількість інформації втрачає свою актуальність [5].

\section{Список використаних джерел:}

1. Курило, Н. (2016). Сучасна бібліотека освітнього закладу очима студентів. Документноінфформаційні комунікації в умовах глобалізації: стан, проблеми і перспективи: матеріали II Всеукраїнської науково-практичної Інтернет-конфреренції . 23 листопада, 2016, Полтава, Україна.

2. Вилегжаніна, Т. (2009). Інновації - визначальний фактор розвитку бібліотек України. Бібліотечна планета, (1), 6-9. 
3. Шрайберг, Я. Л. (2001). Основные положения и принципы разработки автоматизированных библиотечно-информационных систем и сетей: главные тенденции окружения, основные положения и предпосылки, базовые принципы. Москва: Либерея.

4. Медведєва, Валентина. (2015). Інноваційні технології - майбутнє бібліотеки. Вісник Книжкової палати, (8), 28-32.

5. Посвистак О. (2005) Інформаційний простір бібліотеки: нові технологї - нові можливості. Персонал, (4), 42-45. Вилучено із http://personal.in.ua/article.php?ida

DOI 10.36074/13.12.2019.v3.02

\section{РОЛЬ ІННОВАЦІЙНОЇ СПІВПРАЦІ РЕСТОРАННОГО БІЗНЕСУ ТА КУЛЬТУРНОГО ТУРИЗМУ В ОТРИМАННІ КРЕАТИВНОГО ТУРИСТИЧНОГО ДОСВІДУ}

ORCID 0000-0003-4771-4521

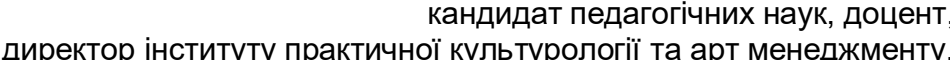
Національної академі керівних кадрів культури і мистецтв

ORCID 0000-0001-6187-6215
Іванов Сергій Віталійович

доктор хімічних наук, профресор, перший проректор з науково-педагогічної роботи, Національна академія керівних кадрів культури і мистецтв

УКРАЇHA

У світі щорічно проходять сотні гастрономічних фестивалів, присвячених різним продуктам, їжі і напоїв. Їжа і гастрономія можуть самі по собі вважатися креативними індустріями, які стимулюють інновації, залучаючи споживача в спільну творчість, зміцнюючи зв'язок між глобальними і локальними культурами і створюючи легенди про їжу. Сьогодні багато інноваційних процесів, що відбуваються навколо їжі, гастрономії, ресторанного бізнесу та культурного туризму, пов'язані 3 креативним туристичним досвідом, гастрономічними заходами, гастрономічними маршрутами і знайомством 3 новими кухнями [1].

Одним з найбільш перспективних напрямів інноваційної діяльності в культурному туризмі $є$ досвід створення зв'язків між глобальними та місцевими культурами, що позитивно інтегрує виробництво продуктів харчування 3 мистецтвом та іншими культурними ініціативами, такими як винні заводи, музеї, винні льохи, виставки інноваційних графічних етикеток від місцевих або міжнародних художників і різноманітні гастрономічні подієві заходи з музикою і художніми виставами. Щорічно в кінці літа на острові Уайт (Великобританія) проходить Часниковий фестиваль, який започаткував місцевий фермер - Колін Босуелл. Фестиваль швидко завоював серця місцевих жителів, а незабаром його стали відвідувати туристи. Сьогодні вони з'їжджаються з усіх куточків 
планети, щоб послухати гарну музику і насолодитися всілякими стравами 3 часнику, в тому числі вишуканими і оригінальними. Гостям пропонуються як традиційні страви - супи, соуси, соління, пироги, так і незвичайні - часникове пиво і навіть морозиво зі смаком часнику [2]. Гастрономія є ключовою частиною всіх культур і в даний час відіграє важливу роль у досвіді туризму. Туристи все частіше шукають контакт з місцевими жителями і їх життям, досвід приготування національної їжі, стимулюючи вироблення відмінних продуктів, розвиток інфраструктури для виробництва та споживання харчових продуктів і підтримки місцеві культурні традиції. У цьому процесі гастрономія дозволяє відвідувачам створювати, а не споживати. Локальна територія $€$ основою гастрономічних пропозицій це елемент, який $\epsilon$ джерелом місцевої ідентичності. Вона включає в себе ландшафт, навколишнє середовище, історію, культуру, традиції. 3 цієї точки зору, перетворення території в кулінарний ландшафт - одне із завдань туристичного напрямку. Важливо визначити, які природні та культурні ресурси можна перетворити в туристичний продукт, за яким можна буде ідентифікувати територію. Ніяка туристська гастрономічна пропозиція не буде життєздатною, якщо вона не здатне враховувати культурні особливості території. Гастрономія дозволяє туристам отримати доступ до культурної та історичної спадщини, наблизитися до культури дослідним шляхом, а не просто через споглядання.

В Австрії за основу розвитку місцевої економіки був узятий підхід інтеграції туризму і сільського господарства. Країна має репутацію «гастрономічного магазину Європи» завдяки великій кількості екологічно чистих ферм. Цікавим $\epsilon$ той фракт, що з 137 тис. австрійських ферм 8\% зайняті в сфрері туризму, надаючи мандрівникам можливість проживати, працювати, харчуватися на фермі згідно австрійським традиціям і придбати екологічно чисті продукти харчування. Гірськолижні курорти також активно взаємодіють з місцевими фермерами і використовують їх харчову продукцію [3].

Гастрономічні туристи, які беруть участь в новій тенденції культурного споживання, досліджують автентичність місця через їжу. Вони зацікавлені походженням продуктів, визнають цінність гастрономії як засіб обміну досвідом. Такі туристи мають дохід вище середнього, добре розбираються в їжі і вимогливі до неї. Для таких туристів гастрономія не може бути прісною i анонімної, вона повинна мати індивідуальність, тому що інакше гастрономічна продукція стане вразливою, делокалізованою і буде вважатися предметом фальсифрікації. Дуже яскравою ілюстрацією використання гастрономічних пропозицій може бути американський досвід маленьких міст (15 - 20 тис. мешканців). Кожне американське місто намагається хоч якось продемонструвати свою особистість. Практично кожне американське місто має своє лого, свою назву, свій девіз, додатково до офіційної. Штат Вісконсин, місто Сеймур - гордо називає себе Батьківщиною гамбургера. Місто Франкемурт, Мічіган - маленька Баварія Мічігану. Місто Мортон, Іллінойс гарбузова столиця світу [4]. Кожне з цих міст намагається привернути туристів ще й цікавими закладами готельно-ресторанного бізнесу.

Одним з незвичайних прикладів використання гастрономічного компонента в туризмі $є$ комуна Восс на заході Норвегії, яка спеціалізується на виробництві молока і м'ясної продукції, одержуваних від овець і рогатої худоби. Туристам 
пропонується традиційне нордичне блюдо «Smalahove» - солона, копчена i варена голова вівці, яка при подачі розділяється на дві половини. Блюдо має давню історію, яка починається $31300-x$ років. Цікаво, що трапеза супроводжується розповідями про страву і традиції, новачкам пояснюються правила поведінки під час трапези, гостям також пропонується відвідати ферму і місцеву пивоварню. Навколо цієї страви побудовано виготовлення сувенірної продукції: різноманітні прикраси, столове приладдя, келихи із зображенням голови вівці, збірники пісень овечої голови, комікси. В результаті традиційне блюдо стало основою сучасної туристичної концепції дестинації і дозволило зміцнити позиції комуни на ринку туристичних послуг [53 1998 року в Восс проводиться дводенний «Фестиваль звільнення овечої голови», під час якого влаштовується велика кількість заходів.

Сприйняття їжі як свята смаку і обов'язкове отримання задоволення від її приготування і споживання під час трапези в приємній компанії стало однієї 3 цілей громадського руху «Slow Food» («їжа без поспіху»). У разі трапези поза домом критерієм вибору ресторану є використання тільки свіжих натуральних продуктів і відсутність на кухні напівфабрикатів [6]. Засновником руху став журналіст і кулінарний критик Карло Петрина (Carlo Petrini), який був прихильником збереження кулінарних традицій своєї країни. У мережі «слоуфруд» розроблена і втілюється на практиці програма підтримки сімейних ферм, компаній, що вирощують екологічно чисті продукти для приготування здорової їжі. Задля цього проводяться навчальні семінари, конференції в різних країнах світу, міжнародні ярмарки виробників і постачальників екологічно чистих продуктів.

У межах pyxy Slow Food створена лабораторія Смаку, яка проводить різні заходи 3 метою знайомства із традиційними технологіями продуктів харчування і особливостями традиційних рецептів, популяризації унікальних страв. Одним із найважливіших напрямків діяльності «Slow Food» $€$ створення своєрідної «червоної книги їжі» «Ковчега смаку», яка містить перелік із 800 унікальних продуктів та страв, які знаходяться на межі зникнення, з більш ніж 50 країн світу. У місті Турині (Італія) восени раз на два роки проходять форуми «Terra Madre» (Мати-Земля), де представлені національні продукти харчування з усього світу, вирощені згідно з традиційними технологіями i переважно фермерськими господарствами.

Наукова комісія «Ковчегу Смаку» знаходить і реєструє рідкісні продукти, рослини, керуючись критеріями: унікальний смак, зв'язок із територією, традиційність виробництва і його непромисловий характер, ризик зникнення. У межах цього проекту всі бажаючі можуть пропонувати традиційні рецепти, продукти, сорти і породи, яким загрожує знищення й забутяя і які є своєрідними гастрономічними брендами. Завдяки наявності гастрономічних брендів, територія отримує додаткову популярність, а брендові продукти стають невід'ємною частиною іміджу конкретної місцевості. Так, Франція та Італія внесли кілька сотень продуктів, серед яких сири - камамбер, комте, «Блюд'Овернь», моцарелла, горгонцола, а також Пармську шинку й бальзамічний оцет. Греки захистили 20 видів сирів; португальці - 12, а крім того, мед і оливкову олію; австрійці - шинку з Тіролю; бельгійці - багато видів пива та масло з Арденських гір; іспанці - свою спаржу, мед і шафрран; мешканці 
Великобританії - шотландську баранину, уельську телятину та кетське пиво; люксембуржці - трояндову олію; поляки -вид червоних гірських корів, що живуть тільки у Малопольщі, осщипки (вид копченого сиру з молока овець) та питний мед.

Від України представлені лише п'ять найменувань нашої спадщини, і ще 13 номіновані, серед яких «поліський мацик» («український хамон»), гуцульський копчений сир будз, ялтинську цибулю, кримське вино, місцеві сорти яблук та кизилу, рахівський сир (бринза), панір із молока карпатських буйволиць. [7]. В нашій країні Slow Food бере участь в таких «смачних» заходах як Best Food Fest, фестиваль «Борщ в горщик» в Опішні (Полтавської область), різних артпікніках. [8]. Ці заходи впливають на формування бренду туристських регіонів, тому дуже важливо визначити традиційні та природні ресурси, які будуть перетворені в туристські продукти, які зможуть асоціюватися з тим чи іншим регіоном. Тому брендинг об'єктів культурної спадщини може будуватися через призму культури харчування в стратегії залучення різних цільових аудиторій. Виробники продуктів харчування різними способами використовують інтерес споживачів до їжі, що асоціюється з профілем регіону. Вони можуть виробляти продукти харчування в самому регіоні або створювати відчуття автентичності

Висновки. Серед складових гастрономічного бренду: добре розвинена сорера гастрономії; енергійне гастрономічне співтовариство з традиційними ресторанами і кухарями; місцеві інгредієнти, використовувані в традиційній кухні; місцеве ноу-хау в кулінарії; традиційні продовольчі ринки і харчова промисловість; гастрономічні фестивалі, нагороди, конкурси; просування гастрономії в освітні установи. Так, наприклад, сьогодні Швеція стала просувати себе як один з центрів гастрономічного туризму, в тому числі ця країна почала формування свого гастрономічного бренду за допомогою інноваційного проекту «Швеція - нова кулінарна нація», що просувається через офріси компанії VisitSweden, розташовані в 12 країнах світу. В кожній країні $\epsilon$ регіональні відмінності в місцевій кухні, свій неповторний набір страв і технологій їх приготування, а отже, $є$ і потенціал для розвитку гастрономічного бренду.

\section{Список використаних джерел:}

1. Грег, Ричардс «Еда и туристский опыт». (2012). Журнал UNWTO: Global Report on Food Tourism, 20-21.

2. Гастрономический туризм: современные тенденции и перспективы. Драчева Е.Л.,Христов Т.Т. Изъято из http://futureruss.ru/wp-content/uploads/2015/08/ХристовДрачева-.pdf

3. Mulcahy J. Gastronomic Tourism as an Economic Driver in Ireland, Promoted and Practiced by Government, Business, and Civil Society. Retrieved from http://arrow.dit.ie/cgi/ viewcontent.cgi?article $=1022 \&$ context $=$ dgs

4. Зотова, Л.Р. (2015). Креативный город: творческие индустрии и развитие городов. Креативная экономика. Изъято из doi: 10.18334/ce.9.11.2085.

5. Gyimóthy, S., Mykletun R. Scary Food: Commodifying Culinary Heritage as Meal Adventures in Tourism // J. Vacat. Marketing. 2009. № 15(3). P. 259-273.

6. Slow Food Kiev. URL: http://slowfood.kiev.ua/o-slow-food.

7. Slow Food. Ковчег смаку чи вкуса. URL: http://slowfood.kiev.ua/o-slow-food/kovcheg-vkusa 


\title{
SECTION X.
}

PEDAGOGY

\section{CURRENT TRENDS IN GERMAN PRIMARY EDUCATION IN CONTEXT OF PRIMARY SCHOOL REFORM IN UKRAINE}

\author{
Alina Dzhurylo \\ $\mathrm{PhD}$, Senior Researcher of Comparative Education \\ Department Institute of Pedagogy \\ National Academy of Educational Sciences of Ukraine
}

UKRAINE

The challenge for changes in Ukrainian education system is the fact that today, unfortunately, school education as so primary school has ceased to meet the needs of modern young generation, it has become uninteresting and ineffective compared to European primary education. At the time, you need to change the approaches and format of training.

With the advent of interactive technology, total degitalization, teachers have expanded their options for learning. Using only textbooks, notebooks and a boards durring the lesson is gradually fading into the background. Nowadays there is a great gap between what the school can give to students and what the younger generation will be doing after graduation.

In light of this, high-quality logistical, methodological and software of the school combined with a competent approach is one of the leading conditions for the formation of a modern integrated educational environment of primary school. Today it is necessary not only to fill the heads of students with knowledge, but to form in the individual key competencies for success in life, to make the future graduate competitive in society.

Turning to the experience of European countries, we will see that their education has a similar goal for a long time. For example, in the "School Laws on Education" [1] of the Eastern Lands of Germany, this goal was formulated in the 1990s, after German unification. Training has become more practical, and the learning process itself has focused on the acquisition of learning and life skills by students.

After the reforms and modernization of education since the late 1980s and until today, Germany has a four-stage education system: elementary, two-level secondary education and higher. Nine years of schooling is compulsory for all children from six years of age. Public schooling is free. Typically, children teach in elementary school for four years (Grundschule). Only in Berlin and Brandenburg is the elementary school lasting 6 years (consequently, the training at the next levels lasts less).

Lessons in all classes are conducted according to the same program. During the first two years, all lessons are taught by a class master. There is no disciplinary structuring - basic knowledge of mathematics, German, local lore, music and 
religion is taught comprehensively, within one educational course. Beginning in third grade, the subject is taught by subject teachers.

At the end of primary school, students are advised in which of the three types of schools to continue their education (Hauptschule, Realschule, Gymnasium). The main difference between the first two schools from the gymnasium is that the curriculm there is easier, but the certificate of school attendance does not give the right to enter the university. Typically, primary classes exist within one secondary school (Allgemeineschule), where students who have completed primary education continue their education in secondary school (from 10-12 to 16 years) and secondary specialized school (from 16 to 19 years).

Leading and decisive role in the formation of personality plays the objective assessment of knowledge of primary school students. In Germany much attention is paid to the individualization, student's orientation and focusing on their capabilities. Therefore, the evaluation is differentiated. In most federal lands, children do not receive grades in the first two years of study, but only a general characteristic of achievement that gives information about individual strengths and weaknesses in the study of individual subjects.

Primary school assessment is an effective incentive, it is objectively and fairly presented, and all students have the same requirements. Performance scores are independent of other characteristics, such as students' behavior at and outside the school. In primary schools in Germany, since the third grade, academic performance is assessed by a six-point system: 1 (excellent), 2 (good), 3 (satisfactory), 4 (sufficient), 5 (bad), 6 (very poor).

Assessment is the only means at the teacher's disposal to stimulate learning, positive motivation, and influence on the individual. Primary school serves as a foundation for general school education. To improve learning outcomes, teachers recommend what and how a child should work. The year-end report shows the results of the child's mastery of the curriculum. During the evaluation, the following is taken into account: accomplishment of the planned tasks, cooperation in the lesson, maintenance of a workbook, acquisition of knowledge and skills.

In Germany the information about child's performance is presented for parents in a table indicating the level of mastering the main competences in all subjects. The so-called "Expanded Progress Report" is issued to parents twice as "interim report" (at the end of semester 1) and "annual report" (at the end of the year). With this kind of report from the teacher, it is easier for parents to keep track of the child's progress. In addition, all teachers and educators who teach in this class exhibit peer assessment for the following social indicators: behavior, teamwork, willingness to take responsibility, ability to resolve conflicts. For students who do not have time to absorb the learning material at the proper level, extra classes are organized in the afternoons. These can be individual or group lessons.

The analysis of curricula, the study of changes and features of German primary schools has showed the orientation of education to ensure the full development of the individual, the acquisition of primary education, which prepares for further education on the basis of integration.

Due to the reform of the German education system in the direction of improving its quality, a number of measures for improving the quality of the German general secondary education system were developed and implemented, which included: 
creation of national educational standards in the field of elementary and secondary education; developing a national concept for monitoring education; the opening of the Institute for Education Quality in Berlin.

\title{
References:
}

1. Kultusministerkonferenz. Schulgesetze der Länder in der Bundesrepublik Deutschland Retrieved 2019 from: https://www.kmk.org/dokumentation-statistik/rechtsvorschriftenlehrplaene/uebersicht-schulgesetze.html

DOI 10.36074/13.12.2019.v3.03

\section{SOME ASPECTS OF HISTORY OF THE MEDIA LITERACY MOVEMENT IN IN THE UNITED STATES OF AMERICA AND CANADA}

\author{
Nataliia Prykhodkina \\ $\mathrm{PhD}$ in Education, associate professor, doctoral candidate \\ Institute of Pedagogy of National academy of pedagogical scienses
}

UKRAINE

To understand the history of the Media Literacy Movement in the United States of America, it is necessary to appreciate the role of mass media, and especially television, in the United states as compared to other countries.

«The United States is almost alone in the world in giving preference to developing television as a commercial medium rather than as a public service» (2, p. 115). «Most other countries take television as a medium much more seriously, and accept some form of government control over the medium» [1]. In most European countries television is seen as a medium to be used for public education and information. In the Scandinavian countries, «the government holds a monopoly on broadcasting" and «there is no advertising» [1]. In the United States, commercial television stations usually have less than one hour per week of informative children's programming and public television provides about 27 hours of children's television per week. In all Western European countries, just as in the United States, public television stations are committed to high quality television programming for children; however, commercial stations are also more committed to serving children than commercial stations in the United States.

Marvin Kittman denounces the way news programs have evolved in the United States. He points out that they were originally established as part of the station's obligation in order to receive a broadcasting license, and contends that it is unconscionable that any profit be involved in news broadcasting [3].

Organizations for the advancement of media literacy are currently flourishing. There is obviously a vast need for support for teachers, parents, and communities for literature on how to deal with the encroaching level of mass media's intrusion 
into our children's lives and resource materials to aid in teaching the concepts of media literacy.

The Media Literacy Movement in Canada is thriving. In 1987, Ontario was the first educational body in North America to mandate the teaching of Media Literacy as part of the revised Language Arts Curriculum for junior and senior secondary students [4]. This was a result of many public and parent groups pressuring the school system to respond to the expansion of violence and pornography in the media [5].

But John J. Pungente, one of the writers of the official Ontario Department of Education's Resource Guide, wants to stop the television bashing and to look for what might be there that is significant. He reminds us that even though the media attempt to inculcate values with which we may disagree (e.g., "the idea that everything can be purchased and that consumption is an intrinsic good»), television has often contributed many positive programs (such as those that have incorporated classical music or documentaries such as PBS's The Civil War), covered events in different parts of the world that we otherwise would not witness, and educated the public about health (AIDS) and social issues ("Live Aid», which raised over $\$ 110$ million in donations for famine relief in Africa). He feels that the best way to play an active part in improving television is to seek out, acknowledge, and support its most important and impressive efforts, and if we can have a generation of viewers who are media literate they «can and will demand change in television» [4].

In Canada, provinces and territories each have their own education system, so each one deals with media literacy in a different way [5]. In Western Canada in 1991 the Canadian Association for Media Education (CAME) was formed. Its members are classroom teachers and other organizations (such as the National Film Board of Canada and ADBUSTERS magazine). "Their objectives are to educate Canadians about the media, to promote media literacy and to encourage Canadian cultural expression in the media" [5]. They hold yearly forums and bring in prominent speakers such as Len Masterman and George Gerbner to speak to parents and teachers. One of their projects was to help blend media literacy into all curriculum areas. The province of Saskatchewan has also made great strides in the field of media literacy.

They have developed a Media Literacy guide that extends from primary through to the end of secondary school, so that Media Literacy can be integrated with any and all aspects of the school curriculum from the earliest years of school to its completion.

\section{References:}

1. Hesse, P. \& Wardly, V. (2006) Media Literacy Education: How to Turn Children into Critical Consumers of the Media. Wheelock College, Boston, MAJ.

2. Huston, A., Donnerstein, E. \& Fairchild, H. (1992) Big World. Small Screen. The Role of Television in American Society. Lincoln, Nebraska: $U$ of Nebraska.

3. Kittman, M. (1999) On the Media. National Public Radio. Retrieved from: https://www.thenation.com/article/on-the-media/

4. Pungente, J. Signs and Symbols of the Transcendent: Revisiting Our Media. 2015. Retrieved from: http://interact.uoregon.edujmedialitja

5. Pungente, J. The Second Spring: Media Literacy in Canada's Schools. Retrieved from: http://interact.uoregon.edu/MediaLit/FA/MLArticleFolderjsecondspring.html 


\section{SPECIFICS OF WORK WITH CHILDREN OF PRESCHOOL AGE (IN PARTICULAR AUTISM)}

Viktoria Pigareva

group of compensating type for children with mental retardation g. Belgorod.

The senior tutor of the preparatory group №10 «Podsolnushki»

MBDOU № 15 «Friendly family»

RUSSIAN FEDERATION

Autism is a condition associated primarily with communication difficulties: it has a specific impact on the communication of an autistic person with other people and his attitude to them. Children with autism spectrum disorder have difficulty building relationships with loved ones and strangers, including peers, because they have a limited capacity for friendship, as well as understanding the emotions of another person. Thus, even a highly functional autistic person most often faces problems in the areas of:

1) social interaction;

2) social communication;

3) social imagination.

Qualified school teachers and kindergarten teachers are familiar with the algorithms for including special students in a class or kindergarten group of neurotypical children. In this case, it is mainly about children with learning difficulties and / or children with disabilities (intellectual, emotional, physical disabilities). However, the "painless" inclusion of an autistic student in a group, as well as the correct support and productive training of such a student, often become serious problems, sometimes baffling even the most experienced teachers and educators.

RULES FOR WORKING WITH CHILDREN WITH SIMILAR DISORDERS

Although each little autistic is unique in its own way, stereotypical behavior and basic nuances that impede social communication are typical of all children with ASD. Accordingly, in parallel with the usual General education classes with such students, steps such as:

1) encouraging socially acceptable interaction and contact with other students;

2) feasible mitigation of various pathological symptoms in the behavior and perception of the student.

So, teaching an autistic child among ordinary children should help him to adapt in a team and develop socialization skills. People with ASD who attended kindergarten and school with neurotypical children, in the future it is much easier to feel like full members of society than former students of correctional school. It should be noted that the process of socialization is much easier and faster if in parallel the child is engaged in the method of ABA (applied behavioral analysis) - not only with a specialized specialist, but also at home with parents. Also effective are applied learning materials-visual schedule for autistic, games, cards.

RULES OF WORK IN KINDERGARTEN:

An autistic child of preschool age (4-5 years), finding himself in kindergarten, often shows problems with adaptation, characteristic of neurotypical children of the 
nursery group. He can become very attached to the caregiver or nanny, trying to constantly maintain tactile contact with her-to hold her hand or sit on her lap.

One of the typical problems of young autistic children is the development of "regime" kindergarten activities, such as daytime sleep, food, going to the toilet. Sometimes the child who normally ate at home and coped with the pot, in kindergarten begins to refuse food and/or he begins enuresis (and in some cases he can just endure all day without visiting the toilet).

Of course, the baby is experiencing difficulties with entering a group of peers, especially at first. He does not join the General games on his own, does not show interest in classes. However, it often turns out that "absent" externally, the child can perceive what is happening well: for example, at home he can sing a song learned in kindergarten, although he did not even try to sing at the music hour.

To adapt more successfully, you can not give a little autistic in the garden "suddenly". First, walk with him on a walk through the territory of his future garden, see together how children play there. In this case, you need to tell the baby in detail about the upcoming classes in the garden, the mode of the day, the time when parents will come for him. In the first weeks or even months, the child should be brought to the group for a short time, gradually increasing the time of his stay there. Also help and educational toys for autistic children who are taught to contact other people.

HOW TO HELP AN AUTISTIC CHILD ADAPT IN KINDERGARTEN

Reasoning how to work with an autistic child "simple" teacher, you must initially understand that the habituation of such a child to the team - quite a painstaking process that requires joint efforts not only kindergarten or school workers, but also the parents of the student, because he constantly needs additional attention. Accordingly, the correct approach to how to work with an autistic teacher or educator should be based on various special techniques and methods aimed at accelerating the adaptation of the autistic student in the team.

\section{VISUAL COMMUNICATIONS}

Since most children with autism have a tendency to visual thinking, it is much easier for them to perceive information a) fragmented into small "portions", b) in a visual form. So, a very effective method will be a visual (illustrated) schedule, allowing the student to always understand what will happen next. This method can be used both in school or kindergarten, and in a circle or section.

\section{SUPPORT}

Working with autistic children in kindergarten or school should necessarily include helping the autistic student to understand the meaning of everything that happens during the kindergarten day. To do this, you need to separately tell him all the actions and events that are happening at the moment or are planned. For example, in kindergarten: "Now all the children will start to have lunch, and you will also have lunch. Then there will be a quiet hour, we will rest, and when we rest we will play, draw, go for a walk, etc." For any autistic person, it is very important to know what to expect, because such information calms him and he feels safe, whereas the unknown is very frightening and literally "knocks the ground out from under his feet".

Touch games. 
Identifying some of the individual characteristics of the baby can greatly simplify the understanding of how to work with autistic children educator in kindergarten. For example, if the caregiver notices that the duckling likes to spend time alone, pouring sand, pouring water, etc. - you can use these features to establish interaction with the baby. For example, together to play with sand or grits, "to hide" in them small toys that the child found them, to paint water in different colors.

Such interaction is a "shared experience", which helps not only to establish contact, but also to create a basis for "shared attention" - and on its basis, then a joint activity with the rest of the children will be built.

GAME ACTIVITY:

A child with RAS is not interested in sensory games, but he likes to mess with objects that have similar characteristics. This activity can also be made developing, giving it some meaning and expanding its boundaries. For example, if the baby puts a row of rings from the pyramid-sit down and start to make rows of identical objects that do not look like rings (cubes, pictures, dolls, etc.). Gradually, you need to add to their ranks some simple, but meaningful stories: for example, putting the cars one after the other, to portray a traveling train.

As a result, the more sense it will be possible to "build up" on the stereotypical game, the faster the symptoms of stereotypy will soften, because the child will no longer just thoughtlessly put objects in a row, but will try to achieve a certain result - to make a train, etc.

CONTACT WITH OTHER CHILDREN

Correct work with autistic children in school or kindergarten is impossible without the help of the teacher in establishing contact with other students. It is necessary to try very delicately and amiably to involve the child with RACES in General occupations or games, preventing possible episodes of aggression or inadequacy.

At the same time, simply suppressing unwanted behavior is not enough: it is necessary to kindly and unobtrusively teach an autistic person to interact with children in a more "correct" and socially acceptable way. For example: "you Can not take away the ball (pencil, book) without asking. You have to ask, "let me play with the ball," etc.

\section{References:}

1. Alvin, Juliet (2008). Music therapy for children with autism. Moscow: Terevinf.

2. Appe, Francesca (2011). Introduction to the psychological theory of autism. Moscow: Charity Fund "Terevinf".

3. Gilbert, K. (2008). Autism. Medical and pedagogical impact. Moscow: Book on Demand.

4. Greenspan, Stanley (2013). On you with autism. Using Floortime techniques to develop relationships, communication and thinking. Moscow: Terevinf.

5. Gray, John (2010). Children are from heaven. The gift of autism (set of 2 books). Moscow: IG "All", Sofia.

6. Gray, John (2010). Children are from heaven. Soul in soul. The gift of autism (set of 3 books). Moscow: Sofia, IG "All". 
DOI 10.36074/13.12.2019.v3.04

\title{
TEACHING COMMUNICATIVE GRAMMAR TO FUTURE ENGINEERS
}

\begin{abstract}
Alina Kotkovets
National Technical University of Ukraine «lgor Sikorsky Kyiv Polytechnic Institute»

Olena Leonova

National Technical University of Ukraine «lgor Sikorsky Kyiv Polytechnic Institute»

UKRAINE
\end{abstract}

Nowadays, the modern labour market is getting more and more competitive due to a number of reasons, such as the global processes of digitalisation and internalisation. The aim of the higher education institutions is therefore to facilitate the formation of the specialist who is able to adapt to the changes in the professional sphere. Knowing a foreign language, English in particular, is today a must for any employee. The ability to communicate in English is made up of a number of competences, grammatical one is among them. Students of technical specialities will not only have to deal with specific vocabulary in their professional communication but they also have to be aware of the typical grammatical items. However, the question of how grammar should be taught has always been rather controversial.

As S. Thornbury defines it, "grammar is a description of the rules that govern how a language's sentences are formed" [4]. Traditional teaching of a foreign language grammar was about memorising these rules and knowing all the terms connected to them as well as their equivalents in the mother tongue. This knowledge however does not guarantee the ability to use them in communication. Grammatical knowledge is only one of the components of the grammatical competence. As Ukrainian scholars Bihych, Borysko et al. put it, grammatical competence is the ability to grammatically correct arrange one's oral and written expressions and understand the grammatical arrangement of others' expressions; it is based on the system of grammatical knowledge, grammatical skills, and respective language awareness [1]. According to the Common European Framework of Reference for Languages, students are considered to be the users of the language and social agents, which makes the language a tool for communication, not a mere subject to study [2]. This leads to the need of abandoning a traditional grammar teaching approach. Teaching technical English to future engineers will mostly focus on the functional aspect of grammar and will be limited to the patterns that are typical in job-related contexts. Teaching grammatical structures communicatively in meaningful contexts can make a learning process more motivating and effective. It might be challenging though. There are various approaches to teaching grammar, each of them having benefits and drawbacks. Their appropriateness also depends on the grammatical topic which needs to be taught.

One of the ways of working with grammatical material while teaching English to future engineers following the presentation-practice-production model might have such structure. During the presentation stage of the inductive learning strategy, 
students may be exposed to a large number of targeted grammar items, the socalled comprehensible input. It can be a text or a dialogue they need to read or listen. For instance, the use of present perfect can be exemplified by the sentences taken from the open-access web-site article printed in 2017: "The year 2017 has catapulted us into a science-fiction future, from human cell regeneration for growing organs, to banishing genetic disease through breakthrough gene-editing techniques and recycling orbital rockets - and it's only August at the time of writing. A lot has happened in the last eight months; scientific breakthroughs have made our lives safer, easier and more enjoyable. Researchers and scientists around the globe have worked tirelessly to bring us this future, so it's worthwhile to take a step back and applaud their tremendous efforts" [3]. More samples can be offered. Students then may be asked to underline and identify the necessary structure and infer the rules of formation and use. The teacher should ask questions and make clarification to be sure the grammatical structure taught is understood. The stage of controlled practice may be in the form of various exercise, drills and activities, from the conventional gap-filling tasks to grammatical games. A relay race grammar game might be used as a drill, where students in teams take turns to write e.g. the correct form of the verb as fast as possible. A lot of ideas can be found on-line, for instance, the games like jeopardy, which a teacher only has to print and cut. Board games also have a great potential and are easy to organise and use. Learning apps and on-line games have also become an important part of the grammar learning/ teaching process. The stages of the freer practice and the production are aimed at developing students' ability to use the required grammatical structures in communication. The activities start from creating own sentences using patterns or cues and then move on to the composition of discourse (dialogues or texts). These steps can help make the introduction, training and use of grammatical structures more meaningful, memorable and useful.

To sum up, there are several approaches to teaching grammar, which may be combined to achieve the best results. The inductive learning of the grammatical structures (required in the job-related context) followed by teacher's guidance might be one of the ways to deal with teaching grammar to future engineers.

\section{References:}

1. Bihych, O. B., Borysko, N. F., Boretska, H. E. et al. (2013). Metodyka navchannya inozemnykh mov $i$ kultur: teoriya i praktyka [Methods of Teaching Languages and Cultures: Theory and Practice]. Kyiv. Lenvit. (in Ukrainian).

2. Council of Europe (2018). Common European Framework of Reference for Languages: Learning, teaching, assessment. The Companion Volume with New Descriptors. Retrieved December 9 , 2019, from https://rm.coe.int/cefr-companion-volume-with-new-descriptors-2018/1680787989.

3. Tangermann, V. (2018, August 8). Top 10 New Scientific Discoveries of the Year. Retrieved December 9, 2019, from https://futurism.com/the-most-significant-scientific-discoveries-of-theyear-so-far.

4. Thornbury, S. (1999). How to teach grammar. Harlow: Longman. 


\section{ВПЛИВ СОЦІАЛЬНИХ МЕРЕЖ НА МОЛОДШИХ ШКОЛЯРІВ} здобувач вищої освіти факультету дошкільної, початкової освіти і мистецтв Національний університет "Чернігівський колегіум» імені Т. Г. Шевченка

НАУКОВИЙ КЕРІВНИК:

Лимар Юлія Михайлівна

канд. пед. наук, доцент, доцент кафедри дошкільної та початкової освіти Національний університет «Чернігівський колегіум» імені Т.Г. Шевченка

УКРÄ̈HA

Питання впливу соціальних мереж на молодшого школяра $є$ дуже актуальним, але малодослідженим. Діти - це наше майбутнє і тому ми повинні дуже ретельно спостерігати за тим, що саме впливає на їхній розвиток і чим вони займаються у вільний час. На сьогоднішній день школярі дуже часто користуються всіма можливими соціальними мережами, але, на жаль, з цього виникає проблема адже ніхто не знає кого і що саме дитина зустріне на просторах Інтернету і як це вплине на її подальше життя.

Так, фахівці з Великобританії визначають соціальні мережі як веб-сайти чи інші інструменти Інтернету, котрі надають можливість користувачам взаємодіяти один з одним, обмінюючись інформацією [1]. Але діти це визначення розуміють по-своєму.

Нами було проведено анкетування, в якому взяли участь 28 учнів 4-го класу Чернігівської ЗОШ I ступеня № 25. Аналіз результатів анкетування свідчить, що учні мало проінформовані та не усвідомлюють значення для них соціальних мереж. Так, наприклад, більшість учнів написали: «Соціальні мережі - це місце де можна переписуватись з людьми». На запитання «Що ти знаєш про соціальні мережі?» більшість учнів відповідали одним словом «Нічого». Тільки троє з них відповіли: «в соціальних мережах існує багато обману та людей які можуть заподіяти зло».

На нашу думку, вчителі повинні ознайомлювати дітей з таким поняттям як «соціальні мережі», щоб школярі ще з початкових класів знали про їх значення та для чого вони потрібні. Але не тільки вчителям це питання потрібно обговорювати з дітьми, також це обов'язок батьків, бо саме вдома вони годинами можуть сидіти в просторах Інтернету. I тому батьки повинні слідкувати за тим, який контент переглядають їхні діти та з ким вони спілкуються в соцмережах.

В молодшому шкільному віці дитина дуже вразлива до зовнішніх впливів. На жаль, в Інтернеті ми можемо зустріти тисячі відео з жорстоким змістом, які знаходяться у відкритому доступі. Цей контент найбільше зацікавлює дітей і згодом для них стає нормальним образити слабшого. Поступово діти стають жорстокими, не усвідомлюють, що своїми діями можуть сильно зачепити почуття, образити гідність іншої людини. Глобальною проблемою в соціальних мережах $є$ можливість залишати коментарі. Це призводить до усвідомлення дітьми безкарності за негативні чи образливі коментарі. 
Також заслуговує на увагу на той фракт, що дитина може бути не тільки автором негативу, але і його жертвою (так званий кібербулінг). До прикладу: в одній з анкет на питання «Які коментарі залишають інші користувачі Інтернету в тебе під постами? Чи є вони образливими для тебе?» дівчинка відповіла: «Одного разу я виклала в «Instagram» відео, де я співаю. Мені почали писати погані коментарі, що дуже образило мене. Тепер я не ходжу на хор, бо мені сказали, що я вию як собака». На жаль, як ми бачимо, звичайний коментар може образити дитину та негативно вплинути на її життя, що на сьогодні цілком реально.

Негативним аспектом соціальних мереж є ризик виникнення залежності від них. Учні вже в початковій школі мають акаунти в більшості популярних мереж і проводять там більшість свого вільного часу. Опитування показало, що більше $50 \%$ учнів проводить в Інтернеті більше ніж 2 години на день (див. рис. 1). Що саме дитина робить і який контент переглядає нам невідомо.

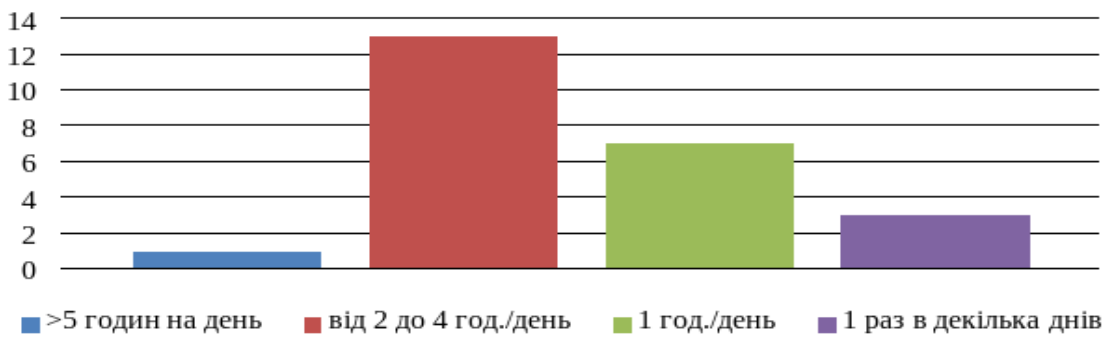

Рис.1. Час, який витрачають діти на соціальні мережі

У 2011 році науковці з Університету Ноттінгем Дарія Кусс та Марк Гріффрітс проаналізували 43 попередніх дослідження в цій галузі і дійшли висновку, що залежність від соціальних мереж дійсно є психічним розладом і він потребує професійної допомоги. Вони виявили зв'язок між надмірним користуванням соціальними мережами що призводить до таких проблем як зміна стосунків з батьками та друзями, погіршенням результатів навчання та малою зацікавленістю в реальному спілкуванні [2].

Ще одним недоліком соціальних мереж $є$ виникнення такого негативного почуття, як заздрість. Діти самі не розуміючи цього порівнюють своє життя з тим яке бачать на яскравих картинках та відеороликах. Заздрість породжує ненависть не тільки до автора посту, а й до свого життя, батьків, друзів та інших користувачів соціальних мереж. Ненависті стає багато і вона з часом знаходить певний вихід. Це може спричинити появу негативних коментарів, жорстокості дитини та постійної роздратованості.

Результати досліджень учених свідчать, що через надмірне перебування в Інтернеті у дитини можуть виникнути порушення сну, стрес, часта зміна настрою, низька самооцінка, погіршення зору, не вміння спілкуватися реальному житті.

Деякі батьки забороняють дітям користуватися соціальними мережами. Цього робити не варто. Адже соціальні мережі мають і позитивний вплив на дитину: допомога у навчанні, перегляд корисних та цікавих, наукових 
відеороликів, слухання музики, спілкування з друзями, які перебувають на відстані та ін. Наприклад, позитивною стороною соціальних мереж $є$ те, що учні класу, створюючи бесіду, можуть швидше вирішити певну проблему (з домашнім завданням, проектами, непорозуміння з друзями тощо). Водночас існує ризик булінгу в школі, коли учні отримують безліч негативних повідомлень в класній бесіді.

Отже, проведене дослідження дозволяє зробити такі висновки: соціальні мережі можуть мати як позитивний, так і негативний вплив на молодшого школяра. Саме тому батьки та вчителі повинні приділяти значну увагу діяльності дитини в Інтернеті, перевіряти контент використовуваний дитиною, зміст постів, розміщені на її сторінці, а також осіб, з якими вона спілкується. Важливо, при виникненні однієї з проблем компетентно підійти до ії вирішення. Ні в якому разі не можна залякувати та карати дитину. У більшості випадків школяр не розуміє всієї серйозності ситуації і просто потрапив під чийсь вплив. Аби уникнути залежності і негативних наслідків користування дитиною соціальними мережами, батькам варто встановити певний ліміт часу, протягом якого дитина може перебувати в соціальних мережах (не більше 1 години на добу). Учитель також відіграє важливу роль в цьому питанні. Він також має проінформувати кожного учня про позитивні та негативні впливи соціальних мереж на фізичне та психологічне здоров'я дитини.

\section{Список використаних джерел:}

1. Джессіка, Браун. (2018). Як соцмережі впливають на наш настрій,сон, психічне здоров'я і стосунки. URL: https://www.bbc.com/ukrainian/vert-fut-42693578 (дата звернення 07.12.2019).

2. Barnes, J. A. Class and Committees in a Norwegian Island Parish by: J. A. Barnes / Human Relations, Vol. 7, No. 1. (1 February 1954), pp. 39-58.

\section{ДЕЯКІ АСПЕКТИ ВИКОРИСТАННЯ ШТУЧНОГО ІНТЕЛЕКТУ В ГАЛУЗІ ОСВІТИ}

Тищенко Микола Андрійович

викладач

Національний технічний університет України «Київський політехнічний інститут імені Ігоря Сікорського»

УКРАЇHA

У двадцять першому столітті людство все частіше стикається з проблемою виконання надважких обчислювальних завдань чи завдань, які можна віднести до рутинних. Кожного дня велика кількість годин робочого часу використовується працівниками для відповідей на одні й ті самі питання. Це призводить до зменшення продуктивності роботи як окремого працівника, так і організації в цілому. Але досвід іноземних компаній помалу приходить і в усі сфери життєдіяльності нашої країни, де все частіше люди використовують 
штучний інтелект у своєму повсякденному житті, навіть не замислюючись про це. Одним з прикладів використання штучного інтелекту є голосові асистенти, які є вбудованими резидентними програмами в мобільні операційні системи, такі як, iOS, Windows Mobile, Android тощо. За допомогою цих прикладних програм користувач може зробити запит на отримання інформації з мережі Інтернет лише активувавши голосовий асистент та промовивши питання. Далі штучний інтелект оброблює запит та надає можливі шаблони виконання потрібного завдання. Іншим прикладом використання штучного інтелекту $є$ застосування фотокамер на сучасних смартфонах, де система сама опрацьовує світлину та корегує ріні рівні освітлення, яскравості та інших параметрів зробленого фото. Але чи можливо використовувати штучний інтелект в галузі освіти? На жаль, це питання не $є$ всебічно розглянутим закордонними та вітчизняними науковцями, що робить його актуальним для подальшого вивчення.

Проаналізувавши публікації вітчизняних та закордонних вчених в галузі методики викладання та інформаційних технологій, ми можемо констатувати підвищення зацікавленості у використанні штучного інтелекту в освітніх цілях через наступні фрактори:

- економія коштів на створення умов для навчання. Поєднуючи інструменти штучного інтелекту та віртуальної реальності, навчальному закладу необхідно мати лише базові інфрормаційно-комунікаційні технології, підтримкою яких може займатись невеликий штат технічних працівників;

- відсутність страху у студента через невиконання завдання. Чудовим прикладом переваги використання штучного інтелекту на практичних заняттях може бути віртуальне середовище тренування автопілотів департаменту оборони Сполучених Штатів Америки, де студенти тренуються на авіосимуляторах та не бояться завдати шкоди власному здоров'ю чи зламати дороге обладнання;

- мотивація прискорювати процес навчання. Вже сьогодні штучний інтелект може бути запрограмований таким чином, що студент не може перейти до наступного модулю, не виконавши попередній. Усі помилки, зроблені студентом під час виконання практичної роботи, вираховуються силами штучного інтелекту, який власноруч розробляє найбільш сприятливі сценарії подальшого навчання студента.

Говорячи про переваги використання штучного інтелекту в галузі освіти потрібно розуміти й можливі недоліки, з якими можуть стикнутись освітяни, а саме:

- необхідність у спеціальному навчанні викладачів коректної роботи 3 системами штучного інтелекту;

- значні економічні затрати, які потрібно зробити на придбання спеціального обладнання та на оплату заробітної платні відділу підтримки систем штучного інтелекту;

- мотивація співробітників імплементувати новітні технології навчання в уже злагоджене освітнє середовище.

Підводячи підсумки розгляду деяких аспектів використання штучного інтелекту в галузі освіти, слід зазначити, що, на нашу думку, для найбільш плідної реалізації такого підходу потрібно спершу побудувати міцну основу 3 
підготовки викладачів. Саме викладачі можуть зіграти основну роль в цій ідеї, оскільки вони можуть корегувати роботу програмістів, пояснюючи методичні аспекти навчання студентів, а також власною ініціативною працею освітяни можуть наповнити платформу змістовною складовою знань.

\section{Список використаних джерел:}

1. Bundy, A., \& Burstall, R. (2014). Artificial Intelligence: An Introductory Course (2nd ed.). Edinburgh, UK: Edinburgh University Press. (Original work published 1999).

2. Nilsson, N. J. (2019). The Quest for Artificial Intelligence. Cambridge, UK: Cambridge University Press.

3. Russell, S. J., \& Norvig, P. (2015). Artificial Intelligence: A Modern Approach (3rd ed.). London, UK: Pearson.

DOI 10.36074/13.12.2019.v3.05

\section{ІНТЕРАКТИВНІ ТЕХНОЛОГІЇ КОЛЕКТИВНО-ГРУПОВОГО НАВЧАННЯ ЯК ЗАСІБ ТВОРЧОГО РОЗВИТКУ молодших школяРІВ}

\section{Бондар Юлія Володимирівна}

аспірантка

Тернопільський національний педагогічний університет імені Володимира Гнатюка

НАУКОВИЙ КЕРІВНИК:

Сорока Ольга Вікторівна доктор педагогічних наук, професор кафедри соціальної педагогіки і соціальної роботи

Тернопільський національний педагогічний університет імені Володимира Гнатюка

УКРӒ̈HA

Пошук новітніх підходів до організації освітнього процесу в закладах загальної середньої освіти $€$ вимогою часу, адже сучасний інформаційний розвиток суспільства потребує творчих, ініціативних, винахідливих особистостей, які здатні нестандартно мислити, генерувати оригінальні ідеї, знаходити шляхи вирішення у різних ситуаціях. Тому необхідна така організація навчально-виховного процесу, яка б сприяла фрормуванню творчих умінь молодших школярів та розвитку їхніх здібностей. Одним із найперспективніших шляхів розвитку творчості у дітей $є$ впровадження у навчально-виховний процес початкової школи інтерактивних технологій, оскільки вони володіють потужним інноваційним потенціалом, дають змогу створити комфортні умови навчання, за яких кожен учень відчуватиме свою успішність та інтелектуальну спроможність. Вважаємо, що застосування технологій колективно-групового навчання допоможе налагодженню партнерської взаємодії у системах «учень-учні» та «учень-учитель», тим самим перетворивши школярів на активних суб'єктів навчальної діяльності. 
Мета дослідження - розкрити особливості використання інтерактивних технологій колективно-групового навчання в початковій школі як засобу творчого розвитку молодшого школярів.

Дослідженням проблеми організації групової діяльності займалися психологи (В. Бехтєрєв, П. Блонський, М. Ланге), педагоги-новатори (Є. Ільїн, С. Лисенкова, В. Шаталов). На пріоритетність колективно-групових технологій в системі педагогічних інновацій наголошували Т. Дуткевич, М. Кларін, Л. Пироженко, О. Пометун, І. Якиманська та інші.

Технології колективно-групового навчання, на переконання О. Пометун, це інтерактивні технології, що передбачають одночасну фронтальну роботу всього класу. До даної групи інтерактивних технологій, залежно від мети уроку та форм організації навчальної діяльності учнів, дослідниця відносить такі, як «Мікрофон», «Незакінчені пропозиції», «Мозковий штурм», «Навчаючи вчуся», «Обговорення проблем у загальному колі», «Ажурна пилка» («Мозаїка» або «Джиг-со»), «Кейс метод», «Аналіз ситуації» (case-study), «Дерево рішень», «Вирішення проблем», «Кожен навчає кожного» або «Броунівський рух» [1].

Розглянемо деякі 3 них детальніше. Технологія загальногрупового обговорення «Мікрофон» надає можливість швидко висловлювати свою думку, або позицію з тієї чи іншої проблеми. Організація роботи передбачає такі етапи: постановку вчителем запитання класу; передачу уявного мікрофону; швидкі та лаконічні відповіді (0,5-1 хв.), які не обговорюються і не оцінюються. Перевагами даної технології $\epsilon$ те, що учнів не потрібно об'єднувати у групи, діти можуть фантазувати, придумуючи оригінальні відповіді. Використовувати технологію «Мікрофон» можна на усіх уроках в початковій школі, наприклад, на уроках математики для закріплення складу числа, таблиць додавання, одиниць вимірювань величин [2].

Ще однією цікавою інтерактивною технологією $є$ «Незакінчені пропозиції», яка дає можливість вільно, коротко та переконливо висловлюватись на запропоновану тему. Учитель формулює початок речення і пропонує учням продовжити його. Зокрема, на уроках української мови вчитель може запропонувати завдання, які сприяють розвитку творчих здібностей, наприклад, придумати закінчення речення «Я більше не буду...» (про дбайливе ставлення до природи). Продовжити фразеологізми: «твердий як...», «сильний як...», «повільний як...», «солодкий як...», «хитрий як...». Доречною буде вправа «Назви ціле за його частинами». Наприклад, «обкладинка, сторінка, корінець - це... (фотоальбом, книга)», «дерева, кущі, трава, ягоди, гриби - це ... (ліс)». Також дану технологію радимо використовувати на етапі підведення підсумків уроку, пропонуючи речення відкритого типу: "Сьогодні мене найбільше вразило...», «На уроці мені найбільше сподобалося...», «Аналізуючи дану проблему, ми прийшли до висновку, що...» [1].

Відомою колективно-груповою технологією, яка дає змогу учням вільно висловлювати свої думки, проявляти креативність, $€$ метод «Мозковий штурм». Учитель записує на дошці проблемне запитання, яке мають обговорити учні всього класу. Запропоновані ідеї фріксуються, після чого відбувається їхній аналіз, групування й обираються лише ті, що необхідні для 
вирішення завдання. Мета технології - зібрати якомога більше цікавих ідей для розв'язання конкретної проблеми за обмежений проміжок часу. На інтегрованому уроці «Я досліджую світ» можна обговорити 3 дітьми такі запитання проблемного характеру: «Чому рослини в лісах ростуть ярусами?», «Навіщо рослини «об'єднуються» в ліс?», «Чим відрізняється озеро від моря?», «Навіщо люди живуть селами і будують міста?» тощо. Означена технологія сприяє розвитку динамічності розумових процесів, здатності концентрувати увагу на суттєвій проблемі та абстрагуватися від будь-яких обмежень [2].

Ще однією ефективною технологією, яка дає змогу учням за короткий час засвоїти великий обсяг інформації $\epsilon$ технологія «Ажурна пилка». Клас поділяється на дві групи - «домашня» та «експертна». Кожен учень входить у кожну з цих груп. «Домашні групи» мають проаналізувати та засвоїти інформацію з метою подальшого обговорення. До «експертних» груп входить один представник з кожної «домашньої» групи. Отримавши інформацію в «експертній» групі, учні повертають до «домашньої» групи і обговорюють її. Технологія заохочує учнів, навчаючи інших, активно навчатись самим [3].

Л. Акпинар наголошує, що під час організації інтерактивної колективногрупової взаємодії головним завданням вчителя виступає активізація учнів під час пошуку шляхів розв'язання навчальної проблеми. Велика кількість наданих пропозицій щодо вирішення проблеми у підсумку сприятиме її ефективному розв'язанню [4].

Важливими для нашого дослідження є погляди Л. Баленко, яка вказує на переваги використання інтерактивних технологій колективно-групового навчання в освітньому процесі, оскільки вони:

- мотивують та активізують учнів до навчальної діяльності;

- розвивають та розширюють комунікативні навички, зокрема, сприяють формуванню здатності чітко і переконливо висловлювати і доводити свою думку, бути небагатослівним і зрозумілим;

- забезпечують оперативний зворотній зв'язок;

- сприяють розвитку творчої уяви, мислення, франтазії [5].

Отже, інтерактивне навчання $є$ цікавим, творчим, інноваційним напрямом модернізації сучасної системи початкової освіти. Завдяки застосуванню інтерактивних технологій колективно-групового навчання діти зможуть успішно засвоїти навчальний матеріал, проявивши при цьому творчість.

\section{Список використаних джерел:}

1. Пометун, О. І., Пироженко, Л. В. (2005). Сучасний урок: інтерактивні технології навчання. Київ: А.С.К.

2. Каленюк, Л. В. (2010). Інтерактивні технології - перспектива розвитку використання інтерактивних технологій в навчальному процесі. Розкажіть онуку, (5), 8-30.

3. Бурлаєва, Л. Ф. (2005). Інтерактивні технології в таблицях. Управління школою, (16-18), 4955.

4. Акпинар, Л. Е. (2014). Інтерактивні технології навчання в початковій школі. Київ: Слово.

5. Баленко, Л.М. (2010). Інноваційні педагогічні технології в навчальному процесі. Завучу. Усе для роботи, (20), 13-17. 


\section{НЕПЕРЕРВНА ПЕДАГОГІЧНА ОСВІТА ЯК ФІЛОСОФСЬКА КАТЕГОРІЯ}

\section{Ходунова Вікторія Леонідівна \\ канд. пед. наук, доцент, докторант аціональний педагогічний університет імені М.П.Драгоманова}

УКРӒ̈̈А

Актуальність проблеми неперервної педагогічної освіти дорослих зумовлюється низкою соціальних, економічних та культурних тенденцій сучасного суспільства. В умовах глобалізаційних процесів взаємопроникнення ринків праці та інтернаціоналізації національних економік, пов'язаною з цим інтенсивною міграцією робочої сили, неперервний професійний розвиток фахівців на особистісному рівні розглядається як одна з найголовніших умов індивідуального успіху, а на рівні суспільства - це рушійна сила науковотехнічного прогресу, ефективний засіб боротьби з безробіттям, а також потужний фактор, що забезпечує економічне процвітання фрірм і компаній.

Як зазначено у Національній доктрині розвитку освіти в Україні у XXI столітті, Законі України «Про освіту» (2017), Концепції реалізації державноі політики у сфері реформування загальної середньої освіти «Нова українська школа» на період до 2029 року, реалії сьогодення вимагають самореалізації кожної особистості, фрормування від педагога високого рівня професіоналізму, творчої соціально-професійної активності та здатності навчатися впродовж усього життя, «перетворення набуття освіти у процес, який триває упродовж усього життя людини» [1].

3'ясуємо концептуальні підходи до розуміння сутності проблеми нашого дослідження, серед яких найбільш значущим $є$ філософсько-педагогічна ідея неперервності освіти (В. Андрущенко, І. Зязюн, В. Краєвський, В. Кремень, В. Молодиченко, О. Новіков, Т. Троїцька та ін.). Проведений аналіз різних філософських напрямів дав нам змогу проаналізувати діалектику неперервної освіти, дослідити різні аспекти функціонування системи освіти дорослих, виявити її зв'язок із соціумом, культурою, ідеалами та цінностями суспільства, а також обґрунтувати тенденції її розвитку.

3 погляду філософії, неперервна освіта $€$ трансформацією у структуру свідомості, світогляд, духовний світ і культуру особистості. Звертаючись до трактування І. Зязюном неперервної освіти, як складного явища, відзначимо розуміння науковцем глибини цієі фрілософсько-педагогічної ідеї: "Це, передусім, усвідомлення освіти як процесу, що охоплює все життя; це невпинне цілеспрямоване засвоєння людиною соціокультурного досвіду 3 використанням усіх ланок існуючої освітньої системи; це - дотримання означеного принципу організації освіти, освітньої політики, спрямованої на створення умов для навчання людини впродовж усього іїжиття, забезпечення взаємозв“язку і спадковості різних ланок освіти" [2]. Саме через неперервну освіту визначаються суспільно вагомі параметри особистості. Філософрія ж освіти корегує, по-перше, його суспільну якість і значення; по-друге, 
ефективність реалізації педагогічними заходами в умовах і можливостях наявного типу культури; по-третє, відповідність загально цивілізаційним магістралям розвитку людства у загальноісторичному аспекті.

Становлення сучасного фрілософсько-освітнього дискурсу стосовно походження ідеї неперервної освіти відбувається під впливом різних провідних тенденцій. Одна із них заснована на стародавньому походженні неперервної освіти, що розгорталась, починаючи з античного світу. ІЇ̈ джерелом є релігійнофрілософські уявлення і вчення про постійне духовне вдосконалення людини (Г. Зінченко, Л. Владіславлев, Х. Гуммель, А.Даринський, Г. Ягодін) [3].

Прихильники іншої тенденції пов'язують появу ідеї неперервної освіти із сучасною епохою, яка характеризується активними процесами розвитку в духовній, соціальній, виробничій і науково-технічній сферах (В. Осипов, О.Купцов та ін.). За їх ствердженням, сам факт ідеї неперервної освіти має безпосереднє відношення до фундаментальних для розвитку сучасної цивілізації процесів, пов'язаних з якісними змінами соціальної ролі освіти.

Проміжна точка зору стосується ідеї концептуального втілення неперервної освіти лише в епоху науково-технічної революції (В. Аношкіна, С. Резванов та iн.).

На противагу цим дослідженням інша група вчених наполягає, що хоча сама ідея неперервної освіти існує в педагогіці досить давно, аде відповідний вид практики виник недавно (О. Владиславлєв, Г. Зінченко, В. Онушкін). Особливо значущими здобутками концепції неперервності освіти $€$ роботи Демокрита, Платона, Конфуція, Сократа, Аристотеля, Сенеки. Філософами було визначено завдання неперервної освіти: панування загального блага«спільність радості і горя»; відвернення людини від вузько суб'єктивних інтересів; аристократизм, духовність та внутрішня моральність. Згідно з ідеями Арістіпа, Анаксагора, Євгемера, Теофаста сенс неперервної освіти знаходиться у вихованні визначальних рис характеру особистості. Освіта, за їх ствердженням - єдине, що піднімає людство на нові щаблі розвитку науки та культури [3].

Представники просвітництва одностайні у поглядах на неперервну освіту як особливу форму освіти дорослих, що є їі суттєвим системо- утворювальним елементом, який безпосередньо пов'язаний з неформальною освітою дорослих. Через просвітництво, - вважає Л. Золнер, - досягається інтерпретація життєвих проблем та «розуміння» життя. Це більше ніж надання інформації або передавання знань, оскільки просвітництво передбачає не тільки набуття знань (інтелектуальний аспект), а й активну участь кожного в цьому процесі (емоційнй аспект). Просвітництво дає кожному віру в те, що він чи вона здатні діяти, брати відповідальність у вирішенні проблем [4].

Витоки ідеї освіти впродовж життя можна знайти в поглядах Вольтера, И. В. Гете, Ж. Ж. Руссо, які безпосередньо пов'язували її з досягненням вершини розвитку людства. За їх ствердженням, саме неперервна освіта, сприяє формуванню гармонійної, всебічно розвиненої, самодостатньої особистості, з розвиненими почуттями і волею, здатністю орієнтуватися у глобальних інформаційних потоках, жити і працювати у світі постійних змін і трансформацій. 
Попередниками сучасних уявлень про неперервну освіту вважаються фрілософські і педагогічні ідеї, які були сформульовані Я. А. Коменським, Й.Г. Песталлоці, Й. Гербартом, А. Дістервегом. Саме в їх теорії простежуються витоки популярності неперервної освіти через здобуття нових знань, розвиток природних здібностей кожного. Саме в цей час відбувається "розчаклування світу", а світ стає прозорим і зрозумілим для того, хто пізнає раціонально. Якщо людина ще чогось не знає, вона обов'язково колись зможе про це дізнатись, якщо не буде відмовлятися від раціонального способу опанування світом [5].

Усвідомлення теоретичного й практичного значення неперервної освіти відбулося за результатами науково-практичних досліджень, висвітлених у працях Р.Х. Дейва, А. Делеона, Д. Р. Кідда, П. Ленграна, Є.Фора, Ф. Єддінга та iн. Було доведено, що неперервне навчання дорослих ґрунтується на культивуванні особистості, ії прав та свободи інтелекту, оволодінні фактичними знаннями, систематичному навчанні та формуванні навичок аналітичного мислення. Неперервна освіта базується на інтеграції освітніх дискретних ресурсів суспільства, акумульованих у традиційних інституціональних формах навчання і просвіти людей з метою сприяння соціальній адаптації особистості, перманентного підвищення культури особистості з метою підвищення якості життя. Мало місце надання освітніх можливостей тим, хто хоче навчатися; задоволення потреб спільноти; задоволення потреб окремих груп населення (мається на увазі професійна підготовка); вільна освіта (виховання вільної людини).

Набули актуальності фундаментальні узагальнюючі концепції до інтерпретації суті неперервної освіти: неогуманізм (ідея «Folkbuilding», націоналізація непрофесійної народної освіти - Н. Ф. С. Грундтвиг, В. Ленц, Ф. Пеггелер); лібералізм (доступність та неперервність освіти, підвищення її стандартів - Н. Батлер, К. Гоул, И. Елає, Дж. Ньюмен, Дж. Рассел); прагматизм (освіта $\epsilon$ головним засобом соціальних змін і розвитку суспільства- М. Берубе, Т. Брамельд, Дж. Дьюї, В. Джеймс, Е. Ліндеман, Ф. Ньюмен, Ч. Пірс, Г. Шейн, Д. Фішер); біхевіоризм (освіта дорослих виступає механізмом змін поведінки та активності дорослої особи - Д. Зиглер, А. Х'єлл); технократизм (використання досягнень науково-технічного прогресу у підготовці компетентних працівників із значним обсягом інтелектуальних умінь та навичок - 3. Бжезинський («технотронне суспільство»), Д. Бел («постіндустріальне суспільство»), Дж. Гелбрейт («нове індустріальне суспільство»), П. Друкер («наукове суспільство»); радикалізм (диверсифікація шляхів освіти через створення своєрідної мережі з обміну знань - П. Фрейре, І. Ілліч, Дж. Мезіроу, Дж. Холт, Г. Жиру, П. Макларен та ін); конструктивізм (діяльнісний підхід із опорою на розвивальні концепції і технології; проектування змісту та методів навчання у відповідності до потреб тих, хто навчається; створення умов для реалізації індивідуального підходуК. Адельман, Дж. Дьюї, Дж. Мезіроу, С. Брукфілд та Ю. Габермас, Ж. Піаже, А. Шюц); гуманізм (доросла людина $є$ активним суб‘єктом непланованого навчального процесу, що сприяє ії розвитку та удосконаленню на різних етапах ії життєдіяльності - А. Маслоу, М. Ноулз, К. Роджерс); «освіти для виживання» (survival education) (головна мета освіти полягає у навчанні виживати в умовах конфліктів і колізій- Р. Амара, Дж. Джоунс, Д. Кауфрман, Д. Манн, Ф. Ньюмен, 
М. Скрівен; громадська освіта (community education) - Э. Гуссерль, А. Нокс, Д. Колб, Р. Фрай, П. Джарвис, Д. Шон, та ін.; принципи організації дорослих - М. Ноулз; здатність навчатися у будь-якому віці -К. Шаиее, С. Уілліс; стадії когнітивного розвитку - М. Комменс, Ф. Річардс, К. Армон; моделі навчання дорослих - В. Перрі, М. Беленкі, Б. Клінш, Н. Голдбергер, Дж. Тарул).

Поза тим, ряд досліджень свідчить про зв'язок неперервної освіти з політичною, економічною та суспільною системою країни. Цей фракт підтверджує головну тезу теорії У. Гартеншлегера, що «навчання впродовж життя може стати інструментом, який допоможе нам сформувати відношення між $Є С$ і сусідніми країнами в конструктивному і плідному руслі, заснованому на тотожному сприйнятті європейських цінностей, а не тільки на певних угодах між урядами» [6].

Нова освітня парадигма спонукає по-новому усвідомлювати проблему неперервної освіти, яка базується на послідовному взаємозв'язку всіх ланок освіти: дошкільна - початкова - середня професійна - вища - освіта після закінчення закладу вищої освіти - підвищення кваліфрікації. Очевидно, що кожна з них має особливі цілі та функції, адекватні до соціального становища людини. Реалізація освітнього ланцюжка уможливлює відкритість, гнучкість системи освіти, інноваційність змісту, засобів і методик навчання, можливість вільного їх вибору. При цьому, П. Альхайт акцентує на різноманітності форм неперервної освіти - неформальної, що відбувається в освітніх закладах або громадських організаціях, поза формальною системою, та інформальної, що спрямована на набуття додаткових, необхідних особі знань, умінь, компетенцій, результат такого навчання формально не визнається. Поняття неформальної освіти дорослих частково збігається з такими поняттями, як «додаткова» і «продовжена» освіта. Саме неформальна освіта, з одного боку, задовольняє запити особистості, забезпечує умови для її самореаізації, морального вдосконалення за рахунок надання широких можливостей у виборі напряму й форм освітньої діяльності, з іншого боку, є дієвим механізмом фрормування соціально активних громадян, мобільних як у професійному, так й особистісному контекстах до швидкоплинних змін соціального середовища.

Висновок. Виходячи із різних фрілософрсько-педагогічних концепцій неперервна освіта переважно розглядається як процес, що здіиснюється впродовж усього життя, завдання якого полягають у створенні умов для задоволення освітніх потреб громадян, їх можливостей для професійного розвитку та самореалізації, підвищення ефективності йрезультативності їхньої життєдіяльності. Усі дослідники акцентують увагу на провідних тенденціях неперервної освіти: цілеспрямованість освітнього процесу в інтересах людини, суспільства і держави, інноваційність, урізноманітнення змісту, форм і методів, трансформація й оновлення усталених структур.

\section{Список використаних джерел:}

1. Міністерство освіти і науки України - нова українська школа. mon.gov.ua (ua). Процитовано 2019-12-04.

2. Зязюн І.А. (ред.) (2000)Неперервна професійна освіта: проблеми, пошуки, перспективи Київ: Віпол.

3. Кремень В. Г., Ільїн В. В. (2005). Філософія: мислителі, ідеї, концепці. Київ: Книга. 
4. Zøllner L. (2000)Education and Enlightenment (p. 55). Odense: University of Southern Denmark.

5. Вебер M (1998) Соціологія. Загальноісторичні аналізи. Політика. Київ: Основи.

6. У. Гартеншлегер (2010). Европейское образование взрослых за пределами ЕС (О. Вербова, пер. с англ.). Київ: Энергия.

7. Alheit P. Dausien B. (2002). Bildungsprozesse über die Lebenspanne und lebenlanges Lernen (pp. 569-589). Handbuch Bildungforschung. Opladen.

\title{
ОБУЧЕНИЕ ЧТЕНИЮ ИНОСТРАННЫХ УЧАЩИХСЯ В СИСТЕМЕ РКИ НА НАЧАЛЬНОМ И ПРОДВИНУТОМ ЭТАПАХ
}

\author{
ст. преп. кафедры языковой подготовки 1 \\ Учебно-научный институт международного образования \\ Харьковский национальный университет им. В. Н. Каразина
}

Черненко Ирина Ивановна

УКРАИНА

Обучение чтению является одной из важнейших задач в программе обучения русскому языку как иностранному и рассматривается как один из видов речевой деятельности (наряду с обучением письму, говорению, аудированию). «Давно замечено, что чтение оказывает благотворное влияние на развитие других видов речевой деятельности... Считается, что степень владения иностранным языком находится в прямой зависимости от количества прочитанных страниц текста на этом языке. Кроме увеличения языкового потенциала чтение способствует также активному запоминанию лексики и грамматических конструкций» [3].

Акцентирование внимания на этом аспекте обусловлено, с одной стороны, особой значимостью его, а с другой стороны, неутешительной картиной стартового контроля иностранных студентов, поступающих на первый курс (скорость чтения варьируется от 25 слов/мин. до 65 слов/мин. при норме скорости чтения (изучающее чтение) во втором семестре на подготовительном факультете - 60-75 слов/мин.; скорость чтения (изучающее чтение при полноте восприятия до 90\%) - 40-50 сл/мин. Комментируя эти результаты, можно говорить о нескольких вариантах сформированности навыков чтения: 1) слабая техника чтения и непонимание прочитанного; 2) техника чтения на среднем уровне, но затруднения при контроле понимания; 3) хороший темп чтения и понимания текстов нейтрального стиля, но трудности при чтении и восприятии текстов научного характера; 4) достаточно быстрое правильное чтение и хорошее понимание текстов различного стиля (художественного, научного, публицистического). К сожалению, последняя группа представлена единичными студентами.

Мы начали с анализа техники чтения не потому, что ставим ее на первое место, а потому, что без этого невозможно понимание прочитанного. Понимание читаемого - сложный мыслительный процесс, обусловленный не только расшифровкой содержащейся в тексте информации, но и использованием предыдущего опыта и знаний в этой области. Понимание 
текста на иностранном языке затрудняется тем, что читающий должен фиксировать внимание не только на содержательной стороне, но и на способах языкового оформлении текста.

Выработка основных навыков техники чтения (т.е. правильного произношения слов, словосочетаний, предложений, интонирование) происходит на начальном этапе изучения языка. В первое время внимание студента нередко приковано к технике чтения, они поглощены процессом, а связи между словами, значение отдельных слов и словосочетаний, содержание текста не улавливается. Безусловно, поначалу необходимо, чтобы преподаватель корректировал чтение студента, исправлял его ошибки по ходу чтения, но важно, чтобы этот процесс не затянулся и у студента не сформировался комплекс.

Преподаватель должен стремиться отвлечь от трудностей процесса чтения, переключить на понимание содержания (с помощью предварительной беседы по содержанию, картинок, предтекстовых упражнений, подчеркивания ключевых слов, задания быстро найти ответ на вопрос и др.), а ошибки при чтении фиксировать и анализировать после чтения, включать в фонетические упражнения. Классическая схема обучения чтению на начальном этапе предполагает прослушивание текста в записи, затем чтение преподавателем как образец, после этого чтение сильными студентами по абзацам, при этом проверяя понимание прочитанного. На более поздних этапах обучения студенты читают текст самостоятельно вслух или «про себя», на основных факультетах последний вид чтения предпочтительнее. На начальном этапе, как правило, преобладает аналитическое чтение, на основных факультетах (в частности, на первом курсе) рекомендуется синтетическое чтение. «Задача синтетического чтения - охватить целое, понять текст без предварительного анализа лексики, грамматических форм, без посредства перевода на родной язык» [2]. Такое чтение можно практиковать постепенно и на подготовительном факультете, поначалу тщательно подготавливая с помощью определенных упражнений, разъяснения названия текста, некоторых слов или словосочетаний, важных для понимания, правильного использования словаря. В качестве поддержки полезной будет информация о том, что теоретически и экспериментально подтверждено, что «человек может понять общую идею текста, если в нем есть до ...30\% незнакомых слов, присутствие же 10\% незнакомой лексики вообще не влияет на понимание общего содержания» [2].

Подготовка к чтению и собственно чтение - первые этапы работы с текстом. Очень важный этап в обучении чтению - проверка понимания прочитанного. Самый распространенный способ - это ответы на вопросы после текста; следующий шаг - деление текста на части, составление плана, наконец, это может быть пересказ прочитанного (по плану, по опорным словам). Однако можно предложить и такие виды заданий: выбрать из текста предложения, соответствующие по смыслу записанным на доске; выбрать из нескольких вариантов соответствующее содержанию текста; оценить правильность того или иного высказывания, опираясь на содержание текста; найти высказывание, раскрывающее какую-либо ситуацию, подтверждающее или опровергающее предложенный тезис; составить вопросы к тексту. В любом тексте можно выделить главную информацию (основные мысли, положения, факты), второстепенную (аргументация, пояснения), есть еще 
иллюстрации, схемы, сравнения. Очень важно научить студентов ориентироваться в этом, самостоятельно разбираться «в смысловой иерархии текста», запоминать важную информацию, а не заучивать бездумно. Некоторые методисты предлагают использовать разные цвета для выделения главной, второстепенной, иллюстрирующей информации. Выполнив задание, студенты, доказывают правильность своей «сортировки» [3]. Разумеется, существуют и другие виды проверки понимания прочитанного, каждый из видов целесообразно использовать на различном по трудности материале.

Безусловно, навыки синтетического чтения невозможно сформировать, ограничиваясь только аудиторным чтением, необходимо уделять серьезное внимании систематическому интенсивному чтению посильной дополнительной литературы (домашнее, внеаудиторное чтение). Именно в процессе этой деятельности развивается техника чтения, а также закрепляются изученная лексика и грамматика и пополняется словарный запас учащихся. При этом очень важно правильно подобрать тексты для домашнего чтения с точки зрения объема (они не должны быть слишком большие), степени трудности (не очень легкие, но посильные), содержания (интересные, познавательные), жанра (тексты художественной литературы, пьесы; содержательные отрывки, требующие осмысления). Разумеется, домашнее чтение должно контролироваться, тем более что это хороший материал для перехода от учебной коммуникации к естественному общению.

Обучая чтению, следует особо остановиться на работе со словарем. Этому нужно учить студентов-иностранцев с первых дней обучения. Отличное знание алфавита, знание особенностей словаря, навык ориентировки в структуре словарной статьи - первые условия быстрой и успешной работы со словарем. У студентов нужно вырабатывать установку, что первое чтение текста для понимания общего смысл - без словаря, что к словарю нужно обращаться лишь тогда, когда непонятен смыл прочитанного при незнании часто повторяющегося слова, что о значении некоторых слов можно догадаться или уточнить его значение по словарю при повторном чтении. Можно наблюдать такую картину: читая текст, студент выписывает непонятные ему слова (целая простыня), потом выписывает к ним из словаря значения, зачастую не то, которое необходимо (особенно в случае с многозначными словами). Поэтому необходимо практиковать упражнения по определению студентами словарной формы встретившегося в тексте слова, формировать потенциальный словарь с помощью упражнений на словообразование, синонимию, установление родственных слов и т.д.

Для беспереводного чтения важно формировать навыки прогнозирования. Интуитивно мы стремимся и в устной речи предугадать следующие слова собеседника, и в чтении ранее прочитанное подсказывает, о чем буде речь дальше. «В процессе чтения читающий как бы постоянно забегает вперед. Пытаясь предугадать, предвосхитить гипотезы о дальнейшем изложении. Этот механизм, который называется вероятностным прогнозированием, может проявляться на двух уровнях: 1) вербальное прогнозирование (по нескольким буквам угадывается слово, по первому слову - словосочетание, по первым словам - все предложение) и 2) смысловое прогнозирование (построение гипотез о дальнейших фактах, событиях). Смысловое прогнозирование строится уже на воспринятых фрактах текста и на имеющемся жизненном опыте. Вербальное прогнозирование, которое опирается на 
языковой опыт учащегося, должно быть в центре внимания преподавателя на всех этапах обучения чтению» [3]. На развитие этого умения должны быть направлена систематическая работа: упражнения на восстановление пропущенного слова в словосочетаниях, предложениях; на использование в предложениях разных, но подходящих по смыслу слов; на конструирование предложений из заданных слов и др. Такие упражнения не только развивают языковую догадку, формируют потенциальный словарь, но и психологически снимают страх перед незнакомым словом, перед новым текстом. Эти упражнения можно осуществлять с помощью карточек или в других вариантах, в том числе и компьютерном.

Что касается конкретных видов чтения, то на начальном этапе и на первом курсе по программе изучающее чтение считается ведущим видом чтения, но не единственным, уже на подготовительном факультете «предлагается формулировать часть заданий с опорой не только на изучающий, но и на ознакомительный (Расставьте пункты плана в логической последовательности), просмотровый (Определите, о чем говорится в тексте), поисковый (Найдите в тексте определение ...) виды чтения» [4]. На продвинутом этапе обучения усложняется характер последующего воспроизведения текстов при изучающем чтении: от выделения основных положений текста и его подробного воспроизведения на основе смысловых и визуальных опор до выхода в монолог-повествование с элементами рассуждения на основе прочитанных текстов. Кроме того, в большей степени представлены другие виды чтения: ознакомительное, просмотровое, поисковое. По одной теме предлагается несколько текстов, в том числе и для самостоятельного чтения, и в ходе работы с этими текстами студенту необходимо выбрать нужную информацию, сравнить, дать оценку, объединить в монологическое высказывание. Задания, характерные для разных видов чтения положены и в основу тестов, предназначенных для проверки текстов по специальности.

В заключение хочется еще раз отметить важность данной проблемы при преподавания русского языка как иностранного, необходимость методического и методологического обоснования работы преподавателя по обучению чтению иностранных учащихся, поскольку обучение чтению непростой последовательный целенаправленный процесс.

\section{Список используемых источников:}

1. Пиневич Е.В. (2011) Обучение чтению иностранных учащихся. Москва: МГТУ им. Н. Э. Баумана.

2. Костомаров В. Г. \& Митрофанова О. Д. (1984) Методическое руководство для преподавателей русского языка иностранцам. Москва: Русский язык.

3. Щукин А. Н. (2003) Методика преподавания русского языка как иностранного: учебное пособие. Москва: Высшая школа.

4. Дзюба Е. В. \& Еремина С. А. (2018) Урок чтения на русском языке в иностранной аудитории: методический и методологический аспекты. Филологический класс, (2), 109-117. 


\title{
ПЕРЕВЕРНУТЕ НАВЧАННЯ ЯК ЗАСІБ ФОРМУВАННЯ ІНФОРМАЦІЙНО-КОМУНІКАЦІЙНОЇ КОМПЕТЕНТНОСТІ СТУДЕНТІВ КОЛЕДЖІВ
}

\author{
Пальчик Олександр Олександрович \\ здобувач вищої освіти (магістрант), кафедри менеджменту \\ освіти та педагогіки вищої школи \\ Сумський державний педагогічний університет імені А. С. Макаренка \\ УКРАЇНA
}

Інформаційні технології - це узагальнююче поняття, що описує різні методи, способи та алгоритми збирання, зберігання, оброблення, представлення і передавання інформації. Під інформаційними технологіями розуміють також способи і засоби збирання, оброблення та передавання інформації з метою одержання нових відомостей про об'єкт, що вивчається, або - сукупність знань про способи і засоби роботи з інформаційними ресурсами [3].

Будь-яка педагогічна технологія - це інформаційна технологія, оскільки основу технологічного процесу навчання складає отримання і перетворення інформації [2].

Перевернуте навчання [1] - одна з форм змішаного навчання, при якій в якості домашнього завдання студенти самостійно вивчають теоретичний матеріал, а увесь час аудиторного заняття у супроводі викладача відводиться для застосування отриманих знань, спільного використання практичних завдань. Така модель заняття припускає створення оптимальних умов для пізнавальної активності студентів, організацію їх такій продуктивній діяльності в рамках теми, що вивчається, при якій вони стають не пасивними споживачами готової інформації, а її здобувачами і переробниками. Як наслідок, перевернуте навчання сприяє [1]:

- Підвищенню навчальної активності студентів, їх мотивації до навчання і захопленості освітньою діяльністю на занятті;

- Реалізація можливості диференційованого підходу в навчанні, роботи в індивідуальному комфортному темпі;

- Підвищенню самостійності студентів, їх відповідальності за навчання;

- Посиланню акценту на практичну продуктивну і творчу діяльність;

- Використанню різноманітних джерел отримання інформації;

- Реформуванню навичок групової, командної роботи;

- Позитивній зміні позиції викладача в освітньому процесі: студенти відчувають потребу у викладачі-консультантові, тренерові, партнерові.

Технологія «перевернутого» навчання $€$ досить новим явищем в освіті, проте зумовлює значний інтерес серед науковців, зокрема закордонних, i відображена у працях таких учених, як Бейкер C. (Baker Celia), Бергманн Дж. (Bergmann J.), Самс А., Беррет Д., Дрісколл Т. та інші [1].

У практиці закордонних педагогів зустрічаються такі види «перевернутих класів» [4]:

- Типовий перевернутий клас (The Standard Inverted Classroom).

- Орієнтований на дискусію перевернутий клас (The Discussion-Oriented Flipped Classroom). 
- Сфокусований на демонстрації перевернутий клас (The DemonstrationFocused Flipped Classroom).

- Псевдоперевернутий клас (The Faux-Flipped Classroom).

- Груповий перевернутий клас (The Group-Based Flipped Classroom).

- Віртуальний перевернутий клас (The Virtual Flipped Classroom).

- «Перевернутий» вчитель (Flipping The Teacher).

На етапі впровадження технології «Перевернуте навчання» в освітній процес (на заняттях фрізики та основ біологічної фрізики), виникало багато питань, тому було прийнято рішення - випробувати кожен з існуючих видів «перевернутого класу». Випробувавши, стало зрозумілим, що ні один з них не задовольняють потреби коледжу, але поєднання елементів кожного може дати потрібний нам результат.

Для початку, було згруповано навчальний матеріал так, щоб кожне лекційне заняття містило приблизно однакову кількість теоретичного матеріалу. Далі було визначено види завдань, які будуть виконуватися на лекційних і практичних заняттях. Наступним етапом стало випробування сформованої моделі навчання, яке задовольнимо наші потреби. Так, наша модель показала достатній результат на лекційних заняттях, але на практичних - низький, тому для практичних занять було залишено традиційну модель викладання. Структуру теоретичного заняття сформовано з елементів різних видів «перевернутого класу», яку ми зобразили у вигляді таблиці 1.

\section{Структура теоретичного (лекційного заняття)}

Таблиця 1

\begin{tabular}{|c|c|c|c|}
\hline \multicolumn{3}{|r|}{ Етапи } & \multirow[t]{2}{*}{$\begin{array}{l}\text { पас, } \\
\text { Хв. }\end{array}$} \\
\hline № & Назва & 3міст & \\
\hline 1 & Організаційна частина & $\begin{array}{l}\text { Перевірка присутності студентів на занятті та їх } \\
\text { готовності. }\end{array}$ & 2 \\
\hline 2 & Запитання від студентів & $\begin{array}{l}\text { Студенти ставлять запитання викладачу, які виникли в } \\
\text { процесі опрацювання домашнього завдання. }\end{array}$ & 15 \\
\hline 3 & Звернути увагу! & $\begin{array}{l}\text { Викладач уточнює той матеріал, де виникнули } \\
\text { найбільше питань у студентів, а також звертає увагу на } \\
\text { той, де повинні були виникнути запитання (з досвіду } \\
\text { викладача). }\end{array}$ & 15 \\
\hline \multirow{4}{*}{4} & $\begin{array}{l}\text { Проблемне запитання } \\
\text { (отримання) }\end{array}$ & $\begin{array}{l}\text { Студенти організовуються в малі групи (викладачем), } \\
\text { шляхом жеребкування отримують (групи) проблемне } \\
\text { запитання з теми (не менше 3-х). }\end{array}$ & 3 \\
\hline & $\begin{array}{l}\text { Проблемне запитання } \\
\text { (пошук відповіді) }\end{array}$ & $\begin{array}{l}\text { Студенти шукають відповідь на обране запитання. Під } \\
\text { час пошуку можуть використовувати різні джерела } \\
\text { інформації. }\end{array}$ & 10 \\
\hline & $\begin{array}{l}\text { Проблемне запитання } \\
\text { (обґрунтування відповіді) }\end{array}$ & Студенти дають відповідь та обґрунтовують ії. & 10 \\
\hline & $\begin{array}{l}\text { Проблемне запитання } \\
\text { (результати) }\end{array}$ & $\begin{array}{l}\text { Викладач дає відповіді на всі поставлені запитання та } \\
\text { обґрунтовує їх. Студенти разом з викладачем } \\
\text { виставляють оцінку за цей вид роботи. }\end{array}$ & 5 \\
\hline 5 & Тренажер формул [7] & $\begin{array}{l}\text { Студенти в парах виконують завдання «Тренажер } \\
\text { формул». }\end{array}$ & 5 \\
\hline 6 & Тестування & Студенти проходять тестування з теми & 10 \\
\hline 7 & Рефлексія & Рефрлексія студентів щодо заняття. & 5 \\
\hline
\end{tabular}

[авторська розробка]

Для кращого розуміння представимо модель викладання фрізики для студентів коледжів на темі «Електромагнітні коливання і хвилі» за планом (табл. 2). 


\section{Тематичний план теми «Електромагнітні коливання і хвилі»} Змістовий модуль 3.4. Електромагнітні коливання і хвилі

\begin{tabular}{|c|l|}
\hline \multicolumn{1}{|c|}{ Змістовий модуль 3.4. Електромагнітні коливання і хвилі } \\
\hline 1 & $\begin{array}{l}\text { Коливальний контур. Виникнення вільних електромагнітних коливань. Гармонічні } \\
\text { електромагнітні коливання. Формула Томсона. Перетворення енергії під час вільних } \\
\text { електромагнітних коливань. }\end{array}$ \\
\hline 2 & $\begin{array}{l}\text { Змінний струм як вимушені електромагнітні коливання. Конденсатор і котушка в колі } \\
\text { змінного струму. Активний, ємнісний та індуктивний опори. Робота й потужність змінного } \\
\text { струму. Діючі значення напруги та сили струму. Трансформатор. Виробництво, передача } \\
\text { та використання енергії змінного струму. }\end{array}$ \\
\hline 3 & $\begin{array}{l}\text { Електромагнітні хвилі, їх утворення та поширення. Висновки з теорії Максвелла, досліди } \\
\text { Герца. Швидкість поширення електромагнітних хвиль. Принципи радіотелефонного } \\
\text { зв'язку. Радіомовлення та телебачення. }\end{array}$ \\
\hline 4 & \multicolumn{1}{|c|}{ Практична частина } \\
\hline 5 & Практикум з розв'язування задач №3.4.1 \\
\hline 6 & $\begin{array}{l}\text { Практикум з розв'язування задач №3.4.2 } \\
\text { Козв'язування задач (підготовка до к/р). }\end{array}$ \\
\hline
\end{tabular}
Дані сорормовано з [6]

Домашнє завдання на перше заняття теми (наступні): опрацювати теоретичний матеріал Лекція 3.4.1 (Лекція 3.4.2, Лекція 3.4.3) на платформі Moodle курсу «Фізика і астрономія. 2 курс», та переглянути Відеоматеріали до Лекції 3.4.1 (Відеоматеріали до Лекції 3.4.2, Лекції 3.4.3) (рис. 1).

Теоретичний матеріал

级

Лекція 3.4.12 курс 1.2м6 документ PDF

级

Лекція 3.4.2 2 курс 1.6Мб документ PDF

级

Лекція 3.4.32 курс 1.6мб документ PDF

Матеріал для практичного виконання

Буклет "Шкала електромагнітних хвиль"

Контрольна робота

囱 Контрольна робота 3.4 (4 рівень та встановл. відповід.) 2 курс 497 Кб документ PDF

Контрольна робота 3.4 (Задачі) 2 курс 417.5К6 документ PDF

Контрольна робота 3.4

Відеоматеріали до Лекції 3.4 .1

Відеоматеріали до Лекції 3.4 .2

Відеоматеріали до Лекції 3.4.3

Рис. 1. Скрін курсу «Фізика і астрономія» на платформі Мoodle коледжу 
Створена модель заняття сприяє формуванню багатьом компетентностям майбутнього професіонала, серед яких інформаційно-комунікаційна, навчання впродовж життя, тощо [5]. На кожному етапі структури лекційного заняття здійснюється робота з інформацією: отримання, опрацювання, узагальнення, ретранслювати та застосовувати у практичній діяльності.

Так, дана модель показала свої преваги і недоліки:

- Не можна бути впевненим, що кожен студент виконує завдання вдома, тому в моделі присутні етапи 2 і 3 (табл. 1);

- Під час роботи студентів на етапах 4 та 5 (табл. 1) не можна бути впевненим, що всі студенти працюють «на всі $100 \%$ \%.

- Студенти не розуміють поставленого проблемного запитання, тому що, читаючи його, доходять до знайомого слова і не дочитують його до кінця.

- Студенти не вміють будувати відповідь на поставлене запитання, а також виникають великі проблеми в обґрунтуванні їі.

Для вирішення недоліків було розроблено методичні рекомендації, щодо використання даної моделі викладання:

- Модель можна використовувати лише зі згоди студентів (в нашому випадку модель обрали близько $84 \%$ студентів курсу).

- Провести одну тему за даною моделлю і, за результатами роботи, провести повторне опитування студентів (в нашому коледжі - близько 92\%).

- Попередньо розробити дистанційний курс для виконання домашнього завдання.

- На етапах 4, 5, 6 (табл. 1) викладачу потрібно виконувати роль контролера та робити замітки з приводу активності кожного студента.

- Для малоактивних студентів (а такі будуть) запропонувати окремі завдання на ту оцінку, яку вони бажають отримати за тему.

- На перших етапах впровадження/використання потрібно допомагати студентам у формуванні відповіді на запитання, а також їі обґрунтуванні.

- Розробити свою систему оцінювання кожного етапу лекційного заняття 3 переведенням в систему, яку використовує заклад (4-х бальна $(2,3,4,5)$ чи 12-ти бальна, тощо).

- Включити проблемні запитання, опрацьовані під час лекційного заняття в контрольну роботу з теми.

- Нашу модель заняття «Перевернутого навчання» використовуйте 3 адаптацією до ваших потреб та завдань.

\section{Список використаних джерел:}

1. Гунченко, М. А. (2019). Перевернуте навчання. Всеосвіта. Вилучено 3 https://vseosvita.ua/library/perevernute-navcanna-61118.html

2. Дишлєва, С. (2019). Інформаційно-комунікаційні технології (ІКТ) та їх роль в освітньому процесі. Освіта.иа. Вилучено з http://osvita.ua/school/method/technol/6804/

3. Лабораторна робота 1. (2019). Інформаційно-освітній портал кафеедри інноваційних та інфформаційних технологій в освіті Навчально-наукового інституту педагогіки, психології, підготовки фахівців вищої кваліфікації Вінницького державного педагогічного університету імені Михайла Коцюбинсько. Вилучено з http://ito.vspu.net/ENK/20112012/kompleks_new_magistru/lab_rob/lab_rob_1.htm???history=0\&pfid=1\&sample=4\&ref=1 
4. Практичні поради щодо організації навчання за моделлю «Перевернутий клас». (2019). На Урок. Освітній проект. Вилучено $3 \mathrm{https} / / /$ naurok.com.ua/post/model-navchannyaperevernutiy-klas-zminyuemo-osvitniy-proces

5. Про освіту (Закон України). https://zakon.rada.gov.ua/laws/show/2145-19

2145-VIII. (2017). Вилучено 3

6. Фізика. Навчальні програми для загальноосвітніх навчальних закладів. (2018). Вилучено з https://mon.gov.ua/storage/app/media/zagalna\%20serednya/programy-10-11-klas/20182019/fizika-10-11-avtorskij-kolektiv-pid-kerivnicztvom-lokteva-vm.pdf

7. Щур, Н. В. (2019). Тренажери формул. ФІЗИКА НОВА. Вилучено з https://www.fizikanova.com.ua/trenazhery

DOI 10.36074/13.12.2019.v3.08

\title{
ПІЗНАВАЛЬНА АКТИВНІСТЬ ЯК ОСНОВА РОЗВИТКУ ТВОРЧОЇ ДІЯЛЬНОСТІ МАЙБУТНЬОГО ВЧИТЕЛЯ МУЗИЧНОГО МИСТЕЦТВА
}

\author{
Молчанова-Долінко Валерія Олександрівна \\ аспірантка кафедри педагогіки \\ Криворізький державний педагогічний університет
}

НАКОВИЙ КЕРІВНИК:

Мішеніна Тетяна Михайлівна доктор педагогічних наук, професор Криворізький державний педагогічний університет

УКРӒ̈HA

Постановка проблеми. Специфіка професійно-педагогічної самореалізації майбутнього учителя музичного мистецтва відбувається під час творчої діяльності. Особистісний і професійний розвиток спеціалістів нерозривно пов'язаний із рівнем пізнавальної активності, а саме зі створенням такого сучасного навчального середовища, яке сприятиме постійному збільшенню потреби до процесу пізнання.

Аналіз основних досліджень. Питання пошуку професіонального становлення майбутнього учителя розглядається в різних аспектах. В сучасних наукових працях з різних теоретичних поглядів розкриті соціальнопедагогічні й психодидактичні умови розвитку пізнавальної активності студентів (М.Богомолова, І.Журавльов, О.Зоріна, І.Логвінов, Т.Тихомирова). Визначена характеристика суб'єктності студента як усвідомлена регуляція пізнавальної діяльності (К. Абульханова-Славська, І.Зязюн, І.Лернер, М.Махмуров, І.Лернер, М.Скаткін, Н.Тализіна). Розвиток творчості як основи розумової діяльності розкривають психологи й педагоги (Ю.Бабанський, Н.Давидюк, І.Зімняя).

Як доводять спостереження, одним із важливих психодидактичних умов $€$ стимулювання студента-музиканта до творчої виконавської діяльності та виконання навчально-дослідної й науково-дослідної роботи. Ця проблема $\epsilon$ недостатньо розкрита в науковій літературі, незважаючи на її практичний запит. 
Мета статті полягає у визначенні теоретичної сутності пізнавальної активності як основи розвитку творчої пізнавальної діяльності майбутнього вчителя музичного мистецтва.

Виклад основного матеріалу. У процесі визначення сутності творчої пізнавальної діяльності студента-музиканта ми враховували досягнення розвивального навчання, яке передбачає врахування законів опосередкування (за Л.С.Виготським) як процесу соціогенезу особистості майбутнього фрахівця. Такий підхід давав можливість здійснити перехід від соціальних (навчально-виконавчих зразків) до індивідуально визначених стилів музичного виконання.

Під час дослідження ми дотримались основного принципу розвивального навчання - суб'єктність в навчальному процесі, а це є вміння вчитися, бажання вчитися, самостійно організовувати навчання за принципом рефлексії (за висловом В. Слободчикова).

Для проведення експериментально-емпіричної роботи була здійснена індивідуальна тематична бесіда з викладачами музики з метою дотримання принципу взаємозв'язку навчального моделювання $i$ навчального співробітництва як двох важливих складових навчальної діяльності.

Результатом такого співробітництва є вміння студента виступати суб'єктом навчального процесу, а значить вміти планувати й виконувати відповідні завдання для досягнення кінцевого результату. За К. Абульхановою Славською, суб'єктна активність у навчанні обумовлює творчу активність як прояв індивідуальності студента, що відповідає природному його розвитку [1].

У професійній підготовці майбутнього вчителя музики важливим $є$ вміння залучити учнів до естетичного споглядання, емоційного переживання, інтуїтивного осягнення багатозначних життєвих ситуацій, виражених різноманітними художніми образами через призму творчого процесу навчання.

М. Лісіна вважає, що пізнавальна активність займає в структурі діяльності місце, наближене до рівня потреби. За М. Лісіною, до пізнавальної активності близьким є поняття допитливості, або цікавості [2].

В. Лозова дослідила феномен пізнавальної активності - як риси особистості, яка виявляється у ії ставленні до пізнавальної діяльності, що передбачає стан готовності, прагнення до самостійної діяльності, спрямованої на засвоєння індивідом соціального досвіду, накопичених людством знань і способів діяльності, а також знаходить вияв у якості пізнавальної діяльності [3].

Пізнавальну активність як різновид соціальної активності розкриває Е. Ярославова. Вона вважає, що пізнавальна активність - це складне особистісне утворення, яке виявляється і формується в діяльності. Пізнавальна активність відображає рівень діяльності, її якість і характер. Вона спрямована на отримання, переробку і засвоєння інформації, що стосується різних сторін дійсності і самої людини [4].

Звернемо увагу на те, що деякі автори вважають вищим рівнем розвитку пізнавальної активності творчу активність. Вони виходять з того, що творчість $\epsilon$ вищою фрормою будь-якої активності (соціальної, пізнавальної, трудової, естетичної), а також самовдосконалення особистості. Тоді творча активність це складне відношення людини до дійсності, комплекс її властивостей, де в єдності виступають інтелектуальні, вольові, емоційні процеси. Творча активність при цьому тлумачиться як прагнення студента зануритись у сутність речей, явищ, прагнення до застосування нових прийомів переборення 
труднощів, здібність вносити елементи новизни у способи виконання навчальних завдань, вирішення задач.

Висновок. Зазначимо, що розглянувши структурні компоненти пізнавальної активності ми можемо зробити теоретичний аналіз проблеми пізнавальної діяльності особистості в навчанні, яка потребує принципового осмислення основних елементів навчання (зміст, форма, методи) і направляє нас на думку, що метою активізації навчання майбутнього вчителя музичного мистецтва є створення таких педагогічних умов професійно пізнавальної активності суб'єкта, в результаті яких студент виходить на рівень саморозвитку і самовдосконалення власної професійності

\section{Список використаних джерел:}

1. Абульханова-Славская, К.А. (1999). Психология и сознание личности. Изб.психологические труды. М.: МПСИ; Воронеж: МОДЭК.

2. Лисина, М. И. (1982). Развитие познавательной активности детей в ходе общения со взрослыми и сверстниками. Вопросы психологии, (4), 18-35.

3. Лозова, В. І. (2000). Цілісний підхід до формування пізнавальної активності школярів. Харківський державний педагогічний університет імені Г. С. Сковороди. - 2-ге вид., доповн. Харків: ОВС.

4. Ярославова, Е. Н. (1999). Факторы формирования познавательно-профрессиональной активности студентов: на примере изучения иностранного языка: (автореф. дис. ... канд. пед. наук: спец.: 13.00.01). Челябинск.

\section{ПРОБЛЕМНІ АСПЕКТІВ НАСТАВНИЦТВА У ПЕДАГОГІЧНОМУ КОЛЕКТИВІ ВИЩОГО ВІЙСЬКОВОГО НАВЧАЛЬНОГО ЗАКЛАДУ}

\section{Дзюба Петро Миколайович}

канд. пед. наук, доцент, доцент кафедри загальновійськових дисциплін Національна академія Державної прикордонної служби України імені Б. Хмельницького

УКРÄ̈HA

Одним 3 напрямів методичної роботи 3 молодими викладачами $€$ організація наставництва. В сучасному сенсі наставник - це той, хто використовує ресурси і внутрішній потенціал підопічного для досягнення конкретних цілей.

Міжнародним та вітчизняним досвідом встановлені найбільш поширені проблемні аспекти та труднощі у досягненні ефективної наставницької діяльності у вищих навчальних закладах. [1], [2]

Перша проблема $є$ концептуальною. Вона стосується виважених зв язків наставників 3 керівництвом педагогічних колективів. Методи роботи 3 підлеглими керівника принципово відрізняються від підходів до діяльності наставника. Спроба навіть часткового перекладення функцій та методів роботи керівника на наставника зводить ефективність роботи останнього нанівець. Якщо діяльність наставника ще заформалізувати офріційними 
планами, щоденниками, звітами, то кращим буде його зовсім не призначати. Тому, в першу чергу, необхідно принципово перепрацювати відповідні діючі керівні документи по наставництву, з урахуванням наукових обґрунтувань та досягнень у цій сфрері. [3], [4] Основою для них можуть стати базові підходи, які викладені у першому розділі. В педагогічних колективах одному наставнику доцільно призначати не більше двох викладачів - початківців. Термін їх співпраці слід визначати лише орієнтовно, наприклад, - у межах 2-3 років.

Друга проблема стосується забезпечення зацікавленості наставників в добросовісній співпраці з підопічними.

За великим рахунком, у педагогічних колективах наставник працює 3 підопічним не стільки за матеріальну вигоду, скільки за покликанням. Тому можна внести до першої частини їх індивідуального плану витрати часу на наставництво у межах 80-160 годин. При цьому більша кількість годин призначається на першому році співпраці наставника з підопічним, а менша на останньому році.

Надати право начальникам кафедр за вище наданими критеріями визначати виправданість витрат часу наставником. Якщо його діяльність протягом року була успішною, то начальником кафедри цей обсяг годин наставнику зараховується, якщо ні - то відповідно зменшується, або не враховується.

Безумовно, що внесення вказаного обсягу годин роботи наставника у його навчальне навантаження не вирішує всі проблеми ефективної підготовки викладачів - початківців. Але краще вирішувати проблеми по мірі їх надходження. Розпочати потрібно з активізації мотивації до наставницької роботи досвідчених викладачів.

Третя проблема полягає у необхідності навчання наставників. У сучасних умовах, коли ростуть вимоги до особистісних якостей педагогів, наставникам необхідні комунікативні навички, які б вони могли ефективно застосовувати. Вбачається доцільним розробити робочу програму підготовки наставника, диференційовану для роботи з викладачами - початківцями на першому, другому і третьому роках їх становлення на посадах. Дану програму можна назвати, наприклад, «Культура викладацької праці», чи «Викладання. Спадкоємність поколінь», або «Викладацька інтелігенція. Вчора, сьогодні, завтра». Визначити в цій програмі ряд тем, обов'язкових для засвоєння, а також теми, які наставник зможе вибрати, виходячи з власної компетенції і потенціалу підопічного. Одночасно необхідно залишити йому можливість для творчості в рамках самостійного підбору інформації.

Четверта проблема полягає у необхідності проведення ретельного відбору претендентів на роль наставника на основі тестування і співбесід 3 залученням психологів. Було б доцільним проведення підрозділом психологічного забезпечення відповідних семінарів - тренінгів з кандидатами у наставники, де визначати їх придатність до такої делікатної діяльності, а також для навчання останніх. Основою відбору кандидатів на роль наставника повинні бути найбільш важливі для них якості. Не менш важливою $є$ необхідність надання відібраним кандидатам у наставники базових теоретичних знань з наставництва, а також найбільш вагомих та ефективних практичних рекомендацій. 
Таким чином, наставництво у педагогічних колективах це одна 3 найважливіших та найефективніших складових частин цілеспрямованої системи адаптації викладача - початківця до високопродуктивної педагогічної діяльності.

\title{
Список використаних джерел:
}

1. Materialyi nauchno - metodicheskoy konferentsii «Vospitanie v usloviyah vuzovskogo sotsiuma»: vyipusk 1 (2005). Tomsk: TPU. [in Russian].

2. Moskalenko A.P., Kobzin D.O. (2000) Profesiina adaptatsiia pratsivnykiv OVS: metodychni rekomendatsii. Kharkiv: Universytet vnutrishnikh sprav. [in Ukrainian].

3. Nakaz ministra vnutrishnikh sprav Ukrainy vid 12 chervnia, 1993 r., № 367. «Polozhennia pro nastavnytstvo v orhanakh vnutrishnikh sprav Ukrainy». (2003).Kyiv: MVS. [in Ukrainian].

4. Nakaz rektora Natsionalnoi akademii Derzhavnoi prykordonnoi sluzhby Ukrainy vid «30» serpnia 2018 roku № 195 «Instruktsiia z planuvannia ta obliku diialnosti naukovo-pedahohichnoho skladu Natsionalnoi akademii Derzhavnoi prykordonnoi sluzhby Ukrainy imeni Bohdana Khmelnytskoho.(2018). Khmelnytskyi: NADPSU. [in Ukrainian].

\section{ПРОЕКТНА ДІЯЛЬНІСТЬ ЯК СПОСІБ ОРГАНІЗАЦІЇ РОБОТИ МОЛОДШИХ ШКОЛЯРІВ НАД ТЕКСТОМ}

\begin{abstract}
Шевчук Лариса Миколаївна
кандидат педагогічних наук, старший науковий співробітник відділу навчання мов національних меншин та зарубіжної літератури Інститут педагогіки НАПН України
\end{abstract}

УКРӒ̈HA

В умовах сучасного суспільства ширші перспективи має людина, яка здатна нестандартно мислити, генерувати різноманітні ідеї та втілювати їх. Водночас, для сьогодення характерний постійно зростаючий об'єм інфрормації, що мотивує необхідність підготовки у навчальних закладах учнів, які вміють самостійно й активно здобувати знання, - шукати та опрацьовувати потрібні тексти, створювати їх.

Перелічені вище аспекти характерні для проектної діяльності як способу організації самостійної роботи молодших школярів над текстом, що ґрунтується на безпосередній пізнавальній активності і самостійності школярів, сприяє формуванню їхньої комунікативної та інформаційної компетентностей, уміння вчитися тощо.

Аналіз попередніх досліджень свідчить, що проблему використання методу проектів у навчально-виховній діяльності досліджували зарубіжні та вітчизняні науковці, починаючи з минулого століття. Зокрема метод проектів описували його засновники Дж. Дьюї, В. Кілпатрик; становлення методу проектів як способу організації навчання, його використання в освітньому процесі Г. Ващенко, І. Єрмаков, Л. Левін, О. Пометун; загальні засади методу, його різновиди, методичні особливості застосування - Г. Голуб, О. Грєбєннікова, В. Гузєєв, Л. Колєснікова, Е. Коллінгс, М. Морозова, Є. Пєрєлигіна, Є. Полат, 
В. Симоненко, О. Чуракова, С. Шевцова; використання у навчальновиховному процесі початкової школи - О. Онопрієнко та ін.

Утім, спостерігається недостатність досліджень з проблеми організації проектної діяльності, що передбачає роботу молодших школярів над текстом, що спричинює актуальність розгляду цієї проблеми.

Сучасні науковці розглядають навчальний проект як особистісно орієнтовану технологію, спосіб організації самостійної діяльності учнів, форму організації діяльності, спрямованої на одержання практично або теоретично значущого результату [1; 3]. «Навчальний проект - це дидактичний засіб, за допомогою якого учні долучаються до перетворювальної діяльності, яка передбачає формулювання проблеми й мети, планування змісту, з'ясування засобів і способів, одержання продукту діяльності.» [2]

Використання методу проектів сприяє виникненню стійкої мотивації до навчання, активізації пізнавальної самостійності, реалізації діяльнісного та особистісно орієнтованого підходів, подоланню протиріччя між колективним способом навчання та індивідуальним характером сприймання, засвоєння інформації, формування умінь і навичок; організацією зворотного зв'язку між учителем і учнями. Водночас позитивними аспектами застосування методу проектів $є$ покращення якості знань учнів, розвиток їх критичного мислення, творчих здібностей, комунікативних умінь, створення умов для самореалізації, виховання відповідальності, самодисципліни, самоорганізації, умінь працювати в команді тощо. Крім того, під час роботи над проектом учні навчаються намічати проміжні завдання, шукати та реалізовувати шляхи їх вирішення, за необхідності коригувати власну діяльність, у той час як вчитель координує роботу школярів, підтримує та заохочує їх.

Обираючи проектну діяльність як спосіб організації учнів початкових класів над текстом, варто враховувати, що їі організація містить такі етапи:

1) підготовчий етап - занурення у проблему, обмін знаннями з теми, ідеями, висловлювання побажань, питань; усвідомлення теми і визначення мети проекту, прогнозування результатів; мотивування важливості виконання;

2) етап планування - вироблення плану дій, визначення часових рамок, що обмежують етапи роботи над проектом, обговорення варіантів звітності про виконану роботу, розподіл доручень;

3) виконання проекту - колективна, індивідуальна діяльність учнів, спостереження вчителя за роботою школярів, надання допомоги та здійснення корекції (за необхідності); аналіз та систематизація напрацьованих матеріалів, підготовка їх до презентації;

4) підсумковий етап - представлення учнями результатів проекту (презентація), його публічний захист; обговорення та узагальнення одержаних результатів, процесу виконання проекту, формулювання висновків, оцінювання результатів.

Уточнимо, що планування проектної діяльності, що передбачає роботу над текстами, має двоетапний характер:

$>$ загальне планування, яке здійснюється за участю всіх учасників проекту спільно з учителем (визначення окремих етапів роботи, послідовності їх виконання, кількості учасників у групах, завдань для учасників, термінів виконання і форми представлення результатів роботи);

$>$ планування роботи без участі вчителя (розподіл обов'язків між членами групи, встановлення термінів і послідовності виконання отриманих частин 
завдання тощо).

Успішність використання у навчально-виховному процесі початкової школи методу проектів під час роботи учнів над текстом потребує дотримання низки вимог:

- практична, теоретична, пізнавальна значущість проблеми (обраної для проектної діяльності), очікуваних результатів; вміст цікавих завдань, які відповідають віковим особливостям школярів;

- дотримання етапів проектної діяльності;

- створення відповідної робочої атмосфери;

-добровільне залучення учнів до проектної діяльності;

- самостійність школярів у роботі над проектом;

-дотримання часових меж виконання проекту;

-доведення розпочатих проектів до завершення, аналіз не тільки результатів, а й процесу роботи, стимулювання та заохочення школярів тощо.

Водночас, слід відзначити важливість функцій вчителя, який визначає завдання для проектної діяльності, надає школярам можливість вільно й самостійно працювати, змінюючи роль безкомпромісного контролера на роль толерантного наставника й помічника. Велике значення має наявність у вчителя відповідних знань про сутність проектної діяльності, її етапи, специфіку застосування в освітньому процесі та відповідний досвід. Разом 3 тим, успішна реалізація проекту залежить від відповідальності учасників (високий рівень особистої відповідальності учнів $є$ запорукою високого рівня якості результатів).

Для проектної діяльності учнів над текстом характерна видова різноманітність. Зокрема, за тривалістю виконання проекти можливо розподілити на короткотривалі (школярі виконують протягом уроку), середньотривалі (термін виконання - не більше одного місяця), довготривалі (більше одного місяця). Залежно від кількості учасників розрізняють індивідуальні або колективні (парні, групові) проекти. Водночас, для проектної діяльності над текстом можлива змістова різноманітність.

Приклад довготривалого проекту, що передбачає самостійне створення учнями текстів описано у педагогічній спадщині В. Сухомлинського. Видатний педагог здійснював систематичну кропітку роботу, що містила зразок творчої діяльності наставника та колективну діяльність школярів під його керівництвом. Школярі записували свої твори у спеціальні альбоми (у яких була представлена творчість учнів класу), ілюстрували. Результат такої проектної діяльності ставав доступним для ознайомлення іншим школярам, батькам, вчителям, що забезпечувало створення ситуації успіху, самореалізації, формуванню позитивної мотивації до навчання.

На нашу думку, під планування проектної діяльності, що передбачає роботу учнів початкових класів над текстом, першочерговим $€$ визначення теми і мети проекту (визначеної відповідно до вікових особливостей школярів), що у свою чергу, впливає на термін його виконання та кількість учасників. Більш конкретно це виглядає так:

Приклад 1. Проект «Книжка у подарунок» (учасники - учні 2 класу). Тривалість виконання проекту - 1 тиждень. Виконання проекту полягає у конструюванні текстів казок, оповідань із запропонованих частин, розфарбовування або малювання ілюстрацій та створення дитячих книжечок. Після короткої презентації учні школярі презентують і дарують 
першокласникам для бібліотечки класу.

Приклад 2. Проект «Тварини нашого краю» (учасники - учні 3 класу). Тривалість виконання проекту - близько двох місяців. Під час роботи над проектом школярі розподіляють між групами назви тварин, здійснюють пошук і добір книг, створення тематичної виставки «Тварини нашого краю», читання і обговорення книг під час уроків «Літературного читання», колективне визначення найбільш цікавої книги.

Приклад 3. Проект «Птахи рідного краю» (учасники - учні 4 класу). Тривалість виконання проекту - 1 місяць. Реалізація проекту передбачає пошук і добір текстів, створення тематичної стінгазети. Після розподілу між групами, про яких птахів школярі добиратимуть інформації, та роботи над проектом, здійснюється розміщення дібраних матеріалів у стінній газеті та ії розміщення у коридорі або вестибюлі (можливо, і на сайті) навчального закладу.

Приклад 4. Проект «Наші українські народні казки» (учасники - учні 4 класу). Тривалість виконання проекту - 2 тижні. Працюючи над виконанням проекту кожен із школярів обирає собі українську народну казку та змінює ії на власний розсуд, замінюючи одного або кількох героїв (або додаючи одного чи кількох героїв), змінюючи сюжет або кінцівку казки, пропонуючи продовження казки тощо.) Після завершення роботи над проектом казки презентують під час виставки, збірку казок можливо розташувати на сайті навчального закладу.

Приклад 5. Проект «Моя книга». Тривалість - 4 роки (з першого по четвертий клас). Учасниками спочатку $є$ учні з високим рівнем навчальних досягнень, згодом - кількість учасників поступово збільшується. Кожен із учнів записує, наклеює у зошит власні твори та інші творчі роботи, створює ілюстрації, аплікації та ін. Створені книги наприкінці 4 класу учні презентують під час виставки.

Підсумовуючи сказане вище варто зазначити, що під час проектної діяльності, що передбачає роботу над текстом молодші школярі можуть здійснювати самостійний пошук текстової інформації, її аналіз, узагальнення, вдосконалення та створення, що сприятиме формуванню предметних i ключових компетентностей, здатності учнів до самоосвіти, умінь осмислення і коригування результатів діяльності, розвитку їхніх творчих здібностей, самореалізації, успішності у житті тощо. Водночас, наголосимо, що для оптимального застосування проектної діяльності як способу організації роботи учнів початкових класів над текстом важливим і актуальним $€$ створення відповідних методичних посібників для учителів, навчальних посібників для школярів та їх популяризація.

\section{Список використаних джерел:}

1. Голуб, Г.Б., Перелыгина, Е.А. \& Чуракова, О.В. (2006). Метод проектов - технология компетентностно-ориентированного образования: Методическое пособие для педагогов руководителей проектов учащихся основной школы / под ред. Е.Я. Когана. Самара : Издательство «Учебная литература», Издательский дом «Федоров».

2. Дьюї, Джон.(2006). Школа і суспільство. Історія зарубіжної педагогіки : хрестоматія (укл. Є.І. Коваленко). К. : Центр навчальної літератури, 449-463.

3. Онопрієнко, О. (2009). Метод проектів як засіб розвитку пізнавальних інтересів школярів ( автореф. дис. ... на здобуття наук. ступ. канд. пед. Наук). Київ.

4. Сухомлинський, В. (1976). Серце віддаю дітям. Вибрані твори в 5 томах. Том 3. Київ : 
Радянська школа, 7-279.

5. Шевчук, Л.М. Читаємо. Розуміємо. Творимо : навчальна програма. Вилучено 3 http://www.undip.org.ua/news/library/navch_program_detail.php?ID=9285

\title{
РОЛЬ ЛЕКЦІЙНИХ ЗАНЯТЬ 3 МАТЕМАТИКИ ПРИ НАВЧАННІ СТУДЕНТІВ ІНЖЕНЕРНИХ СПЕЦІАЛЬНОСТЕЙ
}

\begin{abstract}
Калініна Ірина Миколаївна
канд. пед. наук, доцент, доцент кафедри вищої та прикладної математики ДВНЗ «Приазовський державний технічний університет»

УКРАЇHA
\end{abstract}

Система освіти, зокрема вищої, на кожному етапі розвитку суспільства піддається ретельному аналізу та реформуванню. Сучасний етап, для якого характерний стрімкий розвиток інформаційних технологій, змінює акценти 3 фрормування у майбутніх спеціалістів знань та умінь на формування компетенцій і так званих soft skills. У зв'язку з цим значною мірою змінилося співвідношення аудиторної та самостійної роботи студентів закладів вищої освіти. Однак, ці перетворення в системі освіти не дають викладачу чітких рекомендацій як діяти в цих умовах, залишаючи це на їх власний розсуд.

Багато питань та дискусій у колах викладачів виникає щодо однієї 3 основних фрорм навчання у вищому навчальному закладі - лекції. Деякі викладачі переносять частину тем на самостійне опрацювання студентами, контролюючи їх опанування на контрольних заходах. Однак наш досвід показує, що в такому випадку теми опрацьовуються студентами формально (це в кращому випадку). Частіше, вони залишаються поза їхньою увагою. I цьому $\epsilon$ пояснення. У підручниках, як правило, навчальний матеріал викладається абстрактно-дедуктивним методом, що не сприяє ґрунтовному засвоєнню навчального матеріалу студентами, які мають не дуже високий рівень математичної підготовки. Інші викладачі намагаються викласти на лекціях якомога більше інформації за рахунок того, що обмежуються лише формулюваннями означень і теорем, наводячи типові приклади. Але при такому підході втрачається зв'язок між теоретичними фрактами, а сам курс вищої математики перетворюється у купу незрозумілих для студента формул і теорем. На наш погляд, дидактична роль лекції сьогодні змінилася кардинально. Замість «викладання» інформації студентам, лектор має знайомити студентів з основними ідеями, методологією дисципліни, сформувати орієнтовну основу для подальшої самостійної роботи. Враховуючи те, що для студентів інженерних спеціальностей математика $€$ інструментом досліджень, а не предметом, потрібно, 3 одного боку, забезпечити ґрунтовне засвоєння понять, а з іншого боку, відійти від надмірної строгості. Яким чином цього можна досягти? По-перше, означення математичних понять вводити конкретно-індуктивним методом. Робота 3 виокремлення істотних ознак поняття дозволить студентам інженерних 
спеціальностей ґрунтовніше засвоїти їх. 3 іншого боку, потрібно скоротити час на доведення теорем. Взагалі не доводити математичні твердження не можна, бо в такому випадку студенти не бачать методологію науки. Ми вважаємо, що доведення теорем краще проводити у вигляді обговорення (за заздалегідь підготовленою презентацією), без запису до конспекту. Така робота дозволить краще зрозуміти складні моменти доведення, яке студент завжди зможе знайти у підручнику, виданому конспекті лекцій і т.п. Тобто лекція має перетворитися з «викладання фрактів» в їх обговорення. В деяких випадках, на наш погляд, можна відмовитися від строгих доведень, замінюючи їх на правдоподібні міркування, або геометричні інтерпретації, підкреслюючи важливість всіх умов теорем за допомогою відповідних контрприкладів. Така робота сприятиме формуванню евристичних умінь та розумінню того, що математичні методи слід використовувати вкрай уважно.

\section{Список використаних джерел:}

1. Власенко, К. В. \& Реутова, І. М. (2011). Застосування евристичних прийомів у ході лекційних занять з вищої математики для студентів ВТНЗ. Дидактика математики: проблеми i дослідження: Міжнародний збірник наукових робіт, (36), 67-72.

2. Калініна, І. М. (2018). Створення рефлексивного середовища під час лекцій з вищої математики. Наука та освіта: ключові питання сучасності: матеріали міжнародної науково-практичної конфреренції: зб. наукових праць «АОГОГ» (Т. 10, с. 28-34), 18 травня 2018 р. Чернігів: ГО «Європейська наукова платформа».

\section{РОЛЬ ПЕДАГОГІЧНОЇ ПРАКТИКИ У ПІДГОТОВЦІ СТУДЕНТІВ ДО ПРОФЕСІЙНО-ПЕДАГОГІЧНОЇ ДІЯЛЬНОСТІ}

Великдан Юлія Віталіївна

старший викладач кафедри теорії та методики технологічної освіти та комп'ютерної граффіки, заступник декана природничо-технологічного факультету з педагогічної практики ДВНЗ «Переяслав- Хмельницький ДПУ ім. Г.Сковороди» УКРӒ̈НА

Педагогічна практика у базових закладах $є$ обов'язковим компонентом процесу фахової підготовки майбутніх педагогів що є важливим етапом їхнього професійного зростання. Так як практична підготовка забезпечує встановлення безпосереднього зв'язку між теорією та практикою, то в умовах реальної професійної діяльності відбувається інтеграція теоретичних знань і практичних умінь студентів, що зумовлює оволодіння ними реальної професійної компетентності.

Основною метою педагогічної практики є:

- оволодіння студентами сучасними методами та формами професійної діяльності; 
- формування професійних умінь і навичок, необхідних для самостійного вирішення педагогічних завдань в умовах реального навчально-виховного процесу та відповідно до вимог сучасної школи;

- виховання потреби систематичного професійного самовдосконалення та всебічного розвитку особистості.

До найважливіших завдань педагогічної практики слід віднести такі: набуття професійних якостей майбутнього вчителя; поглиблення, закріплення та збагачення суспільно-політичних, психолого-педагогічних та спеціальних знань одержаних в університеті та застосування їх на практиці для виконання конкретних педагогічних завдань; психологічна адаптація в педагогічному колективі; озброєння студентів уміннями спостерігати і аналізувати навчальну діяльність, що проводиться з учнями; накопичення досвіду самостійної роботи; засвоєння нових методичних технологій; освоєння наукової організації праці вчителя; вивчення, аналіз і узагальнення передового педагогічного досвіду, а також аналіз і оцінка результатів своєї педагогічної діяльності; розвиток педагогічного мислення, любові до майбутньої професії, поліпшення своїх педагогічних здібностей; конкретизація, вдосконалення і розвиток необхідних професійних якостей майбутнього вчителя.

Педагогічна практика має великі можливості для формування творчого ставлення до педагогічної діяльності, визначення рівня професійної підготовки та профресійної спрямованості студентів. Саме на практиці студент може визначитися, наскільки правильно він обрав для себе сферу діяльності, з'ясувати ступінь співвідношення особистісних якостей із професією вчителя а також переконатися, наскільки важливим для сучасного вчителя $є$ володіння теорією та практикою освітнього процесу. Важливою частиною практики $є$ виконання творчих завдань, які стимулюють дослідницький підхід до професійної діяльності, оскільки на прикладі поглибленого аналізу однієї 3 проблем навчання студенти легше долучаються до педагогічного процесу. Творча робота сприяє фрормуванню комплексу умінь - обрати проблему, сформулювати завдання, обґрунтувати шляхи вирішення, проаналізувати 3 науково-теоретичних позицій [1].

Педагогічна практика $є$ обов'язковою складовою навчального процесу в педагогічному університеті, передбачає професійну підготовку педагогічних кадрів та підвищення їхньої кваліфікації. Педагогічна практика забезпечує поєднання теоретичної підготовки майбутніх вчителів трудового навчання з їх практичною педагогічною діяльністю в умовах загальноосвітніх навчальних закладів, сприяє формуванню творчого відношення до педагогічної діяльності, визначає ступінь його практичної підготовки та рівень педагогічної майстерності. Вона спрямована на закріплення теоретичних знань, отриманих студентами за час навчання, набуття i вдосконалення практичних навичок i умінь за відповідним напрямом підготовки та спеціальністю. Крім того, сприяє закріпленню психолого-педагогічних та методичних знань 3 дидактики, теорії виховання, загальної, вікової та педагогічної психології та інших фрахових дисциплін.

Отже, педагогічна практика надає студентам, майбутнім фахівцям, можливість перевірити власний рівень теоретичної підготовленості з фахових дисциплін, закріпити вироблені вміння та перевести їх у автоматизовані 
навички, оцінити свої здібності стосовно профресійної придатності та усвідомити потребу в пізнанні нового.

А також, педагогічна практика у вищих навчальних закладах $є$ не лише важливим засобом підготовки фахівців, майбутніх вчителів, а й провідним чинником саморозвитку, формування індивідуально-творчих можливостей у здійсненні педагогічної діяльності, підвищення рівня професійності та педагогічної майстерності.

\section{Список використаних джерел:}

1. Богославська, Є. М. (2013). Роль педагогічної практики у професійній підготовці майбутнього вчителя фізики. Фізико-математична освіта. Науковий журнал, (1), 5-9.

\section{САМОСТІЙНА РОБОТА СТУДЕНТІВ 3 ОХОРОНИ ПРАЦІ}

\section{Литвин Андрій}

канд. пед. наук, доцент кафедри теорії та методики професійної підготовки ДВНЗ «Переяслав-Хмельницький державний педагогічний університет імені Григорія Сковороди»

УКРÄ̈HA

Сучасна система вищої освіти покликана не лише надати студентам певний обсяг знань, сфрормувати відповідні вміння та навички, але й розвивати творче мислення, ознайомити з методикою самостійного здобуття та аналізу інформації, необхідної для подальшого професійного саморозвитку та вдосконалення. Відповідно до сучасних тенденцій вдосконалення фахової професійної підготовки, зменшується частка прямої передачі знань під час аудиторних занять, а натомість, збільшується обсяг самостійної роботи студентів.

Поняття «самостійна робота» розкрито у роботах Л. Жарова, І. Лернера, Н. Тализіної. Самостійну роботу студентів, як особливу форму навчальної діяльності суб'єкта, у процесі якої студенти набувають знання та вміння, розвивають самостійність та активність розглядали А. Алексюк, П. Підкасистий, О. Савченко, Д. Тетеріна. Навчання студентів вмінню самостійно планувати свою пізнавальну діяльність досліджували А. Лошак, О. Козак, М. Красницький.

Аналіз публікацій з даної проблеми переконливо свідчить про її важливу роль для педагогічної теорії й освітньої практики. Адже самостійна робота, як пише В.Ягупов, «має надзвичайно важливе значення для формування й удосконалення знань, мислення й переконань». Тому, на глибоке переконання вченого, «цей метод $є$ внутрішньою основою будь-якого іншого методу навчання і необхідною передумовою дидактичного зв'язку різних методів навчання між собою». Він спеціально підкреслює, що «сучасні освітні процеси і науково-технічна революція роблять метод самостійної роботи одним 3 основних» [3, с. 344]. Особливо важливого значення самостійна робота 
набуває у закладах вищої освіти, яка здійснює не тільки освіту, але й головним чином професійну підготовку майбутніх фахівців.

В. Андрєєва, розглядаючи питання самостійної роботи, пропонує таке формулювання: «Самостійна робота студентів - це така форма навчальновиховного процесу, яка охоплює поза аудиторну і аудиторну діяльність, будьякий вид самостійної навчальної чи комунікативної діяльності, що виконується в режимі взаємоконтролю...» [1].

Вища школа все більш стикається з проблемою низького рівня знань у значної частини випускників закладів вищої освіти і вкрай низькою їх мотивацією до навчання. Однією з причин цього стану ми вважаємо втрату інтересу до знань й до освіти взагалі та їх ціннісного сприйняття в суспільній свідомості. Практика ж свідчить, що вже перші успіхи студента, отримані в процесі самостійної роботи, посилюють його інтерес до навчання. При цьому виникає цікавий ефект: успішне самостійне виконання певного завдання стимулює інтерес, який, у свою чергу, сприяє бажанню успішно виконувати й наступні завдання. Цілеспрямоване використання педагогом цього ефекту вимагає обов'язкового використання заохочення студента. Тому належна організація самостійної роботи повинна включати системний контроль і об'єктивну оцінку діяльності студента.

У відповідності з Національною доктриною розвитку освіти України в XXI столітті біля 50 \% навчальної роботи передається студентам закладів вищої освіти на самостійну навчальну діяльність таким чином, самоосвіта, самостійна навчальна діяльність студентів виростає в соціальну категорію [2].

Працюючи самостійно, студент змушений повсякчас передбачати і оцінювати як можливий результат, так і саме виконання завдання, адже вона формує самостійність не тільки як сукупність певних вмінь і навичок, а як риси характеру, яка відіграє істотну роль у структурі особистості сучасного студента. Зміна концептуальної освіти й розширення функції самостійної роботи студентів не тільки веде до збільшення їі обсягу і важливості, а й викликає зміну у взаємовідносинах між викладачем і студентом як рівноправними суб'єктами навчальної діяльності, тобто коригує всі психологопедагогічні (організаційні, методичні) засоби забезпечення самостійної роботи студентів. Особливе значення має самостійна робота студентів в період підготовки до практичних та лабораторних занять, оскільки вона передбачає великий обсяг самостійності кожного студента в навчально-пізнавальній діяльності. Під час організації самостійної роботи студентів слід враховувати їх особистісні характеристики, рівень розвитку особистості.

Висновок. Таким чином, самостійна робота студентів охорони праці сприяє поглибленню і розширенню їхніх знань, фрормуванню інтересу до пізнавальної діяльності, оволодінню прийомами процесу оволодіння новими вміннями та навичками. Вона $є$ основою самоосвіти майбутнього фахівця, формує відповідну мотивацію і навички самоосвіти. Самостійна робота - це важливий засіб розвитку вмінь студентів діяти без сторонньої допомоги, їх пізнавальних здібностей і навчальних інтересів до охорони праці. Вона $€$ важливою ланкою у цілісній системі формування професійної підготовки майбутнього фахівця охорони праці. 


\section{Список використаних джерел:}

1. Андреева В. М. (1989) Методика активизации самостоятельной работы студентов ускоренного обучения. Организация самостоятельной работы в процессе изучения общественных наук. Вып. 6. Л.: Изд-во ЛГУ. С. 24-28.

2. Державна Національна програма: Освіта (Україна XXI ст.). К.: Райдуга, 1994. 49с.

3. Ягупов В. В. (2002). Педагогіка: Навч. посібник. К.: Либідь. 560 с.

\section{CEPBIC LEARNINGAPPS ЯК ЗАСІБ ОРГАНІЗАЦІї ФОРМУВАЛЬНОГО ОЦІНЮВАННЯ}

Стечкевич Софія Олегівна

здобувач вищої освіти фракультету педагогічної освіти Львівський національний університет імені Івана Франка

Стечкевич Олег Орестович

канд. пед. наук, ст. наук. сп., доцент кафедри педагогіки та інноваційної освіти Національний університет «Львівська політехніка»

УКРӒ̈HA

Реалізація індивідуального підходу, за яким кожен учень може пройти свою індивідуальну траекторію, у комфортному середовищі й темпі, передбачає перехід на особистісно-орієнтовані технології навчання. Важливе місце серед цих технологій обіймають інформаційно-комунікаційні та технології контролю, які поступово реалізовуються в Новій українській школі (НУШ).

Одним із видів контролю, який дозволяє учням усвідомлювати й відслідковувати особистий прогрес, а також планувати подальші кроки, є формувальне оцінювання. 3 огляду на вікову особливість молодших школярів (сприймають оцінку як оцінювання себе), учитель має уміти здійснювати формувальне оцінювання, яке включає як доброзичливе ставлення до самого учня, так і позитивне ставлення до зусиль учня [1]. Отриману в результаті такого оцінювання інформацію, учителі використовують для корекції плану навчання та забезпечення правильного виконання учнями індивідуальної траекторії навчання.

Зважаючи на той факт, що формувальне оцінювання - це інтерактивне оцінювання прогресу учнів в їх навчальній діяльності, пропонуємо вчителям молодших класів скористатись сервісом LearningApps [2].

LearningApps.org - один із численних онлайнових сервісів для створення інтерактивних вправ, які можна використовувати для роботи з інтерактивною дошкою. Ці вправи - чудова можливість самостійної перевірки та закріплення знань в ігровій формі. До переваг даного сервісу слід віднести: інтерфейс українською мовою; відсутність абонентської плати за користування; робота в класах; формування звітів про виконану роботу. Опишемо основні види роботи на сервісі: реєстрація, пошук та створення вправ.

Реєстрація на сервісі: кнопка «Реєстрація» $\rightarrow$ кнопка «Створити новий обліковий запис» $\rightarrow$ вигадуємо Логін $\rightarrow$ вводимо діючу електронну поштову скриньку $\rightarrow$ вигадуємо пароль $\rightarrow$ погоджуємося з правилами $\rightarrow$ кнопка 
«Створити обліковий запис». Якщо логін вже використовується (з'явиться відповідне повідомлення) - вигадуємо інший (рис. 1).

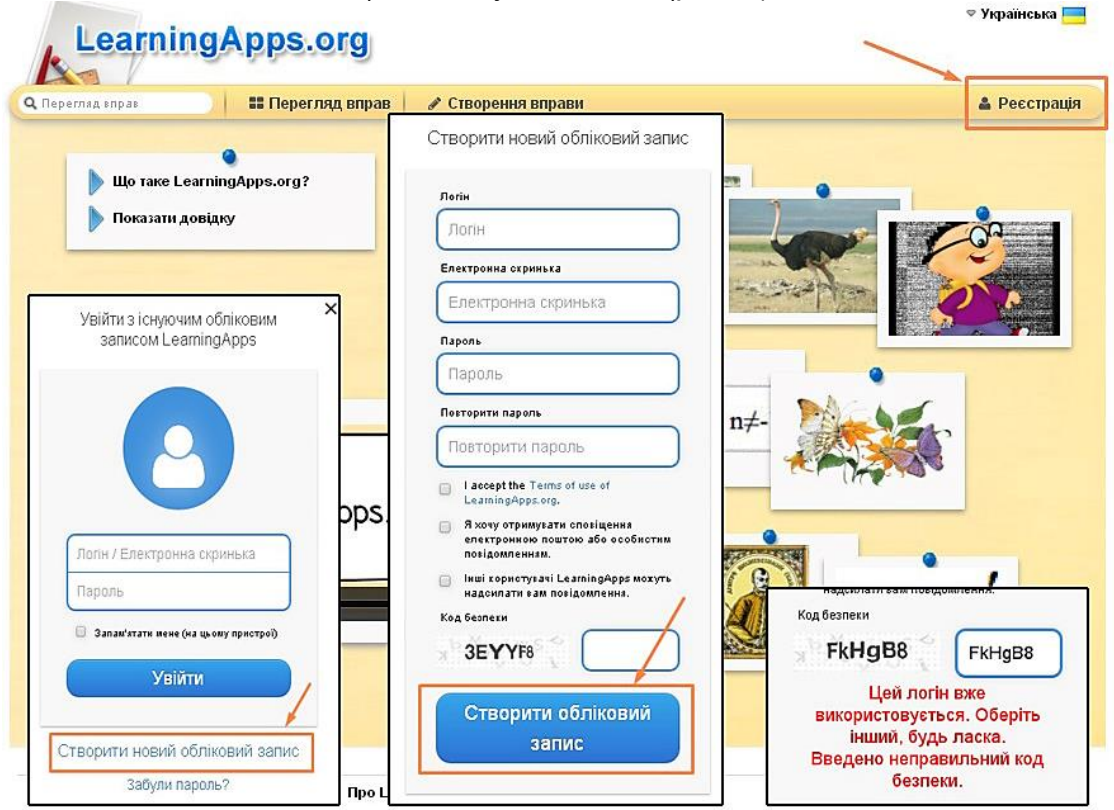

Рис. 1. Реєстрація на сервісі LearningApps

Після реєстрації можна внести зміни в обліковий запис через кнопку «налаштування профрілю» (див. рис. 2): дані про школу та сайт, ім'я та прізвище. Окрім того, профріль дозволяє налаштувати відображення поштової скриньки та отримання сповіщень. Це ж діалогове вікно дає можливість «видалити обліковий запис».

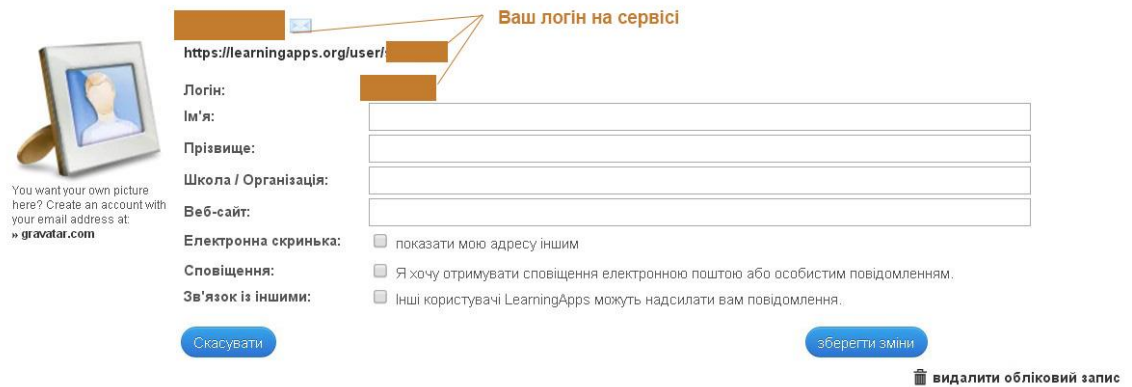

Рис. 2. Налаштування даних профілю 
78 Problems and prospects of implementation of innovative research results $\bullet$ Volume 3

Пошук вправи: кнопка «Перегляд вправ» (1) $\rightarrow$ обрати категорію $(2) \rightarrow$ ввести ключове слово і здійснити пошук (3). За допомогою повзунка (4) можна обмежити пошук за рівнем вправи для «дошкільна освіта» (рис. 3).

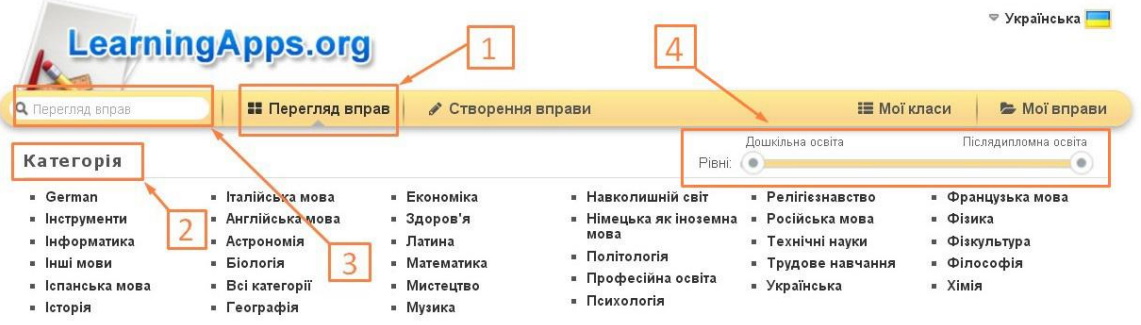

Рис. 3. Пошук вправ на сервісі

Для перегляду вправи на ній натискають ліву кнопку мишки. Під самою вправою розміщена наступна інформація (див. рис. 4): інформація про автора (1); веб-посилання, яким можна ділитися з учнями (2); веб-посилання на повноекранний перегляд (3); скачування коду для інтегрування вправи до інших ресурсів (4); QR-код для доступу до вправи (5); кнопка збереження до своєї колекції вправ (6); кнопка скачування пакету Scorm (7); кнопка створення схожої вправи (8).

Створення вправи: кнопка «Створення вправи» $\rightarrow$ вибір типу вправи $\rightarrow$ задання параметрів вправи. Розглянемо для прикладу, створення вправи типу «Класифрікація»: вказуємо назву вправи (Голосні та приголосні звуки) та опис завдання (Визначте тип звуку); задаємо 2 групи (Голосні, приголосні) та їх фон (екран вправи може ділитися на 2-4 групи, а фоном - завантажене зображення або текст); наповнюємо елементи групи: вносимо голосні та приголосні звуки у відповідні групи; ввносимо текст зворотнього зв'язку («Чудово! Тобі сьогодні все вдалося!»); у блоці «Довідка» можна вказати підказку («А спробуй проспівати...»).

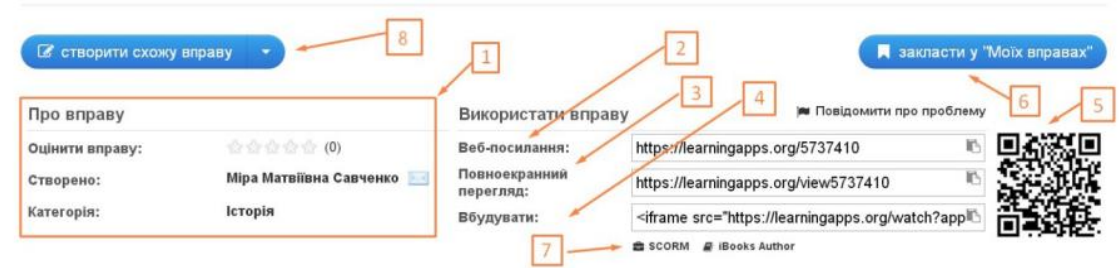

Рис. 4. Інформація про вправу

Створені вправи можна редагувати, переміщувати у дереві власних папок, визначити кількість переглядів, видаляти. Їх можна призначити для виконання (кільком класам). Створені вправи за замовчуванням мають статус «приватні» (їх бачить автор; учні класів або ті, хто отримав пряме посилання).

Висновки. Навчання й оцінювання - нероздільні процеси. Формувальне оцінювання підтримує впевненість учнів у тому, що кожен із них здатен 
покращити свої результати. Дидактичні матеріали, створені за допомогою cepвicy LearningApps, можна використовувати на уроках не лише для опитування, а й як наочність для вивчення нового матеріалу. Вони підійдуть для повторення й узагальнення вивченого, підготовки до підсумкового контролю.

\section{Список використаних джерел:}

1. Формувальне оцінювання в НУШ для 1 класу (2019). Вилучено з: https://www.pedrada.com.ua/article/2337-yak-zdysnyuvati-formuvalne-otsnyuvannya-uchnv-1klasu

2. LearningApps.org (2019). Вилучено 3: https://learningapps.org/about.php

\section{СКРАЙБІНГ У ОРГАНІЗАЦІЇ НАВЧАЛЬНО-ПІЗНАВАЛЬНОЇ ДІЯЛЬНОСТІ ШКОЛЯРІВ 3 XIMIÏ}

Бондаренко Тетяна Олександрівна магістрант природничо-географрічного фракультету Сумський державний педагогічний університет імені А. С. Макаренка НАУКОВИЙ КЕРІВНИК:

Бабенко Олена Михайлівна канд. пед. наук , доцент, доцент кафедри хімії та методики навчання хімії Сумський державний педагогічний університет імені А. С. Макаренка УКРӒ̈HA

Суттєві реформи середньої освіти, а також відмінності у цінностях поколінь вимагають нових підходів до організації навчального процесу, зокрема, до проведення уроку. Дослідження проблеми сучасного уроку як з дидактичного, так і методичного поглядів дозволяють зрозуміти, що такий урок $\epsilon$ демократичним і проводиться не для учнів, а разом з ними, на такому уроці школярі навчаються здобувати знання, а не отримувати готові.

3 погляду «Теорії поколінь» цінності сучасних вчителів та учнів суттєво відрізняються, і тому зрозуміло, що умови традиційного навчання з вимогами фундаментальних системних знань із предметів та методами суб'єктоб'єктного репродуктивного навчання не $є$ ефрективними для порозуміння тих, хто навчається, із тими, хто навчає[1]. Необхідно шукати нові підходи та технології оптимізації навчання.

Як один із шляхів пропонуємо застосування скрайб презентацій для організації навчально - пізнавальної діяльності школярів із хімії. Останнім часом скрайбінг став інноваційним прийомом аудіовізуальної підтримки навчання. Відомі нам презентації, які створюють в MO PowerPoint, вже давно присутні на уроках вчителів, але вони $€$ досить статичними, часто не викликають емоційного захоплення учнів, тому зацікавити ними майже неможливо. В той час, як скрайб презентація є чудовим варіантом для того, 
щоб привернути увагу учнів, доступно та легко пояснювати складний матеріал, а також розставити головні акценти у навчальному матеріалі [2].

Нами було розроблено мультимедійну бібліотеку відео презентацій для організації навчального процесу з хімії учнів 9 класу під час вивчення теми «Розчини» з використанням онлайн-сервісу «Рow Toon».

До початку роботи нами було створено обліковий запис в онлайн сервісі Pow Toon, а також спеціальний ютуб канал для створених відео презентацій, адже ютуб на сьогоднішній день $є$ найбільш популярним сервісом для перегляду відео, тому для учнів немає ніяких складнощів з доступом до скрайб-презентацій.

Кожен учень отримав посилання на цей канал та підписався на оновлення, для того щоб отримувати сповіщення, коли завантажується нове відео. На першому ж уроці школярі отримали детальне пояснення та інструктаж щодо призначення цих презентацій та особливостей роботи з ними.

Метою нашого дослідження стало упровадження в навчальний процес 3 хімії скрайб презентацій, що, на нашу думку, має призвести до покращення рівня навчальних досягнень, умінь та компетентностей учнів.

Учні використовували розроблені скрайб презентації під час виконання домашніх завдань та при підготовці до контрольних робіт. Аналіз тематичної контрольної роботи з теми «Розчини» дозволив встановити, що середній бал оцінок учнів експериментального класу зріс майже на 7\%, тоді як середній бал оцінок учнів контрольного класу, навпаки, дещо знизився. Очевидно, що учні експериментального класу мали змогу краще розібратись із навчальним матеріалом за допомогою розроблених нами скрайб презентацій. На нашу думку, можливість постійного доступу до навчальних відео під час підготовки домашнього завдання, повторення пройденого матеріалу в класі, при підготовці до контрольної роботи і зумовило підвищення рівня навчальних досягнень школярів експериментального класу. Використання скрайб презентацій виявилось легким у розробці для вчителя, зручним у використанні для учнів i, з огляду на оцінки школярів, досить дієвим і ефективним.

Для того, щоб з'ясувати ставлення учнів до впровадження скрайб презентацій, нами було проведено анонімне анкетування школярів експериментального класу. Учні відразу відмітили, що раніше не використовували для навчання подібні презентації ні на уроках хімії, ні на інших навчальних предметах. На запитання «Чи сподобалося тобі використовувати скрайб презентації?» 96\% опитаних відповіли «так». Також $98 \%$ школярів указали, що хотіли б і надалі користуватися скрайб презентаціями, тому що для них це виявився найзручніший спосіб для підготовки домашніх завдань і вивчення нового матеріалу.

У подальшому плануємо дослідити ефрективність застосування скрайб презентацій під час вивчення навчального матеріалу у інших класах. А також запропонувати учням самим навчитись створювати по дібні навчальні відео.

\section{Список використаних джерел:}

1. Коростіль, Л. А. (2018). Покоління Z: пошук способів педагогічної взаємодії. Народна освіта (1), 82-84. Вилучено 3: https://www.narodnaosvita.kiev.ua/ ?page_id=5229 
2. Сорока, Т. В. (2015). Скрайбінг як сучасна форма візуалізації навчального матеріалу. Географрія, (16(284)). Вилучено 3: http://journal.osnova.com.ua/ article/51806

\title{
СПЕЦИФІКА ЗАСТОСУВАННЯ ІНТЕРАКТИВНИХ МЕТОДІВ НАВЧАННЯ
}

\author{
Зубченко Наталя Олексіївна \\ викладач загальнотехнічних дисциплін \\ Криворізький державний комерційно-економічний технікум \\ УКРӒ̈НA
}

Хороший викладач - це гнучкий, спостережливий та чуйний професіонал, що завжди намагається придумати, як зацікавити своїх студентів та захопити їх освітнім процесом. I це означає, що під час занять викладач використовує інтерактивні методи.

Інтерактивні методи викладання розроблені по одному й тому ж принципу: без практичного застосування теоретичних знань студенти в своїй більшості не здатні засвоювати матеріал у повному обсязі. Проте інтерактивне навчання $€$ корисним не тільки для студентів, але й для викладача. Для прикладу:

Вимірювання досягнень студентів. Викладач, який використовує інтерактивні методи навчання, здатний краще оцінити, як добре студенти опановують поданий матеріал[1].

Гнучкість у викладанні. Застосування методів, що включають повноцінну двосторонню комунікацію, дозволяє оперативно коригувати процес навчання, навантаження та підходи.

Практика - це шлях до досконалості. Інтерактивне навчання покращує загальну ефективність освітнього процесу.

Мотивація студентів . Двосторонні методи навчання підвищують активність студентів. Чим більше їх бере участь у процесі, тим веселіше йде навчання [2].

Під час стандартних занять-лекцій студенти часто втрачають інтерес до навчання, але інтерактивні методики створюють атмосферу уваги та зацікавленості. Вони просто роблять заняття більш цікавими, захоплюючими, веселими. Як ви знаєте, лекції - це ще не навчання студентів, а прослуховування лекцій - це ще не вивчення предмету [2].

Міжнародний центр освіти ARMA пропонує ряд принципів, що дозволяють виразити головні особливості інтерактивних методів навчання:

- Заохочувати активність студентів.

- Використовувати питання, що стимулюють спілкування, дискусії та використання практичних навичок.

- Використовувати прийоми, що наштовхують студентів на правильні відповіді, а також утримують увагу.

- Підтримувати робочу атмосферу.

- Включатися в роботу на одному рівні з студентами [3].

Отже, суть інтерактивного навчання полягає в тому, що освітній процес організований таким чином, що практично всі студенти беруть участь у процесі 
пізнання, вони мають змогу розуміти і рефлектувати з приводу того, що вони знають і думають. Інтерактивне навчання - це спеціальна фрорма організації пізнавальної діяльності, яка має конкретну, передбачувану мету - створити комфортні умови навчання, за яких кожен студент відчуває свою успішність, інтелектуальну спроможність.

\section{Список використаних джерел:}

1. Пометун, О., Пироженко, Л. (укл.) (2002). Інтерактивні технології навчання: теорія, практика, досвід роботи. Київ: А.П.Н.

2. Карпук, В., Чемерис, А. \& Шевчук, П. (2005) Курси дистанційного навчання. Львів: ЛРІДУ НАДУ.

3. Панина, Т., Вавилова, Л. (2008) Современные способы активизации обучения.Москва: Издательский центр «Академия».

\section{ТОЛЕРАНТНІСТЬ ЯК ПРОФЕСІЙНО-ВАЖЛИВА ЯКІСТЬ ПЕДАГОГА ІНКЛЮЗИВНОї ОСВІТИ}

Фархадова Есміра Шарабаддін кизи

здобувач вищої освіти фракультету дошкільної і корекційної освіти та історії, Комунальний заклад “Харківська гуманітарно-педагогічна академія»

Харківської обласної ради

НАУКОВИЙ КЕРІВНИК:

Єфименко Людмила Миколаївна

викладач кафедри теорії та методики дошкільної освіти Комунальний заклад “Харківська гуманітарно-педагогічна академія»

Харківської обласної ради

УКРӒ̈НA

Актуальність даної теми полягає у тому, що широке впровадження ідеї інклюзивної освіти ставить перед суспільством багато нових непростих завдань, у тому числі в процесі особистісної та професійної підготовки педагогів. На думку С. В. Альохіна, «первинною і найважливішою сходинкою підготовки системи освіти до реалізації процесу інклюзії є етап психологічних та ціннісних змін фрахівців і рівня їх професійних компетенцій» [1].

Однією з найважливіших цінностей сучасного суспільства $є$ толерантність, і тому, одним з пріоритетних напрямків роботи на даному етапі, на наш погляд, має стати формування установок толерантної свідомості й відносин у педагогів до дітей з особливостями психофізичного розвитку (ОПФР). Незважаючи на те, що інклюзивна освіта здійснюється з метою забезпечення рівних можливостей в отриманні освіти дітьми з різними освітніми потребами.

У нашій країні, як і в усьому світі, з різних причин зростає кількість дітей із відхиленнями у розвитку. Останнім часом міжнародна спільнота запропонувала використовувати для дітей із психофізичними порушеннями 
термін «діти з особливими освітніми потребами (ООП)», який стосується однаковою мірою як інвалідності у важкій формі, так і середніх за ступенями порушень [2].

Варто підкреслити, що інклюзивна освіта без толерантного ставлення членів суспільства, i, в першу чергу, самих педагогів як «провідників і реалізаторів ідеї інклюзивної освіти», відбутися не може. На думку, А. М. Змушко, толерантне ставлення $є$ однією з обов'язкових умов успішності інтеграції та інклюзії, а саме, прийняття людини такою, якою вона є, розуміння цінності для суспільства кожної особистості [3], кінцевою метою якої $є$ формування інклюзивного суспільства, в якому “особливості кожного його члена розглядаються як потенціал для розвитку, апріорна цінність, що надає суспільству різноманіття і сприяє його досконалості» [4].

Педагог із розвиненою педагогічною толерантністю має високі загальні розумові здібності, відрізняється зрілістю суджень, йому притаманна емоційна стабільність. Завдяки цим рисам педагог легко адаптується до взаємодії 3 різними суб'єктами професійної діяльності. Важливим моментом, що визначає сутність педагогічної толерантності, $є$ те, що вона формується й розвивається за певних соціальних умов і завдяки власним зусиллям особистості.

Необхідно зазначити, що педагогічна толерантність виявляється в «усвідомленні себе гуманною особистістю, у здатності керувати своїми емоційними та вольовими проявами в проблемних ситуаціях суб'єкт-суб'єктної взаємодії.

Толерантність має першорядне значення в роботі педагога, і саме у цьому, на жаль, відчувається досить істотний дефіцит поваги й терпимості. Розуміння толерантності як поваги та визнання рівності, відмови від домінування i насильства, визнання багатовимірності людської культури, норм, вірувань, відмова від зведення цього різноманіття до однаковості або до переваги однієї точки зору має бути основою професійної діяльності педагога.

Варто відзначити, що досить рідко педагогічна громадськість використовує дефініцію "толерантність», яку також розглядає як частину педагогічної культури, педагогічної компетенції, «важливий засіб профрілактики виникнення професійних деструкцій» [5]. Ухвалення особистості кожної дитини, далеко не завжди досягається в масовому закладі освіти, який традиційно тяжіє до «винесення оціночних суджень-вироків», «навішування ярликів», ієрархічності взаємин (тобто поділу «на хороших-поганих» і «особистісно симпатичних та несимпатичних» педагогу), що свідчить про відсутність толерантності та емпатії у педагогічній діяльності. Визнання або невизнання принципу прийняття дитини з особливостями розвитку - це показник моральної та психологічної готовності педагогів до роботи в інклюзивну освітньому просторі [4].

Слід також зазначити, що найбільш «прийнятої» категорією дітей з різними порушеннями розвитку як для педагогів з високим рівнем толерантності, так $\mathrm{i}$ з низьким $є$ діти з сенсорними й мовними порушеннями. Найбільш вразлива категорія - діти з інтелектуальною недостатністю, що багато в чому, на наш погляд, пояснюється наявністю стереотипів по відношенню до людей 3 інтелектуальною недостатністю, а також пріоритетом парадигми сучасної освіти перед соціальної, що часто неприпустимо при навчанні і вихованні дітей 
з інтелектуальними порушеннями. Абсолютна більшість педагогів вказує на необхідність отримання додаткових спеціальних знань про особливості розвитку різних категорій дітей з ООП, формування навичок надання підтримки, запобігання конфрліктам.

Висновки. Таким чином, аналіз психолого-педагогічної літератури, дозволив нам зробити наступні висновки. Толерантність $€$ професійно важливою якістю педагога-профресіонала інклюзивної освіти, що дозволяє йому не тільки ефективно здійснювати освітні завдання, але і долати несприятливі фактори впливу. Більш успішними в реалізації практики інклюзивної освіти, на наш погляд, будуть ті педагоги, які демонструють високий рівень толерантності, терпимості, прийняття інших та відкритість. Відтак, формування толерантних установок у майбутніх педагогів до дітей 3 ООП має стати одним з пріоритетних напрямків вищої професійної освіти.

\section{Список використаних джерел:}

1. Алехина, С.В. (2011) Готовность педагогов как основной фактор успешности инклюзивного процесса в образовании. Психологическая наука и образование, 83-92.

3. Клименко, І. О. (2014) Питання конфіденційності та толерантне ставлення до дітей 3 особливими освітніми потребами. Вилучено 3 : http://www.garmoniya.mk.ua/articles/pytannyakonfidenciynosti-ta-tolerantne-stavlennya-do-ditey-z-osoblyvymy-osvitnimy.

4. Хитрюк, В.В. (2014) Инклюзивное образование глазами педагога: «надо», «хочу», «могу». Весн. МДУ им. А.А. Куляшова, (43), 57-64.

5. Змушко, А.М. (2013) Від інтегрованого навчання - до інклюзивної освіти: ключові проблеми та завдання. Народна освіта, (1), 18-23.

6. Молчанова, А. О. (2013) Толерантність як ціннісна основа професійної діяльності педагога, Київ, 150.

\section{ТРАДИЦІЙНІ ФОРМИ НАВЧАННЯ ГОНЧАРСТВУ В ПІВНІЧНО-СХІДНІЙ УКРАЇНІ XIX - ПОЧАТКУ XX СТОЛІТТЯ}

Гулей Ольга Володимирівна заслужений майстер народної творчості України, старший викладач кафедри образотворчого мистецтва, музикознавства та культурології Сумський державний педагогічний університет імені А. С. Макаренка УКРАЇНА

Гончарство - один з найдавніших проявів матеріальної та духовної культури українців. Гончарні вироби традиційних культурно-освітніх осередків Північно-Східної України другої половини XIX - початку XX століття за функціональним призначенням поділяються на: посуд, обладнання житла, садово-паркові та архітектурні деталі, культові предмети, прикраси, іграшки тощо. Варто зазначити, що гончарні народні вироби майстрів досліджуваного регіону України могли бути оздоблені розписом, елементами якого $\epsilon$ стилізовані рослинні мотиви (соняшники, мальви, тюльпани, грона винограду, 
кетяги калини), а також зооморфнні (птахи, звірі, риби) [1]. Створення високохудожніх гончарних виробів вимагало наполегливої багаторічної підготовки майбутнього майстра-ремісника. Особливістю навчання народному промислу у сім'ї гончара досліджуваного періоду $є$ той фракт, що уся родина займалася гончарюванням [2]. Діти допомагали дорослим в роботі наслідуючи практичні навички батьків. Секрети майстерності передавалися із роду в рід. Праця гончара охоплювала різні етапи роботи: від підготовки гончарної глини до виготовлення виробу на гончарному крузі, сушіння й випалювання в печі, реалізації на ярмарках [3]. Від кінця XIX століття, у зв'язку зі збільшенням кількості гончарів, загостренням конкуренції між ними та ускладненням процесу збуту, все більше гончарів віддавали вироби оптом приїжджим скупникам, або ж «горшковозам» зі свого чи із сусідніх сіл. При цьому, як зазначає В. Міщанин, такі далекі поїздки на ярмарки могли дозволити собі лише заможні гончарі за умови, що вони виготовляли якісний, красивий, конкурентно спроможний посуд [4]. Слід зауважити на тому, що з розвитком мануфрактурного виробництва, починаючи від 80-х років XIX століття обізнані майстри почали брати обмежену кількість учнів «у науку» [5]. Доцільно вказати, що учнівство у ремісника-гончара відбувалося у формі: спостереження за роботою майстра, наслідування технологічних прийомів, засвоєння настанов і практичних порад гончара. Наразі, нерідко праця учнів використовувались для ведення господарчих робіт майстра-наставника, що трактувалося як платня за «науку». Відтак, навчання народному художньому гончарному ремеслу в Північно-Східній Україні XIX - початку XX століття відбувалося традиційними шляхами позаінституційної освіти окресленого періоду: по-перше, у формі сімейного навчання й виховання; по-друге, у формі праці у провідних майстрів.

\section{Список використаних джерел:}

1. Чирка, І. (2008). Національне виховання і національний музей гончарства. Берегиня, (2), $67-69$.

2. Варивончик, А. В. (2015). Кераміка в контексті художніх промислів України. Вісник КНУКіМ. Серія: Мистеитвознавство, (33), 31-38.

3. Мотиль, Р. (2014). Виробництво неполив'яної кераміки. Народознавчі зошити, 5 (119), 9981011.

4. Міщанин, В. (2004). Збут виробів гончарями малих осередків Опішненського гончарного регіону наприкінці XIX - y першій половині XX століття. Керамологічний журнал: Етнограсрія гончарства, 1 (11), 110-118.

5. Овчаренко, Л. М. (2008). Проблеми гончарної освіти на території Лівобережної України наприкінці XIX - на початку XX століття на прикладі діяльності Поставмуцької земської гончарної навчальної майстерні. Історична пам'ять, (1), 88-97. 
DOI 10.36074/13.12.2019.v3.09

\title{
ФОРМУВАННЯ ІНДИВІДУАЛЬНОГО СТИЛЮ ПРОФЕСІЙНОЇ ДІЯЛЬНОСТІ МАЙБУТНІХ МЕНЕДЖЕРІВ СОЦІОКУЛЬТУРНОЇ ДІЯЛЬНОСТІ 3 ВИКОРИСТАННЯМ TPEHIHГУ
}

\begin{abstract}
Сорока Ольга Вікторівна
доктор педагогічних наук, доцент, професор кафедри соціальної педагогіки і соціальної роботи

Тернопільський національний педагогічний університет імені Володимира Гнатюка

Калаур Світлана Миколаївна доктор педагогічних наук, доцент, доцент кафедри соціальної педагогіки і соціальної роботи

Тернопільський національний педагогічний університет імені Володимира Гнатюка УКРАЇНА
\end{abstract}

Активний розвиток суспільства та поява нових можливостей для розкриття професійного потенціалу конкурентоспроможних менеджерів соціокультурної діяльності вимагають розгляду питання щодо саморозвитку, самовиховання та формування індивідуального стилю професійної діяльності, що сприятиме підвищенню їх професійної компетентності, забезпечить реалізацію активної позиції на ринку праці, покращить психоемоційний стан та підвищить мотивацію до праці. Сучасне суспільство потребує менеджерів соціокультурної діяльності, які були б спроможні до самовизначення й саморозвитку в складних управлінських ситуаціях, чітко визначали свої дії, були відкритими до нового досвіду використання нововведень та психологічно готовими до виконання професійної діяльності.

Оскільки професією «менеджер соціокультурної діяльності» і профресійною майстерністю можна опанувати лише на індивідуально-особистісному рівні, актуальною $є$ проблема оволодіння менеджером соціокультурної діяльності індивідуальним стилем професійної діяльності, що забезпечує реалізацію його суб'єктної, «авторської» позиції. Зазначимо, що індивідуальний стиль професійної діяльності - одна з найважливіших характеристик, якостей та рівнів розвитку особистості, що проявляється в межах професійної діяльності.

Сьогодні науковці досліджують різні аспекти індивідуального стилю, зокрема, це питання його формування, корекції та розвитку. Теоретикометодологічні основи проблематики когнітивного і творчого стилів представлено в наукових доробках В. Дружиніна, І. Зимньої, Н. Кузьміної та інші; індивідуальний стиль професійної діяльності досліджували Ж. Ковалів, О. Шпортун та інші.

Нажаль, до цього часу між науковцями не існує чіткої єдності поглядів щодо розуміння поняття «індивідуальний стиль професійної діяльності». У науководовідкових джерелах «стиль» розглядають як:

- «відносно стійку сукупність характеристик і повторюваних рис людини, які виявляються у її мисленні, поведінці, спілкуванні. Стиль виробляється під час 
теоретичного й практичного освоєння людиною навколишньої дійсності i передбачає, з одного боку, гнучке пристосування до неї, з другого - ї̈ революційну зміну. У стилі проявляються здібності, характерологічні риси та звички особистості» [3];

- характерну для даного індивіда систему навичок, методів, прийомів, способів вирішення завдань тієї чи іншої діяльності, що забезпечує більшменш успішне ії виконання. Комплекс індивідуальних особливостей людини може частково задовольняти вимоги певного виду діяльності, тому людина свідомо чи стихійно, мобілізуючи свої цінні якості, компенсує ті, які перешкоджають досягненню успіху. У результаті створюється індивідуальний стиль діяльності - неповторний варіант типових для даної людини прийомів роботи в типових умовах» [8].

Спробуємо уточнити досліджуване поняття з урахуванням специфіки професійної діяльності менеджера соціокультурної діяльності. Нам імпонує трактування індивідуального стилю професійної діяльності С. Колосової, яка розуміє його як «сукупність професійно-педагогічних знань, умінь та навичок, індивідуальних властивостей, психолого-педагогічних здібностей, що обумовлюють індивідуальну своєрідність застосування методів та прийомів у процесі професійної підготовки та навчально-виховної діяльності відповідно до фраху» [6]. Ж. Ковалів визначає індивідуальний стиль професійної діяльності як «своєрідний самопрояв його особистості в педагогічній діяльності через усталену систему засобів та прийомів, що утворюють особистісну систему дій» [5]. Г. Берулава характеризує індивідуальний стиль особистості в ії̈ потенційному розвитку, творчості та діяльності. «Стиль індивідуальності - це інтегральна характеристика функціональної системи індивідуальних властивостей, що виявляються в тих складових людської активності, що не контролюються свідомістю і спрямовані на задоволення базових потреб суб'єкта» [1].

Узагальнений аналіз психолого-педагогічної літератури дав нам змогу визначити поняття «індивідуальний стиль професійної діяльності менеджера соціокультурної діяльності» як сукупність знань, умінь і навичок, індивідуальних властивостей, здібностей, характеристик, що обумовлюють індивідуальну своєрідність використання форм, методів, технологій та прийомів у процесі професійної діяльності.

Формування індивідуального стилю професійної діяльності передбачає три напрями. Перший напрям спрямований на теоретичну психолого-педагогічну підготовку менеджерів соціокультурної діяльності, що забезпечується проведенням інформаційних занять, ознайомлення з теоретичними основами професійної діяльності менеджерів соціокультурної діяльності, чинниками розвитку та методами формування індивідуального стилю професійної діяльності. Другий - являє собою тренінг, спрямований на формування та розвиток означеного феномену. Третій напрям направлений на комунікативну підготовку менеджерів соціокультурної діяльності.

Вважаємо, другий напрям є найбільш ефективним у професійній підготовці менеджерів соціокультурної діяльності, пояснюючи це тим, що «тренінг - це нетрадиційна форма організації навчання, спосіб організації активності його учасників з метою здобуття спеціальних знань, вироблення на цій основі умінь 
і навичок, необхідних для профресійної діяльності» [9]. Окрім цього ми переконані, що «тренінг (англ. training) - це запланований процес модифікації (зміни) відношення, знання чи поведінкових навичок того, хто навчається, через набуття навчального досвіду з тим, щоб досягти ефективного виконання в одному виді діяльності, або в певній галузі» [4].

Підтримуємо зарубіжних учених в тому, що тренінг може досягнути поставлених цілей, якщо це дійсно інтерактивне навчання, що передбачає спеціальні вправи для створення внутрішніх переживань, відпрацювання навичок і адаптацію загальних закономірностей до реальної ситуації учасників процесу навчання [2].

Для формування індивідуального стилю профеесійної діяльності менеджерів соціокультурної діяльності ми розробили тренінг, що містив п'ять занять: 1. Самопрезентація у професійній діяльності. 2. Фактори, що впливають на стиль професійної діяльності менеджерів. 3. Механізм формування індивідуального стилю професійної діяльності менеджерів. 4. Зв'язок стилю професійної діяльності з іміджем. 5. Визначення стратегії професійної поведінки.

При складанні тренінгової програми ми дотримувались таких вимог: чітке формулювання цілей та завдань тренінгу; підбір методик і технік; підготовка матеріалів та обладнання; визначення часу тривалості кожної вправи; оцінка ефективності програми.

У розробленій програмі тренінгу ми використовували різні форми, методи і прийоми роботи: ділові ігри, групові дискусії, створення команди, мозковий штурм, незакінчені речення, творчі завдання, психогімнастику, конкурси, елементи арт-терапії тощо.

Відзначимо, тренінг відбуватиметься ефективніше, якщо матиме такі складові: 1) привітання - знайомство учасників; 2) вироблення правил роботи в групі; 3) оголошення теми тренінгового заняття; 4) розминку; 5) основну частину: вступне слово тренера (міні-лекцію, повідомлення, інструкції тощо), різноманітні вправи з подальшим обговоренням і рефлексією; 6) підбиття підсумків роботи - резюме ведучого; 7) прощання [10].

При проведенні тренінгової програми необхідно дотримуватися принципів, сформульованих А. Осиповою:

1) принцип творчої позиції учасників: у процесі занять створюють ситуації, в яких учасники мають проявляти самостійність у розв'язанні завдань та прийняття конструктивних рішень, відкривати для себе нові виміри проблемних ситуацій;

2) принцип активності: члени групи залучаються до ділових ігор, дискусій, виконують тематичні вправи;

3) принцип партнерської взаємодії: характеризується рівністю позицій учасників, визнанням цінності особистості іншої людини, прагненням до співпереживання та розуміння інтересів співрозмовника;

4) принцип об'єктивізації поведінки передбачає наявність зворотного зв'язку від інших учасників групи й від тренера, стосовно власної поведінки;

5) принцип безумовного прийняття учасників полягає у безоцінювальному сприйнятті учасниками одне одного [7]. 
Окрім того, ми орієнтувалися також на принципи системності, комплексності, індивідуального підходу й врахування емоційної складності матеріалу.

По завершенню тренінгу кожний студент має представити власну «Програму індивідуального стилю», яка передбачає практичні шляхи реалізації отриманих знань і вдосконалення методів і прийомів розвитку індивідуального стилю професійної діяльності. Розроблений тренінг був апробований у Тернопільському національному педагогічному університеті імені Володимира Гнатюка як доповнення до дисциплін «Вступ до спеціальності», «Менеджмент соціокультурної діяльності», «Тренінгові технології», які входять до циклу обов'язкових професійно зорієнтованих дисциплін у освітній програмі «Менеджмент соціокультурної діяльності».

\section{Список використаних джерел:}

1. Берулава, Г. А. (2001). Стиль индивидуальности: теория и практика. Учебное пособие. М.

2. Браткин, А. \& Скоробогатова, И. (2006). Чемоданчик тренера. 10 продаваемых тренингов. М.: Генезис.

3. Гончаренко, С. У. (1997). Український педагогічний словник. К.: Либідь.

4. Калаур, С. М. (2017). Використання тренінгових технологій під час формування готовності майбутніх фахівців соціальної сфери до розв'язання конфлліктів у професійній діяльності. Просресійна освіта: методологія, теорія та технології: зб. наук. праць, (5/1), 86-98.

5. Ковалів, Ж. В. (2005). Формування індивідуального стилю профресійної діяльності майбутніх учителів гуманітарних дисциплін (дис.... канд. пед. наук). Одеса.

6. Колосова, С.В. (2017). характеристика індивідуальних стилів професійної діяльності майбутнього вихователя дітей дошкільного віку. Духовність особистості: методологія, теорія і практика, 1 (76), 75-83.

7. Осипова, А. А. (2000). Введение в теорию психокоррекции. М.: Московский психологосоциальный институт; Воронеж: Издательство НПО Модэк.

8. Давыдова, В. В., Запорожца, А. В. \& Ломова, Б. Ф. (1983). Психологический словарь. М.: Педагогика.

9. Сорока, О. В. (2016). Теоретичні і методичні засади підготовки майбутніх учителів початкової школи до використання арт-терапевтичних технологій (дис. ... д-ра пед. наук). Тернопіль.

10. Сорока, О. В. (2017). Формування управлінської компетентності майбутніх фрахівців соціальної сфери засобами тренінгу. Науковий вісник Ізмаїльського державного гуманітарного університету: збірник наукових праць. Серія «Педагогічні науки». Ізмаїл: РВВ ІДГУ. Вип. 36, 241-246. 


\title{
SECTION XI. PHILOLOGY
}

\section{MEDIA LITERACY IN THE EDUCATIONAL PROCESS OF THE $21^{\text {ST }}$ CENTURY}

\author{
RESEARCH GROUP: \\ Nataliia Maslavchuk \\ Lecturer \\ Vasyl' Stus Donetsk National University \\ Maria Hnenna \\ Lecturer \\ Vasyl' Stus Donetsk National University \\ Leonila Mazur \\ Senior Lecturer \\ Vasyl' Stus Donetsk National University \\ UKRAINE
}

Introduction. The economical, technological and scientific development of the world in the $21^{\text {st }}$ century has evoked opening media space for everyone and widening its spheres of influence. Consequently, we are surrounded with the information everywhere, namely TV, street adverts, billboards, flyers, social nets, Internet, etc. We have 24/7 access to the Internet via which we consume all kinds of information including verified, credible, and discolored one.

Actuality. In the era when necessary information is achieved in one click, the issue of its credibility is becoming of high importance. Moreover, the usage of the gadgets, which assist consumption of news, is drastically increasing, especially among young population. So, media literacy education is becoming urgent in the teaching process.

Review of resources. Since the issue of media literacy is relatively new trend of the modern society, there are quite substantial researches on this aspect. Thus, Daniel Ciurel, Monica Bulger and Patrick Davison, Tibor Koltay, Alexander Fedorov, Elizabeth Thoman, Tessa Jolls and others have been working in this field. Among current Ukrainian ambassadors Oksana Torubara and Tetiana Tarenkova should be mentioned.

Results of the research. What is Media Literacy? There is a wide range of definitions of it and the fullest one is "Media literacy is the ability to access, analyse, evaluate, create and act using all forms of communication" [6]. These skills are very important in the $21^{\text {st }}$ century, formation of which starts at school. The process of learning media literacy is called media education. Being included into curriculum it encourages critical understanding of the nature, techniques and impacts of media messages and productions by a student. 
So, the reasons to integrate media literacy into the educational process might be the following:

1. It makes a user question, evaluate, understand and appreciate multimedia culture;

2. It assists integration of the subjects such as History, Health, the Creative Arts, etc;

3. Media education is based on student-centred learning;

4. The process involves the world a child lives in (music, television, video games, the Internet and ads) in the connection with their attitudes, lifestyle choices and self-image;

5. Media education develops creativity that is increasingly demanded at the working places;

6. It engages young people in issues like politics, society life making them active citizens and potential contributors to public development;

7. The study of media helps youth understand how media portrayals can influence on one's view on different groups in society;

8. Media literacy also teaches youngsters to distinguish between reality and fantasy as they compare concepts shown in the media to the concepts in real life;

9. It assists developing critical thinking skills [4].

To develop our critical thinking and to be aware of what we hear, read or see, researchers recommend to remember some key concept of media literacy:

a) All media products are created by individuals who consciously or unconsciously choose what to include and how to present the product.

b) Different audiences interpret the media product according to individual factors such as age, gender, race and social status.

c) Media has its profitable implication.

d) Media tends to appeal to values, power and authority and it leads to biases that influence on what we think and believe.

e) Aesthetic form of media includes the technical, commercial and storytelling demand, for instance, the interactive nature of video games leads to different forms of storytelling that are found in film and TV [4].

There are some ways to achieve the aim of media literacy at the lessons of English:

1. Recognizing Fake News: teach students to check the date and author credentials, gauge the tone and language, and identify biases.

2. Using Multiple Sources: teach to check other sources for the same story, to analyze the information given there and make the picture fuller and more accurate.

3. Gauging Tone and Language: since we are prone to believe what is said or written in flowery or academic language, students must be taught to be good writers themselves and understand that clear communication is their goal.

4. Questioning Numbers and Figures: it is often required to evaluate numbers. For example, if some statistics is given, we have to process the details to see how valid the survey is analyzing the actual number of those who were questioned.

5. Understanding Images and the Brain: while reading images immediate emotional level on which we react and the way the product is meant to influence us should be considered. 
6. Developing Multimedia Skills: today's students need to be well versed in modern different tools of $21^{\text {st }}$ century technology.

7. Recognizing Bias: teach students to recognize both which channels might emphasize certain kinds of contexts or angles and their own biases, which can influence their perceptions of the media as well.

8. Shaping the Media Ourselves: people's opinions are diverse which should help shape the media.

9. Curating Information: teach students how to effectively filter, select, organize, save, and use information gathered from media sources.

10. Becoming Responsible Creators: teach students to be responsible creators of media [1].

Conclusion. Compilation of all the works on media has helped conclude that the issue of media literacy is becoming popular nowadays since people in the $21^{\text {st }}$ century, especially younger generations, are surrounded with lots of information and are influenced by it. It is significant to include media literacy into educational process because it creates fuller picture of the world. One of the efficient features of media literacy is development of critical thinking that makes a student be aware of his or her role in the society. Through the ways of teaching media literacy young people will be taught to recognize fake news, use multiple sources, gauge tone and language, question numbers and figures, understand images, recognize bias, they will develop multimedia skills to become responsible creators.

\section{References:}

1. 10 Creative Ways to Teach Media Literacy. Retrieved from https://www.canva.com/learn/10creative-methods-to-teach-media-literacy/.

2. Alexander Fedorov. (2017). Media Liteacy Education. Moscow: ICO "Information for all. Retrieved from https://www.ifap.ru/library/book564.pdf.

3. Daniel Ciurel. (2016). Media Literacy: Concepts, Approaches and Competencies. Proffessional Communication and Translation Studies, 13-20. Retrieved from https://www.researchgate.net/publication/319416173_MEDIA_LITERACY_CONCEPTS_APPR OACHES_AND_COMPETENCIES

4. Media Literacy Fundamentals. Retrieved from http://mediasmarts.ca/digital-medialiteracy/general-information/digital-media-literacy-fundamentals/media-literacy-fundamentals.

5. Monica Bulger \& Patrick Davison. (2018). The Promises, Challenges, and Futures of Media Literacy. Data\&Society. Retrieved from https://datasociety.net/pubs/oh/DataAndSociety_Media_Literacy_2018.pdf.

6. National Association for Media Literacy Education. Retrieved from https://namle.net/publications/media-literacy-definitions/. 


\begin{abstract}
ВИКОРИСТАННЯ ЧЕН'ЮЙ ДЛЯ ХАРАКТЕРИСТИКИ ПРИНЦИПУ ЗАБЕЗПЕЧЕННЯ ГАРМОНІЙНОГО ТА ВСЕОСЯЖНОГО (和谐包容) РОЗВИТКУ (坚持和谐包容) B КИТАЙСЬКІЙ ІНІЦІАТИВІ «ОДИН ПОЯС - ОДИН ШЛЯХ»

$$
\text { (一带一路) }
$$
\end{abstract}

Чернявська Олена Валеріївна

Студентка ІУ курсу

Д3 «Луганський національний університет імені Тараса Шевченка»

Чернявська Олександра Дмитрівна

Студентка III курсу

ДЗ «Луганський національний університет імені Тараса Шевченка»

НАУКОВИЙ КЕРІВНИК:

Федічева Наталія Володимирівна

кандидат педагогічних наук, завідувач кафедри східних мов Д3 «Луганський національний університет імені Тараса Шевченка»

УКРӒ̈HA

Чен'юй (成语) - це стійке фразеологічне сполучення, найчастіше чотирьохслівне, побудоване за нормами класичної китайської мови веньянь (文言文), семантично єдине, 3 узагальнено переносним значенням. В офріційному китайському дискурсі, де фрормулюються основні напрямки в розвитку держави, виробляється або коригується політичний курс країни, підводяться підсумки діяльності партії, відзначаються успіхи і критикуються промахи, китайські лідери зазвичай вживають у мові чен'юй 3 метою привернути увагу аудиторії до певної події чи явища, нових цілей, цінностей, напрямів суспільного руху, нових поглядів на офріційну візію розвитку країни, надаючи їх визначенням усталеної форми у вигляді чен'юй.

Результати аналізу повного тексту плану дій щодо запропонованої Китаєм ініціативи "Один пояс, один шлях", виданого Національною комісією розвитку та реформ, Міністерством закордонних справ та Міністерством торгівлі КНР, 3 дозволу Державної ради, дозволило виділити чен'юі, що вживаються як для самої назви ініціативи і позначення ключових її напрямів, так і для організації структури тексту (таблиці 1-3).

Таблиця 1

Використання чен'юй для характеристики принципу забезпечення гармонійного та всеосяжного (和谐包容) розвитку (坚持和谐包容)

\begin{tabular}{|c|c|c|c|c|}
\hline № & $\begin{array}{c}\text { Назва } \\
\text { принципу }\end{array}$ & \multicolumn{1}{|c|}{ Складові } & $\begin{array}{c}\text { Офріційний переклад } \\
\text { англійською }\end{array}$ & $\begin{array}{c}\text { Авторський переклад } \\
\text { українською }\end{array}$ \\
\hline \multirow{3}{*}{1} & 求同存异 & $\begin{array}{l}\text { 同 - те сати, } \\
\text { 存- зберегти, } \\
\text { 异 - різні }\end{array}$ & $\begin{array}{c}\text { seeking common } \\
\text { ground while shelving } \\
\text { differences }\end{array}$ & $\begin{array}{c}\text { Шукайте спільної точки } \\
\text { зору, зберігаючи } \\
\text { відмінності }\end{array}$ \\
\hline
\end{tabular}




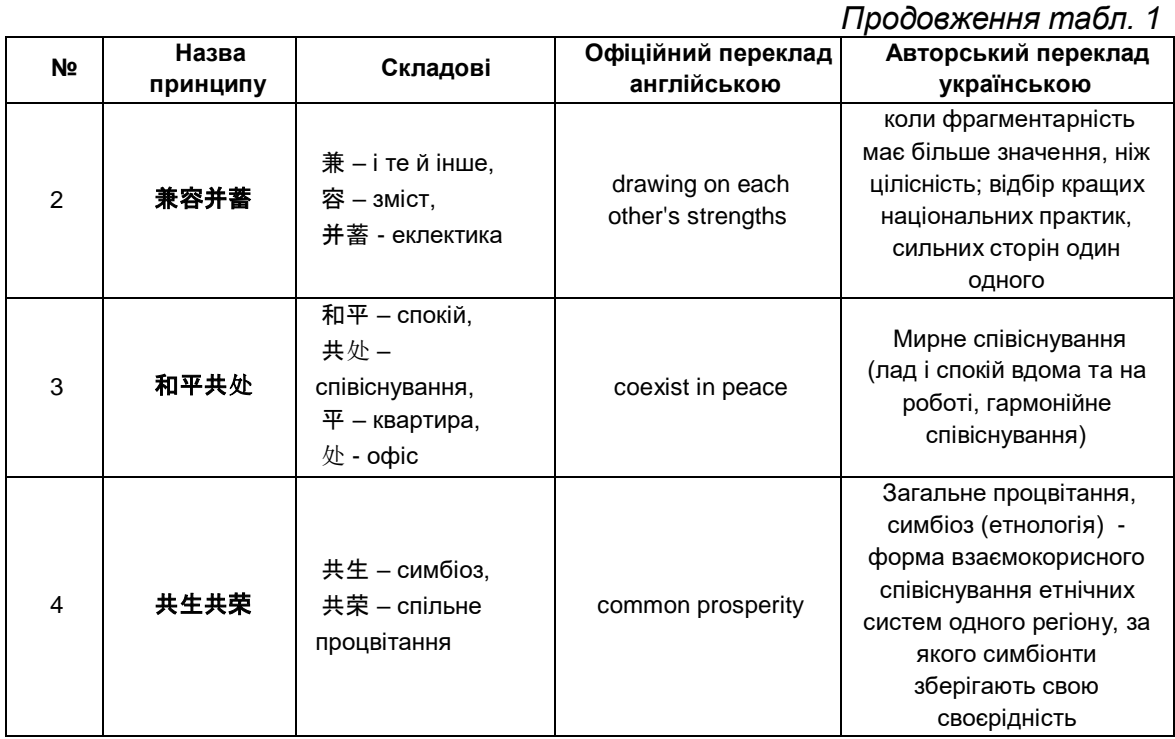

Таблиця 2

\section{Використання чен'юй для характеристики п'яти принципів мирного співіснування (守和平共处五项原则) відповідно до цілей і принципів статуту $\mathrm{OOH}$ (联合国宪章的宗旨和原则)}

\begin{tabular}{|c|c|c|c|c|}
\hline № & Назва принципу & Складові & $\begin{array}{c}\text { Офіційний переклад } \\
\text { англійською }\end{array}$ & $\begin{array}{c}\text { Авторський переклад } \\
\text { українською }\end{array}$ \\
\hline 1 & 互不侵犯 & $\begin{array}{l}\text { 互 - взаємне, } \\
\text { 不 - ні, не } \\
\text { (заперечення), } \\
\text { 侵犯 - порушувати, } \\
\text { 侵 - вторгатися, } \\
\text { 犯 - звернутись }\end{array}$ & $\begin{array}{c}\text { mutual } \\
\text { nonaggression }\end{array}$ & $\begin{array}{c}\text { Взаємний ненапад } \\
\text { (ненасильницький світ, } \\
\text { неагресія, політика } \\
\text { взаємного ненападу) }\end{array}$ \\
\hline 2 & 和平共处 & $\begin{array}{l}\text { 和平 - спокій, } \\
\text { 共处 - } \\
\text { співіснування, } \\
\text { 平 - квартира, } \\
\text { 处 - офріс }\end{array}$ & peaceful coexistence & $\begin{array}{l}\text { Мирне співіснування } \\
\text { (лад і спокій вдома та } \\
\text { на роботі, гармонійне } \\
\quad \text { співіснування) }\end{array}$ \\
\hline 3 & 平等互利 & $\begin{array}{l}\text { 平等 - рівний, } \\
\text { 互利 - взаємна } \\
\text { вигода, } \\
\text { 平 - квартира, } \\
\text { 等 - чекати, } \\
\text { 互 - взаємний, } \\
\text { 利 - прибуток }\end{array}$ & $\begin{array}{c}\text { equality and mutual } \\
\text { benefit }\end{array}$ & $\begin{array}{c}\text { Рівність і взаємна } \\
\text { вигода (працюйте на } \\
\text { своїх територіях, } \\
\text { співпрацюйте на } \\
\text { рівних і чекайте на } \\
\text { взаємний прибуток) }\end{array}$ \\
\hline
\end{tabular}


Використання чен'юй для позначення та характеристики принципу взаємної вигоди (互利共赢)

\begin{tabular}{|c|c|c|c|c|}
\hline № & Назва принципу & Складові & $\begin{array}{c}\text { Офріційний переклад } \\
\text { англійською }\end{array}$ & $\begin{array}{c}\text { Авторський переклад } \\
\text { українською }\end{array}$ \\
\hline 1 & 互不侵犯 & $\begin{array}{l}\text { 互 - взаємне, } \\
\text { 不 - ні, не } \\
\text { (заперечення), } \\
\text { 侵犯 - порушувати, } \\
\text { 侵 - вторгатися, } \\
\text { 犯 - звернутись }\end{array}$ & $\begin{array}{c}\text { mutual } \\
\text { nonaggression }\end{array}$ & $\begin{array}{c}\text { Взаємний ненапад } \\
\text { (ненасильницький світ, } \\
\text { неагресія, політика } \\
\text { взаємного ненападу) }\end{array}$ \\
\hline 2 & 和平共处 & $\begin{array}{l}\text { 和平 - спокій, } \\
\text { 共处 - } \\
\text { співіснування, } \\
\text { 平 - квартира, } \\
\text { 处 - офріс }\end{array}$ & peaceful coexistence & $\begin{array}{c}\text { Мирне співіснування } \\
\text { (лад і спокій вдома та } \\
\text { на роботі, гармонійне } \\
\text { співіснування) }\end{array}$ \\
\hline 3 & 平等互利 & $\begin{array}{l}\text { 平等 - рівний, } \\
\text { 互利 - взаємна } \\
\text { вигода, } \\
\text { 平 - квартира, } \\
\text { 等 - чекати, } \\
\text { 互 - взаємний, } \\
\text { 利 - прибуток }\end{array}$ & $\begin{array}{c}\text { equality and mutual } \\
\text { benefit }\end{array}$ & $\begin{array}{c}\text { Рівність і взаємна } \\
\text { вигода (працюйте на } \\
\text { своїх територіях, } \\
\text { співпрацюйте на } \\
\text { рівних і чекайте на } \\
\text { взаємний прибуток) }\end{array}$ \\
\hline
\end{tabular}

Наведені результати дослідження є авторською позицією і публікуються 3 метою відкритого обговорення.

\section{Список використаних джерел:}

1.“一带一路”规划（双语全文）/中国日报网。 Retrieved from http://language.chinadaily.com.cn/2015-03/30/content_19950951.htm.

2. 携手推进“一带一路”建设2017年5月14日，中国国家主席习近平在“一带一路”高峰 论坛上的主旨演讲(全文). (2007). Україна-Китай, 2(8), 2-4.

3. Сі Цзіньпін, Голова Китайської Народної Республіки. (2017). Побудуємо разом \Один пояс один шлях. Україна-Китай, 2(8), 5-10.

4. 赵冰冰.从贤能政治看中国政治话语表达. Чжао Бинбин. Обзор китайского политического дискурса политической элиты. Изъято из http://theory.people.com.cn/n/2014/0226/c143844-24466004.html. 


\section{ГРАМАТИЧНІ АСПЕКТИ ПЕРЕКЛАДУ МІЖНАРОДНОЇ ДОКУМЕНТАЦІї}

Вдовиченко Ольга Олександрівна
здобувач вищої освіти факультету лінгвістики та соціальних комунікацій
Національний авіаційний університет

УКРАÏHA

Переклад міжнародної документації вимагає відповідної компетенції та достатніх фонових знань, адже має безліч сталих виразів, визначень юридичної тематики, запозичень з інших мов, до прикладу з латинської та французької. Проте, переклад таких текстів має і певні особливості, зокрема граматичні. Візьмемо до уваги таку граматичну конструкцію як інфінітив. Існують різні способи його перекладу: за допомогою іменника у функції підмета, інфінітивної конструкції у функції обставини мети, неозначеної форми дієслова тощо [1]. Наведемо приклад з Загальної декларації прав людини $\mathrm{OOH}$ :

...the obligation of States under the Charter of the United Nations is to promote universal respect for [2]. - ...за статутом Організації Об'єднаних Націй держави зобов'язані заохочувати загальне поважання [3].

The State Parties to the present Covenant undertake to guarantee [2]. Держави, які беруть участь у цьому Пакті зобов'язуються гарантувати [3].

Варто звернути увагу на те, що у наведених вище прикладах інфінітив перекладається за допомогою неозначеної форми дієслова, що $є$ дуже поширеним для такого типу документів.

Слід зазначити, що достатньо поширеним є застосування перекладацької трансформації додавання, наприклад:

The State Parties recognize the right of everyone: a) to take part in cultural life; b) to enjoy the benefits of scientific progress and its applications; $c$ ) to benefit from the protection of the moral and material interests... [2]. - Держави визнають право кожної людини на: а) участь у культурному житті; б) користування результатами наукового прогресу та їх практичне застосування; с) користування захистом моральних і матеріальних інтересів...[3].

Застосування цієї трансформації має на меті введення в переклад лексичних елементів, що відсутні в оригіналі, з метою правильної передачі смислу речення (оригіналу), що перекладається, та/або дотримання мовленнєвих і мовних норм, що існують в культурі мови перекладу [1].

Розглянемо застосування дієприслівників та дієприкметників. В. І. Карабан стверджує, що дані конструкції перекладаються особовою або неозначеною формою дієслова-присудка у складі підрядного обставинного речення (яке приєднується сполучниками «коли», «якщо», «оскільки» та ін.), активним дієприкметником, прийменниково-іменниковим словосполученням, дієприслівником доконаного виду, дієприслівником тощо [1].

Considering the obligation of States under the Charter of the United Nations to promote universal respect for, and observance of, human rights and freedoms [2]. -Беручи до уваги, що за Статутом Організації Об'єднаних Націй держави 
зобов'язані заохочувати загальне поважання $i$ додержання прав $і$ свобод людини [3].

У наведеному вище прикладі маємо дієприкметник I, тобто дієприкметник активного стану і спостерігаємо, що дієприкметник під час перекладу перетворюється на дієприслівник. Розглянемо інший приклад:

Recognizing that the child, for the full and harmonious development of his or her personality, should grow up in a family environment, in an atmosphere of happiness, love and understanding [2]. - Визнаючи, що дитині для повного і гармонійного розвитку їі особи необхідно зростати в сімейному оточенні, атмосфері щастя, любові і розуміння [3].

Даний приклад підтверджує наведене вище твердження, що доводить, що такий спосіб перекладу має широке застосування у перекладі міжнародної документації.

Варта уваги і інверсія. У більшості випадків, якщо вона присутня в оригіналі, то залишається і при перекладі:

For the purpose of the results achieved by State Parties...there should be adopted a special document [2]. - Для розгляду результатів, досягнутих державами-учасницями... приймається спеціальний документ..[3].

У наведеному вище прикладі порядок слів не змінений, підмет стоїть після присудка, проте переклад звучить доволі органічно та природньо.

Формальний додаток it також доволі поширений у міжнародній документації. It служить для представлення наступного смислового додатка, який звичайно виражений або інфінітивним словосполученням, або підрядним з'ясувальним реченням. Оскільки в українській мові подібного синтаксичного явища немає, формальний додаток it не перекладається [1].

Whereas it is essential to promote the development of friendly relations between nations [2]. - Беручи до уваги, що необхідно сприяти розвиткові дружніх відносин між народами [3].

Звертаємо увагу на те, що у перекладі it опущене, що не робить переклад неповним чи неприроднім.

Таким чином, підбиваючи підсумки вище сказаного потрібно зазначити, що переклад міжнародної документації дійсно не є простим через свою специфіку. Тому, перекладач, перш за все, повинен мати широкий діапазон позафонових знань і не прагнути до дослівного перекладу, а навпаки дотримуватися принципу адекватності.

\section{Список використаних джерел:}

1. Карабан, В.І. (2018). Переклад англійської наукової і технічної літератури. В.: Нова Книга.

2. UN Convention on Human Rights. Вилучено із http://www.un.org/en/documents/udhr/

3. Загальна декларація прав людини ООН. Вилучено із http://zakon.rada.gov.ua/cgibin/laws/main.cgi?nreg=995_015 


\section{ДРАМА АБСУРДУ В НІМЕЦЬКОМОВНІЙ ДРАМАТУРГІЇ: ПРОБЛЕМИ ПОЕТИКИ ТА ПЕРЕКЛАДУ}

Тарасюк Валерія Вячеславівна

здобувач вищої освіти факультету іноземної філології Житомирський державний університет ім. Івана Франка

НАУКОВИЙ КЕРІВНИК:

Васильєв Є.М. доктор філологічних наук, доцент кафедри германської філології і зарубіжної літератури Житомирський державний університет ім. Івана Франка

УКРӒ̈НA

Питання художньо-стилістичних осбливостей абсурду у німецькомовній драматургії піднімалося у роботах М. Реутової, В.С. Мукана, Т. Конєвої, Г.П. Гавришевої, М. Яснова, та ін. Проте в цих роботах автори доволі поверхнево торкалися питання формантів поетики абсурду в творчості німецькомовних драматургів, не виділяючи чітки риси і складники «театру абсурду», а відтак, експонували риси поетики абсурду в творах лише поверхнево.

Актуальність теми окресленого питання визначається необхідністю розгляду змістових та композиційних рис поетики драми абсурду в німецькомовній драматургії у творах Макса Фріша та Вольфганґа Хільдесхаймера.

Мета доповіді: визначити основні складові та специфіку поетики абсурду, а також проблему перекладу в творчості німецькомовних драматургів.

Об'єктами дослідженні стали монографрія М. Ессліна «Драма абсурду», драматичні п'єси Макса Фріша, та Фрідріха Хільдесхаймера. При проведені дослідження були використані такі методи: описовий, лінгвістичний, філологічний, біографічний, порівняльно-історичний, емпіричний методи.

Драма абсурду - сукупність явищ авангардистської драматургії в європейському театрі XX століття, узмістовлених фрілософією екзистенціалізму, в якій проблема абсурду буття — одна із центральних [1].

Першим цей термін використав британський літературознавець, перекладач, публіцист та драматург М. Есслін у своїй Монографії «Театр Абсурду» у 1961 році [2]. Варто зазначити, що твори, котрі Есслін відніс до тих, що належать до абсурдизму, вже існували на той час, він лишень ввів нове поняття у літературний світ. Також він зауважив, що під самим поняттям «театр абсурду» не має «ні організованого напряму, ні мистецької школи», адже ті, кого дослідник називав «абсурдистами» не тільки не створювали ніяких програмних текстів з і маніфестів, але й могли не спілкуватися один з одним. Есслін виділив 4 ознаки драми абсурду, а саме: інсценування, безглузді дії, мовний нонсенс і фантастика. Драма абсурду $є$ театром не сюжетним а ситуативним. В ній використовує мову образів в а не доказів чи розмов. Немала роль у подальшому сприйнятті публікою драми абсурду віддана перекладачам та інтерпретаторам творів. Можливості просто перекласти твір, 
без втрати сенсів та акцентів, що їх заклав творець у свій текст. Семюель Беккет бувши автором білінґвальним не перекладав свої ж п'єси буквально. Він їх писав наново враховуючи особливості культури тих носіїв мови, котрим було призначено ці вистави сприймати.

Мова, на котрій пише автор, впливає як на сприйняття бутя через виставу, так і на якість «абсурду», оскільки доводиться використовувати вербальну семантику, притаманну для тієї мови, котрій призначено звучати зі сцени.

Ми можемо розпочати розгляд поетики абсурду із сюжетної складової, з огляду на композиційний рівень. Здебільшого у виставах, що були написані зважаючи на лейтмотив, що досліджується, подієвість майже відсутня(точніше зведена до мінімуму). На сцені панує статика. Сюжет рухається не якась дія, поштовхом для дії вистають слова, та репліки, що проговорюються дійовою особою. Основа - це трансляція потоку інтенції, що викликані тією чи іншою проблемою, або конфрліктом. Основа - це трансляція потоку інтенції, що викликані тією чи іншою проблемою, або конфліктом.

Інструменти абсурдистів, що використовувалися ними для передачі певних проблем, явищ, та їх характеристик, дещо подібні до засобів французьких письменників епохи Ренесансу. Ix можна класифрікувати як основні та другорядні. У основі лежать гротеск та парадокс. Другорядним же є казуси, беззмістовні діалоги, буфонада, каламбури тощо. Поетика «театру абсурду» полягає у поєднанні трагічного та комічного, запозиченню елементів інших видів мистецтва: цирку, хору, мюзік-холу.

По-перше, сценічний діалог - це особливий прояв усного мовлення. Лівий вводить терміни «зручновимовляння» i «зручнорозуміння», що характеризують переклад для сцени в аспекті дикції і синтаксису. По-друге, сценічний діалог має складну семантичну структуру, так як «репліка, крім відношення до об'єкту висловлювання, вступає в цілий ряд семантичних зв'язків що йдуть за ним.»

По-третє, діалог на сцені $\epsilon$ словесною дією, котра в одних випадках визначається самою конструкцією, «прямо вказує акторові, як вимовити репліку», в інших - лише пунктирно намічається написаним текстом. Завданням перекладача Лівий бачить тут збереження принципу побудови фррази, що несе певний заряд «сценічної енергії» (темп, ритм, інтонація) [3].

Нарешті четверта характеристика, діалог на сцені - це не тільки форма побудови мови персонажів, а й одночасно їх характеристика. Перекладаючи драму абсурду, важко необхідно враховувати особливості мови, на яку перекладається твір, тому що, наприклад, одні мовні каламбури, що працюють в англійській мові, можуть не сприйнятися при перекладі на німецьку.

Для Гюнтера Грасса абсурдисьтське викриття - лише одна із складових оповіді. Специфіка його манери полягає в тому, що гротескно-абсурдний, неправдоподібний сам по собі сюжет або епізод розгортається на тлі вельми конкретних соціально-історичних, політичних, географрічно-топографічних обставин.

Творчий метод Макса Фріша є доволі своєрідним проте хвилюють його ті ж питання, що і інших сучасних письменників. Друг і колега Фріша Фрідріх Дюрренматт одного разу сказав, що справжня письменницька праця - це завжди участь в продумуванні і програванні можливостей людини. 
Театральна творчість Вольфганга Хільдесхаймера надзвичайно органічна: всі його п'єси тісно переплітаються між собою, хоча вони і відрізняються і за жанрами, і за засобами виразності, і за сюжетами, проте у всіх них відчувається приналежність їх автора до абсурдизму.

\section{Висновки.}

1) Екзистенційна змістовність $є$ невід'ємною складовою драми абсурду. Проблема самовизначення людини в світі, її неспроможність подолати виклики буття знаходять відображення у творах авторів-абсурдистів. Екзистенціалізм намагається відновити онтологію на противагу методологізму і ґносеології.

2) Обов'язкова інсенічність, мовний нонсенс, безглуздість дій, фантастика, гротеск, та сатира $€$ обо'язковими складовими драми абсурду, хоча варто зазначити, що відсутність кількох складових не не обов'язково відводить той чи інший твір від поняття драми абсурду.

3) Інтерпретація творів драми абсурду має проводитися з потрібною для того процесу увагою, так я просто перекласти або поставити п'єсу без урахування сенсових особливостей означає втратити ту думку, яку заклав автор.

4) Поетичні складові драми створюють необхідну атмосферу та настрій у читача, при котрому від включається в дію. Роздумує над сюжетом та випрацьовує особисте ставлення до того, що було показане на сцені. Дія в таких п'єсах, зазвичай статична, та обмежена однією локацією. Вона ясна і зрозуміла з перших актів. Змістовна ж складова майстерно прихована, та вимагає від глядача деякого аналізу та життєвого досвіду, щоб зуміти інтрепретувати для себе те, що відбувається на сцені.

5) Перекладати текст потрібно так, щоб текст окрім того, щоб містив у собі змістовне навантаження закладене автором, ще й було підготовлено для сценічного мовлення. Адаптація та переклад дійсно виявляють цілий ряд тотожностей: і в тому і в іншому випадку вихідний текст піддається трансформації і стає об'єктом інтерпретації, характер і мінливість яких дуже складно піддається однозначній оцінці.

\section{Список використаних джерел:}

1. Літературознавчий словник-довідник.

2. Esslin Martin. (1987). The Theatre of the Absurd (3 ed). London.

3. Левый, И. (1974). Искусство перевода. М. 


\section{КОНОТАТИВИ В МЕДІА-ДИСКУРСІ}

\section{Карабахцян Аїда Тигранівна}

студентка ОС «Магістр» спеціальності «Публічна лінгвістика» Донецького національного університету імені Василя Стуса

Медіа-дискурс - це функціонально зумовлений тип дискурсу, сукупність процесів і продуктів мовленнєвої діяльності у сфрері масової комунікації у всьому їх різноманітті та складності їх взаємодії [1]; це тематично сфокусована, соціокультурно зумовлена мовленнєво-мисленнєва діяльність у масмедійному просторі [4]; це реальність, створена засобами масової комунікації, що опосередковують продукування, зберігання і поширення суспільно важливої інформації [5]; ієрархічно організований, багаторівневий комплекс текстів, у якому тексти меншого структурно-змістового об'єму входять до більших текстових цілих (тексти преси, радіо, телебачення, мережі Інтернет) [2].

Серед класифікаційних ознак медіа-дискурсу - групова співвіднесеність (адресант поділяє погляди своєї групи); публічність (відкритість та орієнтація на широкий загал); дісенсна орієнтованість (створення протиріччя з наступною дискусією); інсценування та масова спрямованість, що передбачає одночасний вплив на кілька груп [3].

Одним із ефективних мовленнєвих засобів впливу на адресата медіадискурсу виступають конотативи. Це - лексичні одиниці (у нашому дослідженні поетоніми), які супроводжуються певним додатковим, специфічним значенням.

Приклади конотативів у медіа-дискурсі подані нижче.

\begin{tabular}{|c|c|c|}
\hline $\begin{array}{c}\text { Власна конотативна } \\
\text { назва }\end{array}$ & Значення & Приклад \\
\hline АБРАМОВИЧ & $\begin{array}{l}\text { Поширене серед євреїв } \\
\text { прізвище }\end{array}$ & $\begin{array}{l}\text { Ну, прибрали Амбрамовича, а } \\
\text { замість нього з'явиться Цукерман } \\
\text { (СОУММ). }\end{array}$ \\
\hline АЙБОЛЙТ & $\begin{array}{l}\text { Ім'я персонажа з } \\
\text { літературної казки К. І. } \\
\text { Чуковського. Варіанти: } \\
\text { Айболіт, Айболи́ть, } \\
\text { Ойболи́ть. }\end{array}$ & $\begin{array}{l}\text { Ветеринарний лікар: сучасний } \\
\text { Айболить (О. Неситов, До Дня } \\
\text { ветеринара, 08.08.2003). «Айболить» } \\
\text { черкаських звірів. На прийомі у лікаря } \\
\text { Миколи Денисенка.... (Прес-центр, м. } \\
\text { Черкаси, 04.11.2010). }\end{array}$ \\
\hline БІГ-БЕН & $\begin{array}{l}\text { Годинникова башта у } \\
\text { Лондоні, частина } \\
\text { архітектурного комплексу } \\
\text { Вестмінстерського палацу, } \\
\text { де розташовується } \\
\text { відновлений після пожежі } \\
1834 \text { р. британський } \\
\text { парламент. }\end{array}$ & $\begin{array}{l}\text { Біг-Бен відтепер є і в українській } \\
\text { Вінниці. Його встановили перед } \\
\text { місцевим педуніверситетом } \\
\text { (Подробности-ТВ. 27.06.2012). }\end{array}$ \\
\hline $\begin{array}{l}\text { БУРАТі́̈О, } \\
\text { (БУРАТЙНО) }\end{array}$ & $\begin{array}{l}\text { Iм'я дерев'яної ляльки, } \\
\text { персонажа повісті О. М. } \\
\text { Толстого „Золотий ключик, } \\
\text { або пригоди Буратіно”. }\end{array}$ & $\begin{array}{l}\text { Вічно сюди сунуть свого носа } \\
\text { Буратіни (Із телепередачі, перший } \\
\text { канал, 20.09.2007). }\end{array}$ \\
\hline
\end{tabular}


Продовження табл.

\begin{tabular}{|c|c|c|}
\hline $\begin{array}{c}\text { Власна конотативна } \\
\text { назва }\end{array}$ & Значення & Приклад \\
\hline ВАРШÁBA & $\begin{array}{l}\text { Столиця Польщі з } 1596 \\
\text { року, порт на річці Вісла, } \\
\text { адміністративний центр } \\
\text { Мазовецького воєводства. }\end{array}$ & $\begin{array}{l}19 \text { червня у Вінниці стартував } \\
\text { конкурс на кращий проект мурал - } \\
\text { арту «VIN-ARTCITY». До дня міста у } \\
\text { Вінниці п'ять будівель будуть } \\
\text { розмальовані кращими художниками. } \\
\text { Картини будуть розмальовані за } \\
\text { тематикою: Народні назви районів } \\
\text { міста: Варшава, Корея, Вишенька, } \\
\text { Іерусалімка, Ліверпуль. Організатори } \\
\text { планують залучити художників з } \\
\text { усього світу. П'ять будівель у } \\
\text { центрі Вінниці розмалюють (Новини } \\
\text { Вінниці, 19.06.2015). }\end{array}$ \\
\hline ГУЛЛІВЕ́Р (ГУЛІВЕ́Р) & $\begin{array}{l}\text { Персонаж сатирико- } \\
\text { фантастичної фантастичної } \\
\text { книги Джонатана Свіфта } \\
\text { «Подорожі Гуллівера». }\end{array}$ & $\begin{array}{l}\text { Дівчина-Гулівер: Батьки Діани в шоці } \\
\text { - їхня маленька донька росте } \\
\text { величезними темпами. Їй всього } 13 \\
\text { років, а ростом вона - вже } 180 \text { см } \\
\text { (Українська правда, 08.08.2007). }\end{array}$ \\
\hline Д’АРТАНЬЯ́Н & $\begin{array}{l}\text { Персонаж романів А. Дюма } \\
\text { про трьох мушкетерів. }\end{array}$ & $\begin{array}{l}\text { Гриценко - один Д’Артаньян, який } \\
\text { готовий пожертувавати своїм } \\
\text { депутатським статусом (У. т. - № } 6 \\
\text { (274). - 2013. - С. 15). }\end{array}$ \\
\hline ДЖЕ́ЙМС БО́НД & $\begin{array}{l}\text { Джеймс Бонд командер } \\
\text { ВМФ Великобританії, також } \\
\text { відомий як «агент 007»- } \\
\text { головний персонаж романів } \\
\text { британського письменника } \\
\text { Яна Флемінга про } \\
\text { вигаданого агента МІ6 } \\
\end{array}$ & $\begin{array}{l}\text { Минулої п'ятниці президент Лех } \\
\text { Качинський своїм указом оприлюднив } \\
\text { рапорт з усебічним аналізом } \\
\text { діяльності польських «джеймсів } \\
\text { бондів» комуністичного розливу } \\
\text { (Україна молода, 22.02.2007). }\end{array}$ \\
\hline ДІÓP & $\begin{array}{l}\text { Діор Крістіан (1905-1957) - } \\
\text { французький модельєр, } \\
\text { дизайнер, один із } \\
\text { законодавців моди середини } \\
\text { ХХ ст. }\end{array}$ & $\begin{array}{l}\text { Свого часу його (В. Зайцева - Г. Л.) } \\
\text { називали «радянським Карденом», } \\
\text { «червоним Діором» (Зайцев- } \\
\text { zaxid.net). }\end{array}$ \\
\hline EBEPÉCT & $\begin{array}{l}\text { Найвища вершина на землі, } \\
\text { в Гімалаях, на кордоні } \\
\text { Непалу й Китаю. }\end{array}$ & $\begin{array}{l}\text { I при цьому „Берестечко” все одно } \\
\text { Еверестом вивищується над } \\
\text { більшістю інших спроб українських } \\
\text { авторів літературно використати } \\
\text { сумні подї вітчизняної історії, з } \\
\text { їхнью нестерпною шароварщиною } \\
\text { (Національний альянс, 12.05.2010). }\end{array}$ \\
\hline ЕЙНШТЕ́ЙН Альбёрт & $\begin{array}{l}\text { Видатний німецький і } \\
\text { американський фізик (1879- } \\
\text { 1955). }\end{array}$ & $\begin{array}{l}\text { Киянин Едуард Яковлєв розробив } \\
\text { методику пошуку ейнштейнів. } 3 \\
1983 \text { року він намагається торувати } \\
\text { дорогу своєму відкриттю. Щоправда, } \\
\text { подібними речами цікавився Зигмуннд } \\
\text { Фрейд... (Урядовий кур'єр, } \\
\text { 09.12.2000). }\end{array}$ \\
\hline ЕЛЬДОРА́ДО & $\begin{array}{l}\text { Неіснуюча країна, начебто } \\
\text { багата золотом і } \\
\text { дорогоцінними мінералами, } \\
\text { яку шукали на території } \\
\text { Латинської Америки перші } \\
\text { іспанські завойовники (XVI } \\
\text { ст.) }\end{array}$ & $\begin{array}{l}\text { „Аборигени і заброди у пошуках } \\
\text { Ельдорадо” - назва статті про } \\
\text { українських безробітних (Україна, № } \\
5,2004) .\end{array}$ \\
\hline
\end{tabular}


December 13, 2019 • Valletta, Republic of Malta $\bullet 103$

Продовження табл.

\begin{tabular}{|c|c|c|}
\hline $\begin{array}{c}\text { Власна конотативна } \\
\text { назва }\end{array}$ & Значення & Приклад \\
\hline ЄВРО́ПА & $\begin{array}{l}\text { Частина світу на північній } \\
\text { півкулі; з Азією утворює } \\
\text { континент Євразію. }\end{array}$ & $\begin{array}{l}\text { У } 18 \text { років, після закінчення коледжу, } \\
\text { я поїхав у Європи (Post-Поступ, № 6, } \\
\text { 2007). }\end{array}$ \\
\hline IBÁH IBÁHOВИЧ & $\begin{array}{l}\text { Поширене антропонімне } \\
\text { сполучення. }\end{array}$ & $\begin{array}{l}\text { «Де ж той Ван Ванич?» - назва } \\
\text { статті Веле Штилверда (Леоніда } \\
\text { Нефедова) (Українська правда, } \\
\text { 27.02.2009) }\end{array}$ \\
\hline
\end{tabular}

\section{Список використаних джерел:}

1. Добросклонская, Т.Г. (2014). Массмедийный дискурс как объект научного описания. Научные ведомости БелГУ. Серия: Гуманитарные науки. Минск, 13 (184). 181-187.

2. Желтухина, М. Р. (2009). Взаимодействие дискурсов в массмедиальном пространстве. Актуальные процессы в различных типах дискурсов: политический, медийный, рекламный дискурсы и интернет-коммуникация: материалы международной конференции (с.137-143).

4. Желтухина, М. Р. (2007). О содержании дискурса масс-медиа. Вісник Луганського педагогічного університету імені Тараса Шевченка. Луганськ, 11 (128), 27-40.

5. Кожемякин, Е. А. (2010). Массовая коммуникация и медиадискурс: к методологии исследования. Научные ведомости БелГУ. Серия: Гуманитарные науки. Минск, 12(83), 1321.

6. Кубрякова, Е. С. (2004). Язык и знание: На пути получения знаний о языке: Части речи с когнитивной точки зрения. Роль языка в понимании мира. М.: Языки славянской культуры.

\section{ОСОБЛИВОСТІ ПЕРЕКЛАДУ ОБСТАВИНИ В ХУДОЖНІЙ ЛITEPATУPI}

\section{Волянюк Іванна Юріївна}

здобувач вищої освіти факультету лінгвістики та соціальних комунікацій Національний авіаційний університет

НАУКОВИЙ КЕРІВНИК:

Сітко Алла Василівна кандидат філологічних наук, доцент кафедри англійської фрілології і перекладу Національний авіаційний університет УКРАЇHA

Серед багатьох складних питань, які вивчає сучасне мовознавство, важливе місце посідають проблеми перекладу, оскільки процес перекладу не $€$ простою заміною одиниць однієї мови одиницями іншої, а, навпаки, це складний процес, який містить цілу низку операцій, знання яких перекладачем $€$ запорукою адекватного перекладу [1].

Як справедливо стверджує А.Сітко труднощі виникають у процесі перекладу з англійської мови на українську, головним чином, через розходження в граматичному ладі англійської й української мов. Англійська і українська мови належать не тільки до різних гілок індоєвропейської родини 
мов, а й до різних структурних типів мов: перша - переважно аналітична мова, а друга - фрлективна мова [2]. На сучасному етапі розвитку суспільства, наукової та технічної думки рівень цікавості до перекладу та різноманітних питань, поєднаних з ним, зростає. Але треба відзначити, що далеко не всі аспекти перекладу як науки $€$ однаково дослідженими. Одним 3 таких малодосліджених низань є проблема перекладу обставини [3].

The Adverbial Modifier (обставина) - другорядний член речення, що доповнює дієслово, прикметник або ж прислівник, тобто залежить від присудкової частини речення. Обставина пояснює, яким чином, де і коли виконується певна дія або ж протікає стан, виражений присудковою частиною.

Linda runs fast. - Лінда швидко бігає.

Jean likes to read in the garden. - Жан любить читати у саду.

I will be home around 6 p.m. - Я буду вдома приблизно о 6-й вечора.

Обставина в англійській мові, як і в українській мові - це другорядний член речення, який означає різні характеристики дії (час, місце, причину, мету і т. п.), а також ступінь якості [4]. За значенням обставини поділяються на обставини місця, часу, частоти та повторюваності, способу дії, причини, мети, результату і ступеня.

Обставини найчастіше виражаються іменниками з прийменниками. Крім іменника з прийменником і прислівника, обставини можуть бути виражені такими словами або групами слів: дієприкметником або дієприкметниковим зворотом, іменником без прийменника, інфінітивом (обставина мети або наслідку), герундієм 3 прийменником, синтаксичним комплексом 3 дієприкметником або інфрінітивом (складна обставина), обставинним підрядним реченням [4].

Обставини в англійській мові можуть стояти на початку, в кінці і в середині речення. Проте місце обставини залежить від її значення і способу вираження, і певні види обставин мають свої місця в реченні. Загальним правилом $є$ те, що обставина не може відокремлювати додаток від дієслова (тобто стояти між дієсловом і його додатком) [4].

Пропонуємо розглянути особливості перекладу обставини на прикладі роману «Робінзон Крузо» Даніеля Дефо та його перекладу, виконаному Володимирем Верховинцем.

"I was born in the year 1632, in the city of York, of a good family, though not of that country, my father being a foreigner of Bremen, who settled first at Hull" [5]. «Я народився 1632 року в місті Йорку в порядній сім'ї, хоч і не корінного походження: батько мій був родом із Бремена й оселився спочатку в Гуллі»[6].

"But I would be satisfied with nothing but going to sea"[5]. - «Але мене вже нічого не радувало, крім поїзди в море» [6].

У поданих прикладах в оригінальному реченні використовується обставина місця. У перекладі українською мовою застосовані також обставина місця, оскільки вказано чітко місце.

"I spent this day in covering and securing the goods which I had saved, that the rain might not spoil them" [5]. - «Я провів цей день аби прикрити та сховати майно, щоб дощ не зіпсував його» [6].

"I worked very hard in carrying all my goods to my new habitation, though some part of the time it rained exceedingly hard." - Я старанно працював, щоб 
доставити всі свої речі в нову оселю, хоча через дощ все ускладнювалось» [6].

В наведених прикладах речення оригіналу, так і в перекладі українською мовою, використана обставина мети, оскільки можна поставити питання з якою метою?

"I was still deficient, for I wanted a basket or a wheelbarrow" [5]. - «Мені все ще не вистачало кошика або тачки, тому що вони були мені потрібні» [6].

"My other work having now stood still, because of my making these tools"[5]. «Моя інша робота зараз стоїть на місці, через те, що я роблю ці інструменти» [6].

У поданому прикладі оригінального речення, автор використав обставину причину, так само і в перекладі ми можемо спостерігати приклад обставини причини, оскільки ми можемо поставити запитання через що? 3 якої причини?

Висновки. Пропонована робота присвячена розгляду особливостей перекладу обставини в художній літературі. Матеріалом нашого дослідження слугував твір «Робінзон Крузо» Даніеля Дефо. Нами було зафіксовано вживання при перекладі найчастіше обставин місця, причини та мети.

Отже, якщо взяти до прикладу українську художню літературу, то випадків вживання обставини місця, причини та мети значно більше, аніж в англійській художній літературі. Тому справедливим уважаємо твердження, що у синтаксисі найповніше виражається мовна специфіка, ось чому очевидно, що саме від того, наскільки майстерно перекладач зуміє цільовою мовою відтворити особливості синтаксису художнього твору, настільки легше цей твір уживається в нову мовну тканину й цілісніше сприйматиметься читачем [2].

\section{Список використаних джерел:}

1. Сітко, А.В. (2012). Проблема відтворення граматичної семантики інтерогативів засобами цільової мови. Проблеми семантики, прагматики та когнітивної лінгвістики. К. : Логос (22), 267-274.

2. Набігуз, А. \& Сітко, А. (2019). Використання комплексного підходу до художнього перекладу. Фаховий та художній переклад: теорія, методологія, практика. К.: Аграр Медіа Груп, 3340.

3. Сітко, А.В. (2013). Використання результатів контрастивних досліджень у перекладознавстві. Наукові записки. Серія : Філологічні науки (мовознавство). Кіровоград : РВВ КДПУ ім. В. Винниченка (116),199-203.

4. Мушніна, О.О. (2002). Граматичні особливості науково-технічного перекладу у порівнянні 3 художнім прозовим перекладом (англо-українські паралелі). Мовні і концептуальні картини світу: Збірник наукових праць. К:: Київський університет(7), 368-372.

5. Defoe, D. (2016). The Life and Strange Surprising Adventures of Robinson Crusoe of York, Mariner. New York.

6. Дефо, Д. (2013). Пригоди Робінзона Крузо. Переклад з аглійської Володимир Верховинець. Київ ВД «Фоліо». 


\title{
ОСОБЛИВОСТІ ПЕРЕКЛАДУ ВЛАСНИХ НАЗВ
}

\author{
Кіщенко А.Ю
}

магістрант 6-го року навчання фракультету іноземних мов Вінницький державний педагогічний університет ім. Коцюбинського

НАУКОВИЙ КЕРІВНИК:

Ямчинська Т.І. кандидат фрілологічних наук, доцент, декан фракультету іноземних мов Вінницький державний педагогічний університет ім. Коцюбинського

УКРӒ̈HA

Переклад власних назв - важливий аспект роботи перекладача. Існує багато визначень поняттю «власна назва». Так, наприклад, Дж. С. Мілль зазначав, що власні назви-це назви, що не несуть значення, вони - це особливі ярлики чи мітки, які допомагають впізнавати та розрізняти назви.

О. В. Бока називає власні назви своєрідними культурно-історичними та мовними індексами, джерелом вивчення лексичного багатства мови, оскільки відбивають назви предметів реалій та понять і $€$ специфічними для певної країни або нації [1].

Всі власні назви мають значення предметності. Тобто вони несуть в собі інформацію про предмет та його властивості. Важливо зазначити, що без збереження свого значення власні імена не можуть існувати. У цьому і полягає складність перекладу і проблеми не точного сприйняття тексту.

Головна особливість власних назв полягає в тому, що при перекладі, вони не втрачають свою звукову форму. В початковому мовному середовищі вони мають складну смислову структуру, унікальні форми та етимологію, багаточисленними зв'язками з другими одиницями мови.

І. В. Корунець виділяє такі способи перекладу антропонімів: транслітерація, транскрибування та калькування [2]. При будь-якому способі незмінною для перекладача $€$ настанова: внутрішня форма (зміст, наповненість) має відповідати зовнішній (форма вираження, тобто, морфологічна форма).

Перекладацька транскрипція - це пофонемне відтворення вихідної лексичної одиниці за допомогою фонем мови перекладу, фонетична імітація вихідного слова.

За визначенням М. С. Зарицького, транслітерація - це переклад на рівні графем, політерне відтворення назв літер однієї системи письма назвами літер іншої системи письма. [3].

Обидва ці способи є найбільш лаконічними, так як калькування полягає у дослівному перекладі власного імені по частинам з наступним складанням цих частин в одне ціле. Найчастіше для передачі власних назв використовують транскрипцію.

Отже, процес перекладу власних назв - один із найскладніших. Він полягає в аналізі компонентів початкового тексту та синтезу його значення. Зміст антропонімів слід не просто передати, а й перенести на відповідний культурний грунт. 


\section{Список використаних джерел:}

1. Бока, О. В. (2008) Власні імена як компресовані тексти-носії когнітивної інфформації Філологія (1), 15-19.

2. Корунець, І.В.(2001) Теорія і практика перекладу (аспектний переклад) (с.448) Вінниця. : Нова книга.

3. Зарицький, М. С. (2004) Переклад: створення та редагування (с. 120) К.: Парламентське видавництво.

\section{СПОСОБИ ПЕРЕКЛАДУ ЗАЧИНІВ І КІНЦІВОК УКРАЇНСЬКИХ НАРОДНИХ КАЗОК}

\section{Рудченко Юлія Русланівна}

здобувач вищої освіти факультету лінгвістики та соціальних комунікацій Національний авіаційний університет

Сітко Алла Василівна

канд. фрілол. наук, доцент, доцент кафедри англійської фрілології і перекладу Національний авіаційний університет

УKPAÏHA

Перекладна література, що потрапляє в культурний простір кожного народу, вступаючи у складні взаємостосунки з його оригінальною літературою, суттєво доповнює літературний процес, розширює його тематичні, жанровозмістові, естетичні межі. Українські народні казки є неабиякою цінністю завдяки своєрідним зачинам та кінцівкам, які пронизані атмосферою загадковості, гострими враженнями, магією, чудесами та, звичайно, безкінечним гумором, що вирізняє ії серед казок інших народів та робить надзвичайно специфічною, оскільки першотвір як єдиний об'єкт відображення наштовхує нас на ідею абсолютної самоцінності мистецтва, так званого «чистого мистецтва». Такі усталені словосполучення та вирази роблять для читача доступними знання і мудрість наших предків, ось чому для перекладача важливо поринути у джерело з живою мовою, черпнути та донести до читача ії̈ живлющу силу, не розбризкавши, крокуючи по тернистому шляху перекладача.

Переклад української казки на англійську манеру $є$ досить нелегким завданням, оскільки маленьких читачів практично неможливо ввести в оману, та підсунути їм транскрибований переклад, так як їхня франтазія диктує зовсім інші правила. Звідси й виникає ціла низка проблем для перекладача стосовно релевантної передачі українських зачинів та кінцівок англійською мовою. Адже справедливим уважаємо твердження про те, що при спробі перетворити етномовні образи казкового світу з однієї мовної системи в іншу необхідно враховувати не лише специфіку жанру та літературні традиції, а також етномовну комунікативну компетенцію адресата [1].

Перенесення читача іншомовної культури в світ української народної казки, де в перших рядках ми зустрічаємо бурхливий потік емоційно-експресивної 
лексики, з маркерами існуючих місць і реальних подій $є$ досить важким завданням. Серед числа визначних дослідників української народної казки слід відзначити: І. Желєзнову, А.М. Біленко, М.Ф. Скрипник, Р.Н. Бейн. Запорукою успішного перекладу вважають прекрасні знання традицій, національної специфіки українського народу, вміння застосовувати свій когнітивний досвід в руслі іншої культури. Звичайно, що не можливо передати усі елементи, на позначення національного колориту, але їх і не обов'язково всі перекладати, вистачить лише його головних проявів.

Виділяють декілька суттєвих факторів, які слід врахувати у процесі перекладу зачинів українських казок:

- реальні факти (наприклад, «Було це давно-давно, коли ще люди ходили на панщину» [2]; «Давним-давно були такі часи, що молодих хлопців кликали в армію, коли їм було двадцять» [3] );

- регіональні маркери (наприклад, «Жили в Новому Давидкові, на Мукачівщині, чоловік з жінкою». (с. Нове Давидково Мукачівського р-ну, Закарпатської обл.) [3]; «Одного разу в селі Меловому на Херсонщині в одного чоловіка був жвавий хлопчина, з яким батько завше рибальчив» (с. Милове Бериславського р-ну Херсонської обл.) [2];

- римовані повтори (наприклад, «Десь-не-десь, в тридесятому царстві, в іншій державі жив цар з царицею чи князь із княгинею, і було в них два сини»; «Раз був, де не був, у тій землі, де уже край світу, один чоловік» [2]; «Жив, де не жив, один багатий графр» [3]; «Був - не був, та кажуть люди, що був, дуже багатий пан-дідич» [2].

Кожен із вище зазначених факторів доносить до реципієнта вагому інформацію про історію українського народу, його стиль життя, своєрідності мови та мислення. Це не означає, що перекладачі не повинні брати до уваги інші зачинові реалії, однак вони можуть бути частково адаптовані до культури мови перекладу, адже «вживання тих чи тих слів, словосполучень, зворотів безсумнівно впливатиме на семантику речення» [4]. Зокрема, в українських зачинах переважають прості речення, тоді як складносурядні речення краще підходять для сприйняття іншомовного читача, при цьому граматичні трансформації такого типу не призводять до спотворення контексту. Проілюструємо цю особливість за допомогою наступних прикладів:

«У лісі да жила лисиця, а біля того ліса да жив собі чоловік. У того чоловіка да був кіт. Він колись добре мишей ловив, а далі, як осліп, дак $і$ перестав» [2]. - "In - a certain forest there once lived a fox, and near to the fox lived a mn who had a cat that had been a good mouser in its youth, but was now old and half blind" [5].

Національний колорит не порушується у разі заміни зачину української народної казки традиційною англійською конструкцією такою як "Once upon a time.... Розглянемо наступні приклади:

«Жив колись (раз, собі)» [3]. - "There was once upon a time..., Once upon a time there lived.... There once was..." [6].

Однак, саме можливість зробити казку відповідною для сприйняття іншомовного реципієнта, може стати причиною неточностей та невідповідностей, зокрема тих перекладачів, для котрих українська мова не $є$ 
рідною. Як відомо, казка не обмежується традиційною формулою обрамлення, разом із маркерами часу та місця, переліком головних персонажів, їхнього соціального статусу, отож казкарі з величезною майстерністю та в стислій формі намагаються передати живу українську мову, що іноді зазнає невдачі в англійському перекладі. Таку закономірність можна простежити на прикладі казки «Ox!».

«Колись було не так, як тепер: колись усякі дива робилися на світі, і світ був не такий як зараз. Нині цього всього немає... Розкажу вам казку про лісового царя Оха, який він був» [3]. - "The olden times were not like the times we live in. In the olden times all manner of Evil Powers walked abroad. The world itself was not then as it is now: now there are no such Evil Powers among us. I'll tell you a kazka of Oh, the Tsar of the Forest, that you may know what manner of being he was" [6].

У цьому прикладі неможливо не звернути увагу на очевидний казус, котрий відбувся при перекладі слова «диво». Перекладач вибрав словосполучення "Evil Power", зазначивши в примітках до тексту, що "Divo. This ancient, untranslatable word (comp. Latiu Deus) is probably of Lithuanian origin, and means any malefic power" і певною мірою мав рацію. Словник подає наступне тлумачення цього слова: «Диво - у дохристиянських віруваннях - зле божество-дракон, чудовисько; слово, яке споріднене зі словами диво, дивний, пов'язаними, у свою чергу, із санскритським і перським Deva «божество», латинським Deus «бог», грецьким Zeus «Зевс»; через втрату первісного значення слова за його похідними залишилася семантика незвичайності, чуда, рідкісного феномена або ознаки, які межують з надприродністю» [7]. 3 цього виникає певна суперечність, чи варто розцінювати варіант перекладу як невдалий або помилковий, що спричинив спотворення сюжету, або, навпаки, як вдалу спробу донести до реципієнта національно-збагачене та розширене значення українського слова «диво». Беручи до уваги той загальновідомий фракт, що українська народна казка з'явилася в англомовному світі у 70-х роках XIX ст., a P.Н. Бейн відомий як один із перших перекладачів, слово «диво» пристосоване під наше розуміння як «рідкісне або раніше не бачене явище; щось особливе та незвичайне, таке, що викликає захоплення та здивування», це лексичне значення вживалося лише в тісних народних кругах на період його творчості та нечасто застосовувалося за своїм призначенням, ось чому це помилкове трактування можна деякою мірою виправдати [8].

«Колись-то давно, не за нашої пам'яті, - мабуть, ще й батьків і дідів наших не було на світі, - жив собі убогий чоловік з жінкою, а у них був один син, та й таке ледещо той одинчик, що лишенько!» [3]. - "Once upon - a time, long long ago, beyond the times that we can call to mind, were yet our greatgrandfathers or their grandfathers had been born into the world, there lived a poor maan and his wife, and they had one only son, who was not as an only son ought to be to his old father and mother. So idle and lazy was that only son that Heaven help him!" [6].

Інший казус можемо спостерігати у слові «лишенько», яке український читач сприймає на позначення лиха, горя, біди, зневіри та відчаю батьків за лінивого сина, а в англомовному перекладі «лишенько» має перекладацький 
відповідник: "Heaven help him", що не компенсує колоритне забарвлення українського слова. Такий вибір здебільшого зумовлений російськими словами-реаліями, оскільки українські казки були перекладені з англійської мови російською. Можна проілюструвати цю закономірність шляхом порівняння перекладів:

«Давным-давно, не на нашей памяти, а пожалуй, когда еще и отиов, и дедов наших не было на свете, жил-был бедный мужик с женой, у них был всего один сын, да и тот не такой, как надо: уродился такой ленивец, что и не приведи господи!» [9].

Очевидно, що у цьому зачині застосування прийому транскрибування $\epsilon$ невдалим, який часто застосовують при перекладі казок, але, як правило, цей прийом позбавлений змісту та не забезпечує релевантного «перенесення літературного твору крізь призму однієї сорери ментальності в іншу», тим самим ускладнюючи розуміння і без того лексично насичених зачинів та кінцівок [10].

Слова, які піддаються транслітерації, зокрема: kazka, mead, tsar, tsaritsa [5], мають прекрасні словникові відповідники в англійській мові. Здебільшого такі слова не віддзеркалюють національного українського колориту, а їх заміна англійськими лексичними відповідниками "fairy-tale" (folk tale) [8], "honey" [5], "king" [6], "queen" [5] лише допомагає іншомовному реципієнту прочитати казку від початку до кінця з розумінням, не звертаючи уваги на незрозумілі графеми.

Порівняно з відтворенням зачинів англійською мовою, при передачі фрінальних фоормул української казки виникає менше труднощів, які виступають маркерами кінцевого благополуччя героїв, так як в англійських казках присутні їх еквівалентні відповідники. Проблема перекладача полягає в тому, що потрібно передати все розмаїття фрінальних формул українських казок «бідними фрормальними засобами англійської мови», які, окрім різних варіантів підтвердження кінцевого благополуччя героїв, також включають в себе ряд інших нюансів [11]. До своєрідних особливостей кінцівки слід віднести жартівливі римовані кінцівки, які здебільшого не мають спільних рис із сюжетом казки. Проілюструємо цю характерну особливість за допомогою наступних прикладів:

"I кінець кінцем, бо курка з яйцем» [2]; «Поїхали в ліс, вирубали ківщ, то ще б казки було більщ» [3]; «Між тими квітами пишно розцвіла червона півоня, а чю казку розказала Юрчачка Доня» [2]; “Сіла баба на стілець, а нашій казці кінець» [3].

У наведених вище прикладах спостерігається наявність римованих кінцівок, а саме «кінець...яйцем», «червона півоня...Юрчанка Доня», «стілець...казці кінець». Римована кінцівка підсилює значущість наявних у творі жартівливих кінцівок для того, щоб зацікавити дитячу читацьку аудиторію.

У деяких кінцівках казок часто зустрічаються жартівливі фрази, особливо слово «горнець», яке казкарі використовують зокрема через його визначне магічно-сакральне значення для української спільноти. За давнім народним повір'ям, дбайлива господиня не залишає горщики відкритими, особливо на ніч, адже туди може впасти щось нечисте; розбитий горщик здавна був 
символом руїни, сварок та розбрату; дірявий горщик символізував неробу та марнотратника; щербатий горщик вважався прикметою нещасливої, безталанної людини [12]. Наведемо наступні приклади:

"Сказився бабин горнець, та й казці кінець» [3].

У цьому випадку «горнець» $€$ символом нещасливого кінця казки, а саме вказує на те, що бабі не вдалося досягти свого та забрати семирічного хлопчика за колись укладений договір.

«Розбився горнець - нашій казці кінець» [3].

У запропонованому реченні жартівлива фрраза «горнець» символізує щирі вірування народу, які походять із далекої язичницької давнини, коли вірили в прикмети, у цьому випадку «горнець» використовується на позначення розбрату та невдалого завершення сюжету казки.

«На радості жінка розбила глиняний горнець, і нашій казочці кінець» [10].

Даний приклад свідчить про використання слова «горнець», яке має зовсім протилежне символічне значення до згаданих вище, адже жінка розбила горщик на радощах, що блудний чоловік повернувся додому після своїх життєвих пригод.

Наведені вище кінцівки, зокрема римовані жартівливі вислови та словасимволи, мають важливе значення при перекладі, та не підлягають калькуванню або транслітерації. Більшість перекладачів ретельно відбирають влучний переклад серед запропонованих вище кінцівок, проте не можна уникнути казусів, які в основному стосуються неправильного пошуку відповідника. Наприклад, у казці «Старий собака» перекладач вирішив доцільним застосувати творчий підхід при перекладі, внаслідок чого утворилася розширена кінцівка, в сюжеті якої з'являється ще одна дійова особа, а також відбулася конкретизація періоду часу, в результаті словосполучення «крихта хліба» перетворилося у перекладі на "a large lump of bread".

Для порівняння наведемо приклади, взяті з текстів оригіналу і перекладу:

"Дак жінка і дала собаці кришку хліба" [2]. - "And henceforth the woman and her husband gave the old dog a large lump of bread every day" [5].

3 урахуванням того, що під висловом «крихта хліба» у даному контексті мається на увазі малий кусень або крихта, у перекладі буде доцільно вжити відповідне англійське словосполучення "a little slice of bread".

Інший казус відбувся наприкінці казки «Лисиця та кіт», де у творі перекладу також не обійшлося без творчого втручання перекладача. У результаті, відома у всьому світі українська лексична одиниця «сало» перейняла на себе образ "bacon" і перетворилася з жиру на м'ясо. Розглянемо наступний приклад:

«A кіт зоставсь. Сидить да сала їсть, а лисиця - мед. Поїли гарненько собі да й пішли додому» [3]. - "But the cat remained in the midst of all the good things and ate away at the bacon, and the little fox gobbled up the honey, and they ate and ate till they couldn't eat any more, and then they both went home licking their paws" [6]. 
У даному випадку переклад, безумовно, можна вдосконалити, адже в словесній скарбниці англійської мови існує доречний словниковий еквівалент українського слова «сало» - "pork lard" [13].

Таким чином, при перекладі зачинів української народної казки, необхідно брати до уваги певні фактори, такі як реальні факти, регіональні маркери та римовані повтори, оскільки доволі важко передати своєрідний український національний колорит англомовному читачеві. Стосовно заключних фрормул української казки, то перед перекладачем постає проблема передати не лише кінцеве благополуччя героїв, а також своєрідні жартівливі фрази. Наведені приклади $\epsilon$ свідченням того, що при перекладі не завжди можна уникнути казусів, тому вони лише підтверджують спроби автора перекладу адаптувати твір української казки для сприйняття іншомовним читачем через гаму лексичних відповідників, прийомом додавання і пояснення.

\section{Список використаних джерел:}

1. Сітко А.В. \& Скавронська А. (2016). Етномовний компонент українських народних казок як проблема перекладу. Фаховий та художній переклад: теорія, методологія, практика: IX міжнар. наук.-практ. конф. (м. Київ, 15-16 квітня 2016 р.). Київ, Україна.

2. Дмитренко, М. К. (уклад.). (1089). Українські народні казки. Київ: Веселка.

4. Каущак Т. (2006). Казки українською мовою. Вилучено з http://kazky.org.ua/zbirky/ukrajinsjkinarodni-kazky.

5. Сітко А. \& Данилюк Ю. (2019). Фактори, що зумовлюють комунікативну варіативність під час перекладу. Фаховий та художній переклад: теорія, методологія, практика: збірник наукових праць. К.: Аграр Медіа Груп.

6. Ukrainian folk tales. (1986). (Transl. by I. Zheleznova). Kiev: Dnipro.

7. Cossack fairy tales and folk-tales (1894). (Transl. by R. Bain Nisbet). NewYork: A.L. Burt Company.

8. Крисін, Л.П. (2005) Тлумачний словник іншомовних слів. Москва: ЕКСМО.

9. Вежбицкая, А. (2001). Понимание культур через посредство ключевых слов. Москва: Языки славянской культуры.

10. Афранасьева, А. Н. (сост.). (1982). Народные русские сказки. Москва: Правда.

11. Медвідь, О. С. (1992). Нові переклади українських народних казок - англомовному читачеві. Київ: КНУ.

12. Бархударов, Л. С. (1975). Язык и перевод. Вопросы общей и частной теории переводов. Москва: Международные отношения.

13. Егорова, О. А. (2002). Традиционные формулы как явление народной культуры: на материале русской и английской фольклорной сказки (дис. ... канд. культурол. наук). Москва, Российкая Федерация.

14. Загнітко, А. П. \& Данилюк, І. Г. (2008). Великий сучасний англо-український українськоанглійський словник. Донецьк: ТОВ ВКФ «БАО». 


\section{СУЧАСНІ АНГЛІЙСЬКІ НЕОЛОГІЗМИ ТА СПОСОБИ ЇХ ПЕРЕКЛАДУ УКРАЇНСЬКОЮ МОВОЮ}

\section{Костенко Ольга Геннадіївна}

старший викладач кафедри українознавства та іноземних мов Дніпропетровський державний університет внутрішніх справ

УКРӒ̈HA

Збагачення словникового складу мови є необхідною умовою її існування. Стрімкий розвиток технологій у сучасному світі і поява нових можливостей забезпечує постійне поповнення мови новою лексикою, а необхідність її вивчення і опису обумовило створення та розвиток окремої галузі лінгвістичної науки - неології. Дослідження у галузі неології охоплюють чимало питань 3 метою пояснити поняття неологізму, процес виникнення нових слів, а також зміни, які новітня лексика вносить у розвиток мови. Для того, щоб охопити всі аспекти дослідження появи і фуункціонування неологізмів, сформувалися підходи до вивчення цього явища, які варто розглянути детальніше.

Переклад неологізмів має свої труднощі, оскільки жоден словник на тлі сучасного розвитку інформаційно-комунікаційних систем не може встигнути зафріксувати усі неологізми, що виникають. Іноді перекладачеві допомагає контекст, знання складових частин неологізму, а також розуміння способів творення сучасних англійських неологізмів. Однак досить часто цього виявляється недостатньо, і перекладач, який не володіє екстралінгвістичними знаннями, не може адекватно перекласти певний неологізм. Варто також відзначити, що не всі суспільства розвиваються рівномірно, щоможе призвести до того, що мова, на яку здійснюється переклад, може ще не мати еквівалента певному неологізму. Розглянемо найбільш поширені способи перекладу англійських неологізмів українською мовою:

1. Транскрибування, транслітерація. Такий вид перекладу передбачає відтворення форми лексичної одиниці оригіналу за допомогою літер мови перекладу. Такий вид перекладу можна назвати фактично запозиченням звукової (транскрипція) або графрічної (транслітерація) фооми слова зі збереження значенням слова з мови оригіналу в мову перекладу. Таким чином, запозичене слово стає фактом мови перекладу і виступає еквівалентом ідентичного з ним іншомовного слова. В дійсності такий спосіб $є$ одним 3 найдавніших і в наш час продовжує активно використовуватись [3].

Транслітерація відрізняється від транскрибування тим, що за допомогою українських літер необхідно передати літери, з яких складається англійський неологізм. Так, перекладачеві необов'язково потрібно знати вимову англійського слова, можна обмежитись його зоровим сприйняттям.

Серед цих двох видів перекладу поширенішим все ж таки $\epsilon$ транскрибування, яке полягає в передачі фонетичної форми англійського слова українськими літерами [3].

Розглянемо такі приклади застосування транскрибування та транслітерації при перекладі неологізмів: Brexit - Брекзит, brexchosis - Брекзхозис, hashtag - xeumez, subtweet - caбтвіm, hate-link - хейт-лінк, Cyberchondria Кіберхондрія, droniquette - Дроникет, feminocracy - феменократія, infoganda інфооганда, facepalm - феейспалм.

2. Калькування. Такий вид перекладу передбачає заміну складових частин лексичної одиниці оригіналу або цілого слова їх лексичними відповідниками в 
мові перекладу. Калькування припускає існування двосторонніх міжмовних відповідностей між елементарними лексичними одиницями [1]. Перевага такого виду перекладу полягає у стислості і простоті отримуваного з його допомогою еквівалента, також його однозначній співвіднесеності з початковим словом. Наприклад, iFinger - АйПалець, fog computing - туманні обчислення, nontroversy - псевдо дискусія, те time - час для себе, digital crowding цифрове скупчення, community animator - громадський аніматор, tweetstorm - твіт иторм, just-in-time politics - своєчасна політика, digital hangover цифрове похмілля

3. Описовий переклад - це лексико-граматична трансформація, під час якої лексична одиниця мови оригіналу, замінюється словосполученням, що роз'яснює її значення, таким чином, що вона отримує повне пояснення або визначення мовою перекладу [3]. Наприклад: skype sleep - спілкуватися за допомогою програми Skyре та заснути одночасно із своїм співрозмовником, Sellebrity - використання відомих людей для рекламування продуктів, textwalk - писати повідомлення на мобільному телефоні у соціальних мережах на ходу, Tech-life balance - час, який людина витрачає на користування різними технічними комунікативними пристроями та час без них, facecrook - злочинець, який використовує Фейсбук для здійснення, планування або обговорення злочину, Youthquake - визначні політичні, соціальні або культурні зміни, які відбулися під впливом дія та переконань молоді, diss tweet - нешаноблива або образлива публікація в Tвітmері, Cli-fi - науковофантастичний фрільм про зміну клімату, clique stalking - потайки дізнаватися про друзів людини в соціальних мережах.

4. Пряме включення - спосіб перекладу, який передбачає використання англійського слова в його початковій формі. Наприклад: wi-fi, iPod, iPad. Досить часто такий спосіб перекладу використовують для перекладу неологізмів, що складаються 3 двох частин, де одна з них подається мовою оригіналу, наприклад: web-cmoрінка [2].

5. Приблизний переклад - спосіб перекладу, за якого використовуються лексичні одиниці мови перекладу, які можуть частково відповідати безеквівалентній лексиці мови оригіналу [3]. У результаті такого перекладу значення слова загалом зберігається, однак може втрачатись його стилістичний фрон. Наприклад: nerd - неприємна, неприваблива людина, wimp - слабка людина, невдаха, buddy - друг, товариш.

Висновок. Оскільки неологізми охоплюють практично всі сфрери життя і лексичний склад англійської мови постійно поповнюється ними, розуміти, яким чином необхідно перекладати дані лексичні одиниці українською мовою. Найбільш поширеними способами перекладу англійських неологізмів українською мовою є: транскрибування/транслітерація, калькування, описовий переклад, пряме включення, приблизний переклад.

\section{Список використаних джерел:}

1. Борисова, О. В. (2008). Способи перекладу неологізмів та особливості їх опанування студентами на заняттях з практики перекладу. Мовні та концептуальні картини світу. Збірник наукових праць, 24(1).

2. Козаченко, І.В. (2014). Особливості перекладу неологізмів англійської мови. Науковий вісник Міжнародного гуманітарного університету. Сер.: Філологія, 25(2), 166-168.

3. Комиссаров, В.Н. (2011). Современное переводоведение. Москва: Р.Валент. 


\section{ФРАЗЕОЛОГІЗМИ В ТЕКСТАХ ВИСТУПІВ ГЛАВ ДЕЛЕГАЦІЙ УРСР НА СЕСІЯХ ГЕНЕРАЛЬНОÏ АСАМБЛЕЇ ООН}

Канкаш Галина Дмитрівна

Сумський національний аграрний університет

УКРÄ̈HA

У сучасному мовознавстві питанням семантичної та емоційно-експресивної ролі фрразеологізмів приділяється чимала увага, проте $є$ актуальним питання щодо використання фрразеологізмів в українських дипломатичних текстах II половини 50 - початку 70 років XX століття, оскільки цей період розвитку офіційно-ділового стилю в цілому й дипломатичного підстилю зокрема не піддавався висвітленню в наукових розвідках.

Розглянуто тексти виступів глав делегацій УРСР на сесіях Генеральної асамблеї ООН, зокрема виступи міністрів закордонних справ УРСР Л.Х. Паламарчука, Д.З. Білоколоса, заступника Голови Ради Міністрів УРСР П.Т. Тронька, Голови Ради Міністрів УРСР В.В. Щербицького. Спостереження засвідчили, що для укладання таких текстів активно використовувалися фрразеологізми.

Фразеологізми поділяються на книжні, розмовні, фрольклорні [2].

Книжні фразеологізми: фріговий листок, злий геній, холодна війна, чорні дні, стовповий шлях, розмінна монета, пробний камінь. Такі фрразеологізми $€$ іменниковими: іменник виконує роль граматично панівного слова.

Книжні фрразеологізми представлені в реченнях:

«Нині ия країна окупується Сполученими Штатами всупереч волі ї народу, під прикриттям фігового листка міжамериканських збройних сил» [1].

«Проте основним критерієм при такій оцінці, пробним каменем, на якому перевіряються цілі їх політики, їх дії, $\epsilon$ досягнення соціального розвитку всього людства і врятування його від ядерної війни» [1].

«Стовповий шлях до нерушимого миру - це загальне $і$ повне роззброєння» [1].

«Машина, що рухає "холодну війну,,, дещо уповільнила свій хід» [1].

«А скільки синів і дочок Украӥни... спалено в Майданеках, Освєнцімах ... які були створені злим генієм німецького імперіалізму і залишаться назавжди його вічною ганьбою!» [1]. «Вони відкрито заявляють про те, що ... частину загарбаної території арабських держав приєднати до Ізраїлю, а решту використати, як якусь розмінну монету» [1]

«... дії ізраїльських загарбників так нагадують чорні дні гітлерівської агресії [1].

Виділені книжні фрразеологізми є знаками, вони вимагають розшифровки, їхня оцінність ситуації є прихованою. Знак фіговий лист пов'язаний з текстом Біблії: перші люди усвідомили свою голизну і прикрилися. Цей знак викликає реакцію осуду, ситуація оцінюється так: США свідомо роблять свої справи, це 
їх вибір і політика. Фіговий лист - благопристойне прикриття ганебних вчинків: ми(США) ввели свою армію, що захищати цю землю.

Знак злий геній відносимо до вірувань стародавніх римлян: злий духохоронець штовхає людину на погані справи. Ситуація оцінюється як така, що людина не може робити таких звірячих вчинків, це була темна сила. Злий геній німецького імперіалізму - Адольф Гітлер. Цей знак викликає відчуття страху, безсилля людини перед непізнаним світом духів. Знак чорні дні відносимо до вірувань давніх людей про те, що існують особливі дні, коли нечиста сила може заподіяти велике лихо. Знову ситуація оцінюється так, що тільки нечиста сила може діяти таким чином. Дії ізраїльських загарбників порівнюються з діями гітлерівської агресії. Знову маємо відчуття страху, безсилля людини перед непізнаним світом духів. Знак стовповий шлях відносимо до часів, коли стовпами позначали верстви, створювався великий уторований проїзний шлях. Стовп - опора, у нашому тексті опорою будуть слова загальне і повне роззброєння. Тільки якщо опорою в політиці буде роззброєння, то можна прийти до миру. Цей знак пов'язаний з емоційним осмисленням значення миру і шляху його досягнення. Знак розмінна монета відносимо до часів появи грошових знаків. Відомо, що розмінні монети карбуються 3 дешевих матеріалів. Як цей зміст можна пов'язати з реченням в тексті виступу? Відповідь: частина арабських держав - це дешевий матеріал, життя людей в цих країнах - безцінь, якою можна пожертвувати заради досягнення своїх важливих цілей. Цей знак викликає реакцію осуду, оскільки життя - це найбільша цінність. І якщо деякі держави дозволяють собі оцінювати життя людей інших держав як безцінь, то це катастрофа, яку треба зупинити. Знак пробний камінь відносимо до історичної довідки про перші в світі монети. За допомогою чорного каменю відрізняли підробку: проводили монетою по каменю. Сліди від монети із чистого золота і від монети з домішками різнилися кольором. Маючи за основу речення з тексту виступу, за допомогою введеного знака маємо таке розуміння: сили і держави по-різному діють на міжнародній арені. Як оцінити їх дії? Основний критерій оцінювання (пробний камінь) досягнення соціального розвитку всього людства і врятування його від ядерної війни. Якщо дії сил і держав виконують це завдання, то оцінюємо їх як золоті (найрозумніші, найвартісніші). Знак стовп (опора) вказує на те, що людина завжди в своїх діях бере щось за опору, зо основу. Тільки якщо опорою в політиці буде роззброєння, то можна прийти до миру. Знак розмінна монета вказує, що життя людей - це не дешевий матеріал, яким можна жертвувати заради своїх інтересів. Знак пробний камінь пояснює, що основний критерій оцінювання дій держав - досягнення соціального розвитку всього людства і врятування його від ядерної війни.

Всі інші фразеологізми є розмовними. У дієслівних фрразеологізмах у ролі граматично панівного елемента виступає дієслово в неозначеній формі. Наприклад: підкорятися волі [1,c.37], йти в ногу [1,c.54], розривати кайдани [1,c.54], диктувати свою волю [1,c.55], задовольнити апетити [1,c.59], витримати перевірку часом [1,c.61], справляти поминки [1, с.63], робити ставку [1,c.64], демонструвати відчай [1,c.65], покласти край [1,c.74], зобразити невинною жертвою [1,c.74], обілити чорні діла [1,с.75], лити бруд [1,c.75], кидати виклик [1,c.76], стати ударною 
силою [1,c.76], забратися геть [1,c.77], покласти край [1,c.74], зітерти з пам'яті [1,с.79], бути втягнутим [1,с.77], скидати з рахівниці [1,c.24], працювати вхолосту $[1$, с.26], дивитися в очі $[1, c .35]$, бути вузлом суперечностей [1, с.34].

Репрезентовані сполуки вказують на дії, як-от: дії країн-агресорів; дії країн, що потерпають; дії ООН; дії СРСР.

Дії країн-агресорів: відмовляється дивитися в очі політичній дійсності;є вузлом суперечностей; диктують свою волю малим країнам; шукають способи задовольнити атомні апетити; справляють поминки по антинародному режиму; роблять ставку на політику сили; демонструють відчай і нездатність правильно зрозуміти співвідношення сил на світовій арені; міністр закордонних справ Ізраїлю намагався зобразити свою країну жертвою політики сусідніх арабських держав; міністр закордонних справ Ізраїлю, щоб обілити свої чорні діла, висунув проти СРСР фральшиві обвинувачення; агресор Ізраїль ллє бруд на борців за мир, кидає виклик всім миролюбним країнам, став ударною силою проти арабських держав.

Дії країн, що потерпають: розривають кайдани колоніалізму; змушені жити в стані війни (є втягнутими у вир війни); змушені нести важкий емоційний тягар (ніколи не зітерти з пам'яті горе, яке принесли німецькі окупанти).

Дії ООН: не мають права скидати з рахівниці небезпечні явища; повинні примусити колонізаторів підкорятися волі більшості народів; ООН потрібно йти в ногу з розвитком подій у світі; організація $\mathrm{OOH}$ витримала перевірку часом і забезпечує основу для погоджених дій держав в інтересах миру; ООН повинна покласти край кризі мирним шляхом; повинна примусити Ізраїль забратися геть з окупованих територій.

Дії СРСР: міністр закордонних справ СРСР А. А. Громико вказав на те, що механізм переговорів про загальне і повне роззброєння, тобто Комітет 18ти в ООН все ще працює вхолосту; проект резолюції Радянського Союзу ясно визначає заходи, які невідкладно повинні бути здійснені, щоб покласти край агресії і відновити мир у цьому районі земної кулі.

Викладене дозволяє зробити висновок про те, що репрезентовані в досліджуваних текстах фразеологізми образно й оцінно відображають світову політичну ситуацію.

\section{Список використаних джерел:}

1. Українська РСР на міжнародній арені: Збірник документів і матеріалів 1962-1970роки. (1977). К.: Політвидав України,

2. Фразеологічний словник української мови. (1999). К.: Наук. Думка, 


\section{$\Lambda \mathrm{O}$}

COLLECTION OF SCIENTIFIC PAPERS

WITH PROCEEDINGS OF THE INTERNATIONAL SCIENTIFIC AND PRACTICAL CONFERENCE

\section{«PROBLEMS AND PROSPECTS OF IMPLEMENTATION OF INNOVATIVE RESEARCH RESULTS»}

December 13, 2019 • Valletta, Republic of Malta

\section{VOLUME 3}

\section{English, Ukrainian, Russian and Chinese}

All papers have been reviewed

Organizing committee may not agree with the authors' point of view Authors are responsible for the correctness of the papers' text

Signed for publication 13.12.2019. Format 60×84/16

Offset Paper. The headset is Arial. Digital printing.

Conventionally printed sheets 6,86 .

Circulation: 100 copies.

Printed from the finished original layout.

Contact details of the organizing committee:

21037, Ukraine, Vinnytsia, Zodchykh str. 18, office 81

NGO European Scientific Platform

Tel.: +38098 1948380; +380981956755

E-mail: info@ukrlogos.in.ua

URL: www.ukrlogos.in.ua 